Portland State University

PDXScholar

7-2018

\title{
Community-Based Assessment of Smart Transportation Needs in the City of Portland
}

\author{
Aaron Golub \\ Portland State University, agolub@pdx.edu \\ Michael Serritella \\ Portland State University \\ Vivian Satterfield \\ OPAL Environmental Justice Oregon \\ Jai Singh \\ OPAL Environmental Justice Oregon
}

Follow this and additional works at: https://pdxscholar.library.pdx.edu/trec_reports

Part of the Transportation Commons, and the Urban Studies Commons Let us know how access to this document benefits you.

\section{Recommended Citation}

Golub, Aaron, Serritella, Michael, Satterfield, Vivian and Singh, Jai. Community-Based Assessment of Smart Transportation Needs in the City of Portland. NITC-RR1163. Portland OR: Transportation Research and Education Center (TREC), 2018. https://doi.org/10.15760/trec.204

This Report is brought to you for free and open access. It has been accepted for inclusion in TREC Final Reports by an authorized administrator of PDXScholar. Please contact us if we can make this document more accessible: pdxscholar@pdx.edu. 


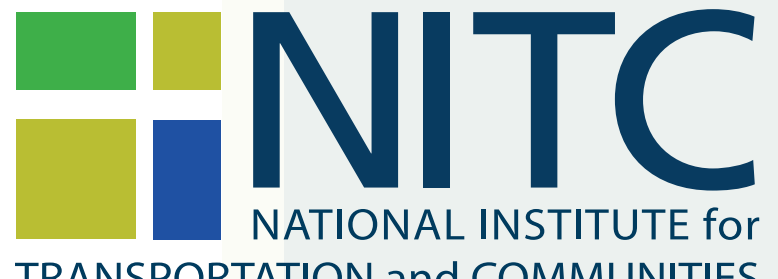

TRANSPORTATION and COMMUNITIES

FINAL REPORT

Community-Based Assessment of Smart Transportation Needs in the City of Portland

NITC-RR-1163 July 2018

NITC is a U.S. Department of Transportation national university transportation center.

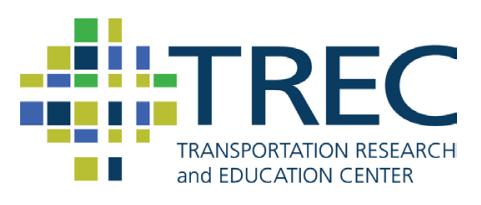





\title{
COMMUNITY-BASED ASSESSMENT OF SMART TRANSPORTATION NEEDS IN THE CITY OF PORTLAND
}

\section{FINAL REPORT NITC-RR-1163}

\author{
By \\ Aaron Golub and Michael Serritella \\ Portland State University \\ Vivian Satterfield and Jai Singh \\ OPAL Environmental Justice Oregon
}

for

National Institute for Transportation and Communities (NITC)

P.O. Box 751

Portland, OR 97207
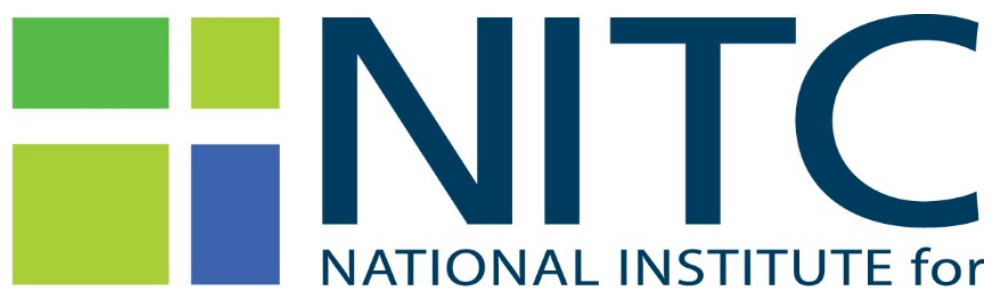

TRANSPORTATION and COMMUNITIES

July 2018 



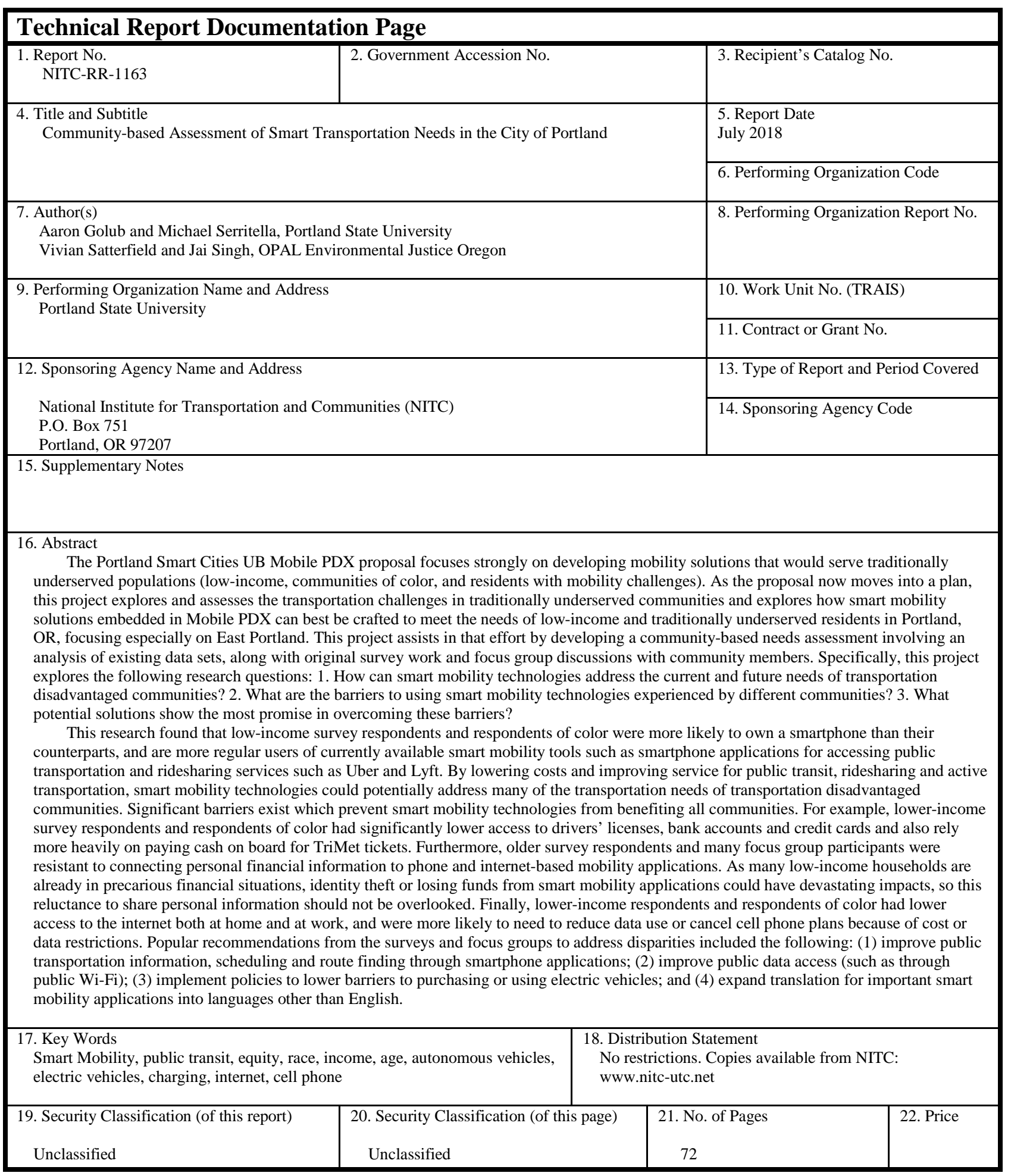




\section{ACKNOWLEDGEMENTS}

Aaron Golub would like to acknowledge partial support from Forth, The 11th Hour Project (a program of The Schmidt Family Foundation), the City of Portland, and the National Institute for Transportation and Communities (NITC) under grant number (1163).

\section{DISCLAIMER}

The contents of this report reflect the views of the authors, who are solely responsible for the facts and the accuracy of the material and information presented herein. This document is disseminated under the sponsorship of the U.S. Department of Transportation University Transportation Centers Program and Forth, The 11th Hour Project (a program of The Schmidt Family Foundation), and the City of Portland, in the interest of information exchange. The U.S. Government and Forth, The 11th Hour Project (a program of The Schmidt Family Foundation), and the City of Portland, assumes no liability for the contents or use thereof. The contents do not necessarily reflect the official views of the U.S. Government and Forth, The 11th Hour Project (a program of The Schmidt Family Foundation), and the City of Portland. This report does not constitute a standard, specification, or regulation.

\section{RECOMMENDED CITATION}

Golub, Aaron, Serritella, Michael, Satterfield, Vivian and Singh, Jai. Community-Based Assessment of Smart Transportation Needs in the City of Portland. NITC-RR1163. Portland, OR: Transportation Research and Education Center (TREC), 2018. 


\section{TABLE OF CONTENTS}

EXECUTIVE SUMMARY …………………………………………………………………………....

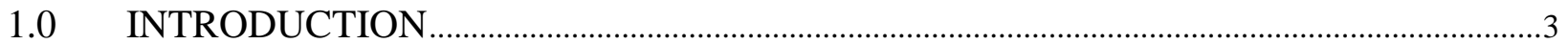

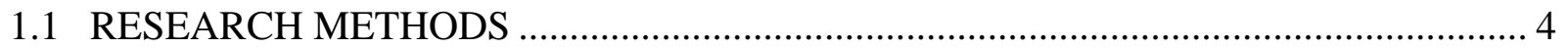

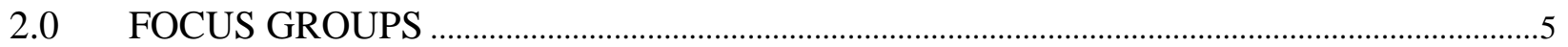

2.1 BASIC DESCRIPTION OF FOCUS GROUP ATTENDEES .................................... 5

2.2 FOCUS GROUP AND INTERVIEW RESULTS .................................................... 6

2.2.1 Improving access and use of apps: Education, training and public Wi-Fi............. 6

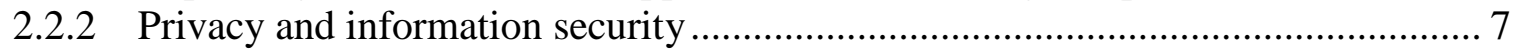

2.2.3 Access to documentation and financial services............................................. 7

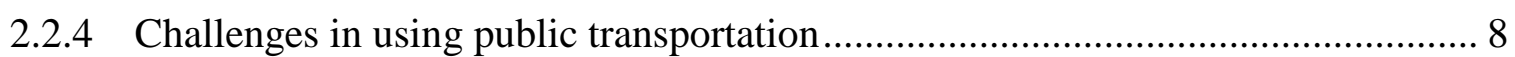

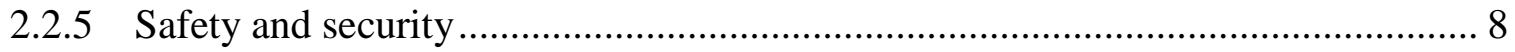

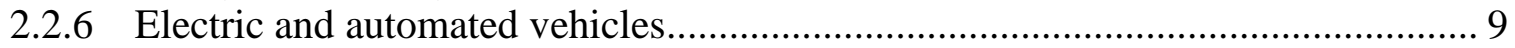

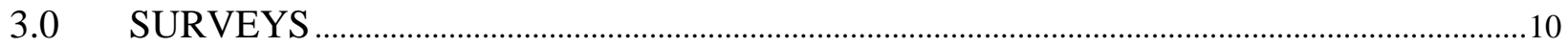

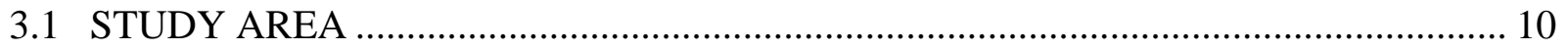

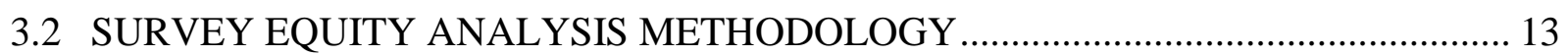

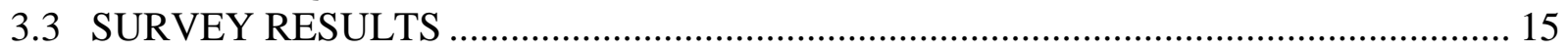

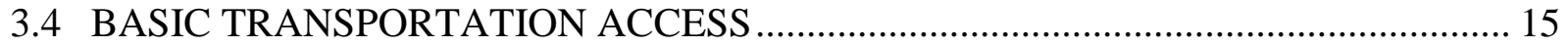

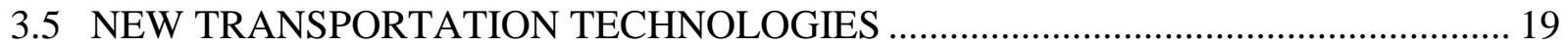

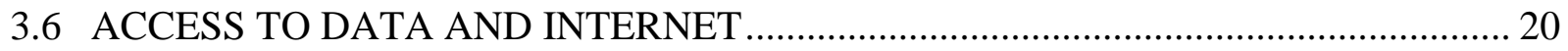

3.7 ACCESS TO BANKING AND CREDIT .................................................................. 22

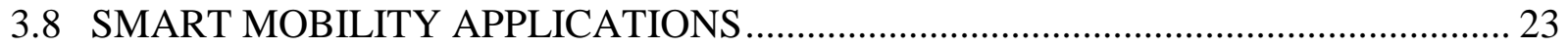

3.9 HOUSING AND ACCESS TO CHARGING FOR ELECTRIC VEHICLES ................. 25

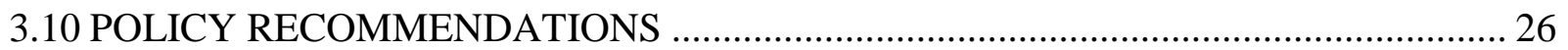

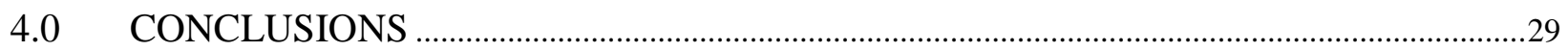

\section{APPENDICES}

APPENDIX A - SURVEY INSTRUMENT

APPENDIX B - DETAILED SURVEY QUESTION RESULTS

\section{LIST OF TABLES}

Table 1. Excerpts from intake surveys for the two focus groups............................6

Table 2. Estimates of household income for the study area and for the survey sample...........12

Table 3. Survey results: Basic transportation access (part 1) (For Yes/No questions, "overall” refer to the \% yes; "Generation, Income and Race/ethnicity” columns present comparisons between groups, with "ND” = no difference; differences which are problematic for social or

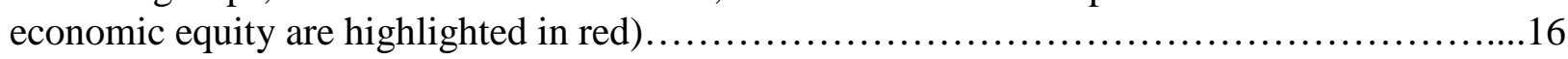
Table 4. Survey results: Basic transportation access (part 2) (For Yes/No questions, "overall” refer to the \% yes; “Generation, Income and Race/ethnicity” columns present comparisons 
between groups, with "ND” = no difference; differences which are problematic for social or

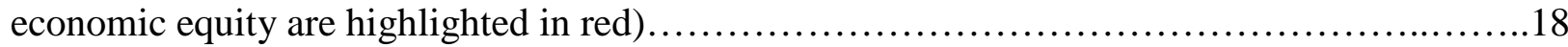

Table 5. Survey results: New transportation technologies (For Likert scale questions "overall” is the average, with $1=$ "Not at all" and 5 = "Very"; "Generation, Income and Race/ethnicity" columns present comparisons between groups, with "ND" = no difference)....................19 Table 6. Survey results: Access to data and internet (For Yes/No questions, “overall” refer to the \% yes; for frequency questions, "overall” represents an estimate of the number of times per month; "Generation, Income and Race/ethnicity" columns present comparisons between groups, with "ND” = no difference; differences which are problematic for social or economic equity are

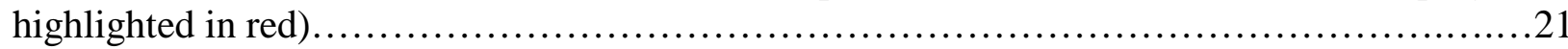
Table 7. Survey results: Access to banking and credit (For Yes/No questions, “overall” refer to the \% yes; for Likert scale questions "overall” is the average, with $1=$ "Not at all" and $5=$ "Very"; "Generation, Income and Race/ethnicity” columns present comparisons between groups, with "ND" = no difference, "NHW" = Non-Hispanic White and "POC" = Persons of color; differences which are problematic for social or economic equity are highlighted in red)........ 22 Table 8. Survey results: Smart mobility applications ("overall” represents an estimate of the number of times per month; "Generation, Income and Race/ethnicity” columns present comparisons between groups, with "ND" = no difference; differences which are problematic for

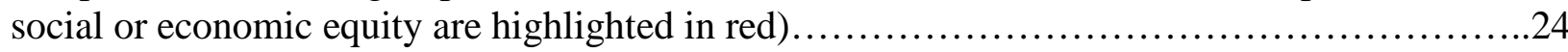
Table 9. Survey results: Housing and access to charging for electric vehicles ("Generation, Income and Race/ethnicity" columns present comparisons between groups, with "ND” = no difference; differences which are problematic for social or economic equity are highlighted in red).

Table 10. Ranking of policy preferences. The top four are bolded (half-point scores are ties). Table 11. Ranking of institutions preferred to convene public trainings. The top 3 are bolded (half-point scores are

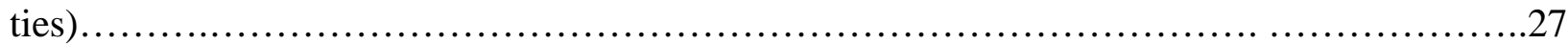

Table 12. Ranking of method preferred to deliver public trainings. The top choice is bolded

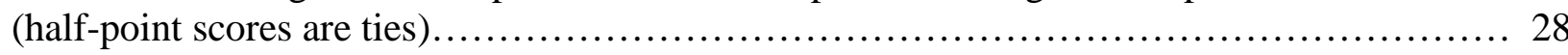
Table B1. How many cars, trucks, vans, or motorcycles are available in your household for you to use?.

Table B2. Of the cars available to you, do you lease, make payments, or own them?............... 41

Table B3. Do you have a driver's license? .......................................................................... 41

Table B4. Do you experience some kind of mobility-related impairment or disability? ............ 42

Table B5. Does your employer / school provide you a transit pass? ........................................ 42

Table B6. Does your employer / school provide free parking? ............................................... 43

Table B7. Does your employer / school provide secure onsite bicycle parking? ....................... 43

Table B8. Does your employer / school provide you a company vehicle?............................... 44

Table B9. Does your employer / school provide you access to an electric vehicle charger? ....... 44

Table B10. Does your employer / school provide you a Biketown subscription?...................... 45

Table B11. The most common mode of travel to work: Drive alone ....................................... 45

Table B12. The most common mode of travel to work: Carpool ............................................ 46

Table B13. The most common mode of travel to work: Public transportation........................... 46

Table B14. The most common mode of travel to work: Walked............................................ 47

Table B15. The most common mode of travel to work: Bicycle ........................................... 47

Table B16. The most common mode of travel to work: Ridesourcing (TNCs) ......................... 48 
Table B17. The most common mode of travel to work: Work at home ................................... 48

Table B18. How do you typically pay for the TriMet fare: On board ....................................... 49

Table B19. How do you typically pay for the TriMet fare: TriMet or retail store ..................... 49

Table B20. How do you typically pay for the TriMet fare: School or Work ............................ 50

Table B21. How do you typically pay for the TriMet fare: Online or Phone App ..................... 50

Table B22. How do you typically pay for the TriMet fare: Social service agency ..................... 51

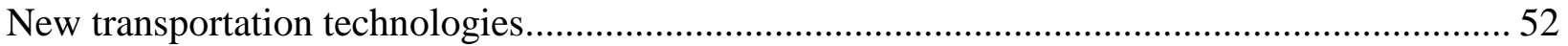

Table B23. How familiar are you with electric cars? ......................................................... 52

Table B24. How interested are you in owning an electric car? .............................................. 52

Table B25. How familiar are you with autonomous vehicles? ............................................. 53

Table B26. How comfortable would you be riding in an autonomous vehicle?......................... 53

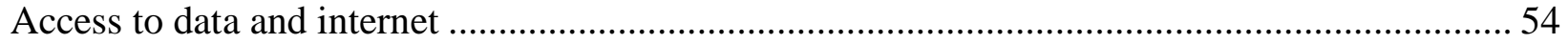

Table B27. How frequently do you use email and/or the internet? ......................................... 54

Table B28. At your home, do you have access to the internet? .............................................. 54

Table B29. If you work, at your workplace do you have access to the internet? ........................ 55

Table B30. If you have a cell phone, how frequently do you use public Wi-Fi in order to reduce

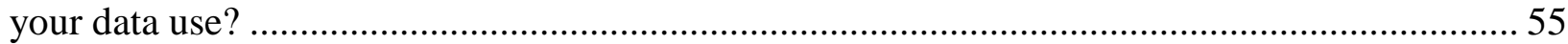

Table B31. Is your cell phone a smartphone?.................................................................. 56

Table B32. Have you ever had to cancel your cell phone service for a period of time because of

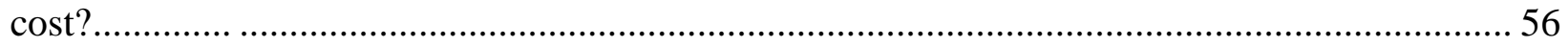

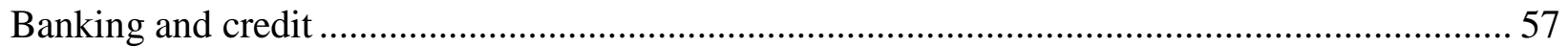

Table B33. Do you have a credit card or prepaid card account? ........................................... 57

Table B34. Do you have a checking or savings account?.................................................. 57

Table B35. How comfortable are you in linking your bank account or credit card to

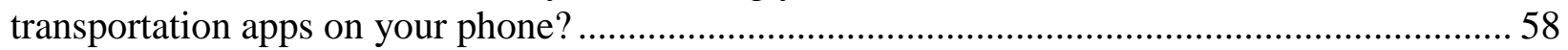

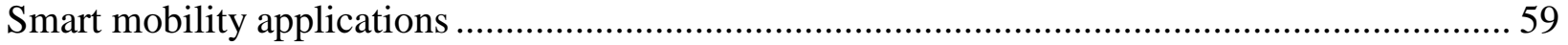

Table B36. If you have a smartphone, how often do you use your phone to get public

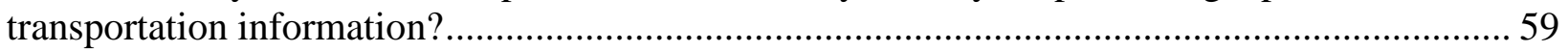

Table B37. If you have a smartphone, how often do you use your phone for navigation? .......... 59

Table B38. If you have a smartphone, how often do you use your phone to reserve a ridesourcing

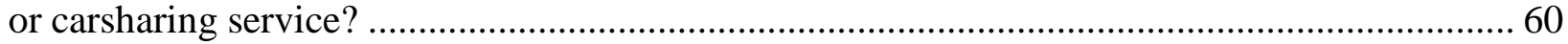

Table B39. If you have a smartphone, how often do you use your phone to use bikesharing?.....60

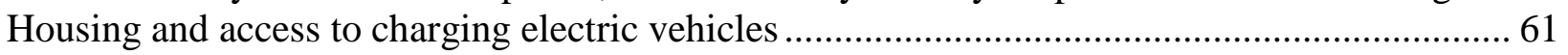

Table B40. What kind of housing structure do you live in? .................................................. 61

Table B41. At your home, would you be able to easily charge an electric vehicle (car or bicycle)?

.....................................................................

Table B42. Choose three policies (3) from the list below that you would like to see implemented:

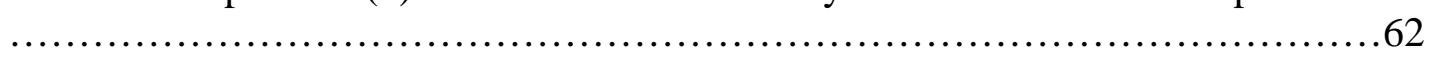

Table B43. Which of the following types of neighborhood institutions or places would you most trust to gain access to information about transportation services? (Select all that apply) ............ 62

Table B44. Which of the following types of media for receiving training would you prefer? .... 63

\section{LIST OF FIGURES}


Figure 1. Map of study area (red outline) and the locations of survey respondents by zip code Error! Bookmark not defined.

Figure 2. Age profiles for the study area and survey sample..........Error! Bookmark not defined. Figure 3. Race and ethnicity profiles for the study area and survey sample. ........................... 13 Figure 4. Breakdown of overall survey sample into demographic categories for use in equity analysis................................................................................Error! Bookmark not defined. 


\section{EXECUTIVE SUMMARY}

There is an active debate about the potential costs and benefits of emerging autonomous, electric, connected and shared vehicle and "transportation as a service" (ridesharing) technologies (classified here as "smart mobility"), especially in how they will serve communities already facing transportation disadvantages. The City of Portland and other local leaders, neighborhoods, and community organizations are working to implement a more socially just approach to smart mobility. Forth, The 11th Hour Project (a program of The Schmidt Family Foundation), the City of Portland, and PSU's National Institute for Transportation and Communities funded a collaborative research project between OPAL and PSU to carry out a community-based needs assessment of smart mobility. The assessment is a mixture of quantitative and qualitative research approaches. Two focus groups of community members from East Portland were convened. A survey was carried out with 308 total responses; respondents were heavily concentrated in East Portland. Some of the most important results are highlighted here, organized by the three research questions guiding this project.

Research question one: "How can smart mobility technologies address the current and future needs of transportation disadvantaged communities?" Lower vehicle ownership and incomes mean that transportation disadvantaged communities rely heavily on modes other than the private automobile. As a consequence, low-income survey respondents and respondents of color were more likely to own a smartphone than their counterparts, and are more regular users of currently available smart mobility tools such as smartphone applications for accessing public transportation and ridesharing services such as Uber and Lyft. Overall, it seems that by lowering costs and improving service for public transit, ridesharing and active transportation, smart mobility technologies could potentially address many of the transportation needs of transportation disadvantaged communities.

\section{Research question two: "What are the barriers to using smart mobility technologies} experienced by different communities?” Significant barriers exist which prevent smart mobility technologies from benefiting all communities. For example, lower-income survey respondents and respondents of color had significantly lower access to driver's licenses, bank accounts and credit cards and also rely more heavily on paying cash on board for TriMet tickets. Furthermore, older survey respondents and many focus group participants were resistant to connecting personal financial information to phone and internet-based mobility applications. As many lowincome households are already in precarious financial situations, identity theft or losing funds from smart mobility applications could have devastating impacts, so this reluctance to share personal information should not be overlooked. Finally, lower-income respondents and respondents of color had lower access to the internet both at home and at work, and were more likely to need to reduce data use or cancel cell phone plans because of cost or data restrictions. Since integrating payment systems and relying on internet and cell phone data to connect to mobile applications is a core feature of smart mobility systems, these disparities are a severe barrier to the equitable transition to smart mobility. In terms of using advanced personal mobility technologies like electric or autonomous vehicles, higher-income and white survey respondents 
were more familiar and more comfortable with these vehicles and had greater access to charging facilities, both at home and at work.

Research question three: "What potential solutions show the most promise in overcoming these barriers?" Popular recommendations from the surveys and focus groups included the following: (1) improve public transportation information, scheduling and route finding through smartphone applications; (2) improve public data access (such as through public Wi-Fi); (3) implement policies to lower barriers to purchasing or using electric vehicles; and (4) expand translation for important smart mobility applications into languages other than English. 


\subsection{INTRODUCTION}

In recent years, there has been an active and ongoing debate about the potential costs and benefits of emerging autonomous, electric, connected and shared mobility technologies - broadly classified here as "smart mobility" technologies. While there is a general consensus that such smart mobility technologies are inevitable elements of future urban mobility, competing visions exist for how this technology will actually integrate into our daily lives. One particular dimension of concern is how these new technologies will affect communities already facing transportation disadvantages, who are often marginalized within transportation planning or decision-making processes, who often don't benefit from investments in transportation (because they may live far from investments), and who often bear the burden of the cost of investment (such as environmental impacts). This project explores these overlapping issues - present-day transportation disadvantage and the potential for new investments and technologies to alleviate or exacerbate those existing disadvantages.

Innovation in the autonomous and electric vehicle landscape has been primarily driven by a consortium of private interests including automobile manufacturers (Ford, GM, Volvo, etc.), transportation network companies (TNCs) (Uber, Lyft, etc.), and major technology companies (Google, Apple, etc.). This project, however, is motivated by a public effort to anticipate the burdens and benefits of smart mobility technologies in order to guide public investments and regulations to improve outcomes for transportation disadvantaged communities. The City of Portland and other local leaders, neighborhoods, and community organizations have embarked on a process to intentionally design and implement a more socially just and sustainable approach to smart mobility. This project, funded by Forth, The 11th Hour Project (a program of The Schmidt Family Foundation), the City of Portland, and Portland State University's (PSU) National Institute for Transportation and Communities (NITC), was carried out through a collaboration between OPAL and PSU to assist in that process.

The Portland Smart Cities UB Mobile PDX proposal ${ }^{1}$ was developed in response to a major request for proposals from the United States Department of Transportation (USDOT). The City of Portland's original application was a national finalist, yet was not chosen by USDOT. The city and community have resolved to continue exploring this topic and this project is part of that effort. The original proposal focused strongly on developing mobility solutions that would serve traditionally underserved populations (low-income, communities of color, and residents with mobility challenges). As the proposal now moves into a plan, this project continues with that proposed community engagement process to explore and assess the transportation challenges in traditionally underserved communities, and explore how smart mobility solutions embedded in Mobile PDX can best be crafted to meet the needs of low-income and traditionally underserved residents in Portland, OR, focusing especially on East Portland. This project assists in that effort by developing a community-based needs assessment involving an analysis of existing data sets,

\footnotetext{
${ }^{1}$ https://www.portlandoregon.gov/transportation/69999
} 
along with original survey work and focus group discussions with community members. Specifically, this project explores the following research questions:

1. How can smart mobility technologies address the current and future needs of transportation disadvantaged communities?

2. What are the barriers to using smart mobility technologies experienced by different communities?

3. What potential solutions show the most promise in overcoming these barriers?

Significant existing research has been carried out recently in Portland-area communities about transportation challenges and disadvantages (e.g., Lubitow et al., 2016) ${ }^{2}$. That research illustrated how existing transit services deficiencies (network coverage, service time of day, travel times, headways and wait times, and costs); lack of sidewalk coverage and resulting safety concerns; and general transportation costs and distances create barriers to mobility for lowerincome communities and communities of color, especially those living on the edges of the region. This project will not revisit these questions, though discussions with communities always begin with understanding these challenges, using them as a starting-off point to discuss smart mobility innovations. To explore these questions this project took a mixed method approach utilizing both larger sample statistical analysis and smaller sample discussions and interviews.

In the first sections of this report, the project's research approach and methodologies are presented. The second section focuses on the focus groups and interviews, presenting details on how the focus groups were conducted and their results. The third section explores the larger sample survey, detailing the survey methods and study area, followed by results. The report concludes with a discussion of these results and their implications as the region moves forward on the smart mobility policies and investments. Additional details on our survey instrument and more detailed quantitative results from the large sample survey are both found in appendices.

\subsection{RESEARCH METHODS}

To answer the research questions listed above, it was decided that a mixture of both quantitative and qualitative research would be appropriate. Qualitative methods typically employed with research of this nature include interviews, of varying lengths, and focus groups. Such qualitative approaches can illuminate a wide range of issues and provide a deeper understanding of issues in a more efficient and direct manner. Quantitative methods include larger sample surveys which can reveal numerical and statistical patterns in data gathered from a large number of people. Combined, these methods can create an interwoven and layered understanding of the issues where richer and deeper stories from individuals and small groups can be corroborated or juxtaposed by data gathered from a larger sample of people. Also, this research relied on

\footnotetext{
${ }^{2}$ Lubitow, A. and Mahmoudi, D. (2016) Understanding Spatial Equity in Portland, Oregon. Portland State University Working paper.

https://www.pdx.edu/sociology/sites/www.pdx.edu.sociology/files/Spatial\%20Equity\%20Report.pdf
} 
qualitative information gathered through interviews and focus groups to inform the design of the larger sample survey instrument. By spending time in conversation with communities through the focus groups the research team could better understand the specific issues, terminologies and dimensions that needed to be included in an effective survey instrument. Therefore, this project began with focus groups and interviews which were followed by a larger sample survey administered both online and in person. The following sections present the results of the focus groups and then the larger sample survey.

\subsection{FOCUS GROUPS}

The primary goal of the focus groups was to engage a targeted group of participants to better understand how individuals identified as either belonging to a low-income community or as a person of color perceive the relative benefits and burdens of shared mobility within the local context of East Portland. The first focus group occurred on May 31, 2017, at Living Cully Plaza, a shared community and nonprofit space in the Cully neighborhood in Northeast Portland. Organized by OPAL Environmental Justice Oregon (OPAL), this focus group engaged 12 community members from Bus Riders Unite! to discuss the barriers and opportunities posed by smart mobility technologies for transit dependent populations in East Portland.

These discussions informed a re-scoping and revision of a nascent initial survey draft with an expanded set of questions addressing policy ideas and suggestions that surfaced from participants' input during the first focus group. These questions included one asking respondents to indicate priority policies that could be pursued by the City of Portland's Smart City initiative as well as the types of establishments (community center, neighborhood school, etc.) that they would prefer to offer mobility-related resources or trainings.

A second focus group was convened on July 13, 2017, at the Latino Network office in Rockwood, a neighborhood in Gresham sharing a similar racial and socioeconomic demographic profile as neighboring East Portland. While the first focus group consisted of a group of individuals more likely to be transit dependent, the second focus group with Latino Network was intended to represent the mobility challenges of East Portland and Gresham residents. By the nature of a pattern of automobile dependent and dispersed land use commonly found in the urbanized areas east of I-205, these participants were more likely to use automobiles on a regular basis.

Additional stakeholder interviews were performed with staff of two key community organizations, PAALF (Portland African-American leadership Forum) and NAYA (Native American Youth and Family Center).

\subsection{BASIC DESCRIPTION OF FOCUS GROUP ATTENDEES}

To get a general description of who attended the focus groups, attendees were asked to fill out an intake survey. Table 1 presents a few general descriptions of the groups. Overall, the Latino Network group consisted of wealthier drivers who rarely use public transportation, while the Bus 
Riders Unite! group had less access to private vehicles and used public transportation almost exclusively.

Table 1. Excerpts from intake surveys for the two focus groups

\begin{tabular}{ll|l}
\hline & Bus Riders Unite! (12 surveys) & Latino Network (9 surveys) \\
\hline Gender & Mostly female & All female \\
\hline Hispanic/Latino & Mostly Hispanic or Latino & All Hispanic or Latina \\
\hline Access to vehicles & Few have access & Most have access \\
\hline $\begin{array}{l}\text { Use of public } \\
\text { Transit }\end{array}$ & All take public transportation regularly & Few take public transportation regularly \\
\hline $\begin{array}{l}\text { Use of TNCs or } \\
\text { taxis }\end{array}$ & Rarely & Rarely \\
\hline $\begin{array}{l}\text { Access to electric } \\
\text { outlet for car } \\
\text { charging }\end{array}$ & No access & No access \\
\hline $\begin{array}{l}\text { Access to checking } \\
\text { or savings account }\end{array}$ & Few have access & Most have access \\
\hline $\begin{array}{l}\text { Access to credit } \\
\text { card }\end{array}$ & Few have access & Most have access \\
\hline
\end{tabular}

\subsection{FOCUS GROUP AND INTERVIEW RESULTS}

A great deal of qualitative information was collected during the focus group discussions, which lasted approximately two hours each. Additional qualitative comments were taken from the stakeholder interviews and from the open questions used in the larger sample surveys (to be presented in more detail in the next section). This summary identifies the major themes from these discussions.

\subsubsection{Improving access and use of apps: Education, training and public Wi-Fi}

Participants expressed a strong interest in opportunities for education and training on how to use technology - especially smartphone applications (apps) - to improve their access to mobility options. These applications need to be available in users' native languages and should be translated to reflect the diversity of languages spoken by residents in East Portland. To maximize effective use of the apps, participants indicated that they would be interested in attending inperson trainings at trusted neighborhood institutions such as neighborhood schools, libraries, and nonprofit organizations or at TriMet stations. For example, one participant stated: "I hope that technology is one day in my hands....Training would be important, and languages.” While another recounted: "I like the [transit] screens in downtown. I can read a little bit of English, but the time I was lost, I had to ask because the instructions were only in English. So not everyone can understand. In a situation that is unexpected like that, I don't know what the screen or the conductor is saying then it's frustrating. It makes you fearful...” The need for cheaper, or free, access to data through public Wi-Fi type services was also widely discussed. For instance, some participants talked about the difficulty of being out and about without a full data plan or charging stations. For example, one participant commented: 
"Sometimes my daughter uses the MAX, but her phone dies. I would really like this (wi-fi and mobile phone charging stations) because she has to ask folks to borrow their phone." Another noted the variability in cell coverage: “I don't necessarily have trouble affording cell phone, but the service in my neighborhood is terrible, so public wi-fi is very attractive."

\subsubsection{Privacy and information security}

Participants discussed multiple concerns and identified barriers to utilizing app-based technology. While the majority of participants had some form of access to the internet either through a computer or via their mobile device, many expressed concerns about privacy and security of mobility-related apps. Some expressed concerns related to privacy of personal mobility (ability of data to be use to track movement through location-based analytics).

Some participants also expressed major apprehensions about linking their bank accounts or credit cards to smartphone apps, citing concerns around security of their financial information (if phones were lost, stolen or hacked) and/or "glitches" in the system that would delete their credits/tickets. For example, a few representative statements from the focus groups included are worth reviewing here:

"I don't trust the banks, Trimet or electronic transactions."

"Online security is a joke"

"I don't like having financial information stored on my phone, I worry about it being lost or searched. I feel more secure doing on-line transactions from my home computer, and that's usually just as easy for me, so that's my preference."

“...Fortune 500 companies and the federal government can't keep data secure - why would we think Trimet is any better."

"I have had my identity stolen before so I'm weary of anything automated."

"I don't want it directly connected to my bank account in case there is some kind of security compromise; at least with a credit card, there is an opportunity for me to review and dispute charges."

There was a noticeable generational divide, however, between those with these concerns and younger participants. For example, one older participant stated: "Realistically my kids pay for everything by phone. Even at the store, they are connected to the card. I don't do that but young people do that, they buy everything by phones."

\subsubsection{Access to documentation and financial services}

Participants identified multiple institutional barriers related to licensure, necessary documentation, and access to formal banking and credit services. Many of the participants do not have a driver's license, but still drive as their mobility needs require flexibility and their 
transportation choices are limited. As a solution, some participants suggested that the state or city could issues "driving permits" which would allow them to legally use automobiles. Roughly a third of participants did not have a checking or savings account, or even if they did, were afraid to connect them to their phone apps. In the words of one participant: "I do have a bank account, but am afraid TriMet will use it and share it." Similarly, another respondent noted: "That would be great if we had bikeshare programs that actually work for folks where they live outside of the central city, but again, there is those concerns about needing a credit card or debit card in order to use it."

\subsubsection{Challenges in using public transportation}

Some participants shared transportation difficulties related to the time of day (specifically night access) and the amount of transfers and travel time required for their trips. Due to limited night or early morning service, participants were often required to drive to their destinations instead of using public transportation. For example, one survey respondent added:

"In the 6 years of [having] no car, while I enjoyed the experience of biking, transiting the city ... public transit just wasn't reliable enough. Now, we are buying a house further out (East Portland/ West Gresham) which the transit options lack even more, and the safety of riding is questionable at best. We will continue to use our personal vehicle to get around."

Participants also discussed logistical and schedule-related barriers related to their trip origins and destinations (often including multiple transfers and the resulting long trip lengths. For example, one participant noted: "The problem is the bus comes once an hour. What sense does it make to buy monthly pass if you can't use it. He has the monthly pass, but I am always giving him a ride because he misses the bus."

A few participants expressed difficulties using public transportation or rideshare systems with children, citing issues with crowding, the ability to store strollers or other supplies, and safety concerns. Concerns were raised around accessibility for those with mobility impairments, also citing crowding-related issues. Multiple participants expressed interest in being able to view, in real-time via a smartphone app, the level of crowding on a bus before it arrives as well as to be notified if their stop will be skipped due to overcrowding. In the words of one participant:

"If it would show you there are wheelchairs [on the bus]. If it would tell you how crowded the bus is. So theoretically the app can be connected with the bus and tell the bus if someone is waiting. The same when you're getting off the bus, so you'd be less likely to miss your stop."

\subsubsection{Safety and security}

Safety and security-related concerns emerged throughout the discussion in multiple contexts. Some participants related stories of being harassed by other passengers or police while using public transportation because of their race or ethnicity. Other participants raised safety concerns related to the quality of sidewalks and the design of streetscapes (especially the major arterials in East Portland),citing their fear of being injured by a car as a barrier to walking, biking, or accessing public transit stops. 


\subsubsection{Electric and automated vehicles}

Overall, the discussion about advanced vehicles including electric vehicles and automated vehicles was mixed. Some people saw potential in the technologies, while many were skeptical because of the need to focus public resources on improving public transportation or other more important current and pressing issues. Some felt that the focus on new technologies was a distraction from questions around access and where investments were made. The following comment embodies some of the concerns:

"I think we should definitely spend time talking about the concerns (of all these changes/incoming technology), as I mentioned before there's the safety concerns related to glitches in the system, and the fact that technology isn't the 'be-all, end-all.' Another concern is taking away living wage jobs. But also it seems the electric vehicle movement is perpetuating the same lifestyle that we have in our auto-based society..."

The discussion sometimes highlighted the fact that many low-income families benefit from the ability to do their own vehicle repair, or sometimes help friends and family members with their vehicles. Electric vehicles would change a lot of that. A comment on these issues was: "Car maintenance is a huge thing, I have always known family members, garages, shops, where I could get the work done cheap. EV is a whole different realm, in the sense of developing expertise in folks being able to have alternative options to fixing those cars."

Others recognize that there is a public benefit to advanced vehicle technologies but that it was important for the public to recognize that and for government to protect the public interest. For example, one commenter stated: "If we can treat electric driving vehicles the way we treat transit, as a public benefit, then I think there is a real case for it to be incredibly beneficial. To the extent that the future of electric vehicles, and the vision of it, is fully captured by industry, then I think there is real potential danger in that." Some highlighted the benefits of electric vehicles for local pollution and global climate change issues. For example, one survey respondent noted: "I would like to see all electric buses but also I would like to learn about the energy production process. I would like us to continue the conversations about transitioning to a solar/wind energy and clean hydroelectric dam infrastructure to be used to charge public transportation." 


\subsection{SURVEYS}

A survey was used to develop a broader profile of transportation issues beyond those raised in the qualitative focus groups. The larger sample in the survey also enables comparisons to be made between groups where significance can be verified using statistical tests. The survey was implemented both online and in person using identical instruments. In-person surveys were entered into a database and merged with the online responses. The survey instrument is included in Appendix A. The online survey was hosted on the OPAL website ${ }^{3}$ and was open for responses during August and September of 2017. The link was shared through social media and emails. The in-person surveys were performed at several public events and in one-on-one intercepts on transit vehicles (bus and MAX) in East Portland. A total of 308 surveys were received, 155 online and 153 in person.

As approximately seven in 10 residents living in Multnomah County identify as Non-Hispanic White, the racial demography of Multnomah County presents both a challenge and an opportunity in conducting outreach to communities of color. In order to effectively engage and represent the voices of people of color, targeted outreach at culturally specific community events was used. The study team visited working groups led by people of color, and conducted intercept surveys aboard transit vehicles and at transit hubs in East Portland. During the survey window a split of respondents of color $(\mathrm{n}=142)$ and those identifying as Non-Hispanic White $(\mathrm{n}=158)$ were surveyed. The following is a list of the events used for outreach (and their respective dates):

- Self Enhancement Inc. Parent Meeting (8/8/17)

- Jade Night Market - Portland Community College Southeast (8/19/17 \& 8/26/17)

- Festival Latino - Glenhaven Park (8/19/17)

- Oregon Walkways - Lents (8/6/17)

- Pan African Festival - (8/12/17)

- Community Alliance of Tenant Meeting - North Portland (8/17/2017)

- Intercept surveys on Bus/MAX (8/11, 8/28-9/2, 9/11, 9/12, 9/15, 9/21, 9/22)

\subsection{STUDY AREA}

This study was designed to illuminate the transportation challenges of lower-income East Portland communities and so the survey sampling strategy focused on those areas of the region. The use of an online survey, however, meant that it was harder to control exactly where survey participants lived. In the end, the sample included participants from all over Portland and

\footnotetext{
${ }^{3}$ http://www.opalpdx.org/2017/08/transportation-needs-assessment/
} 
Gresham, though still more were concentrated in East Portland as was desired. Figure 1 shows the numbers of survey respondents from different areas of the region (mapped by zip code). The red outline surrounds the study area and shows the heavier concentration of respondents from those areas.

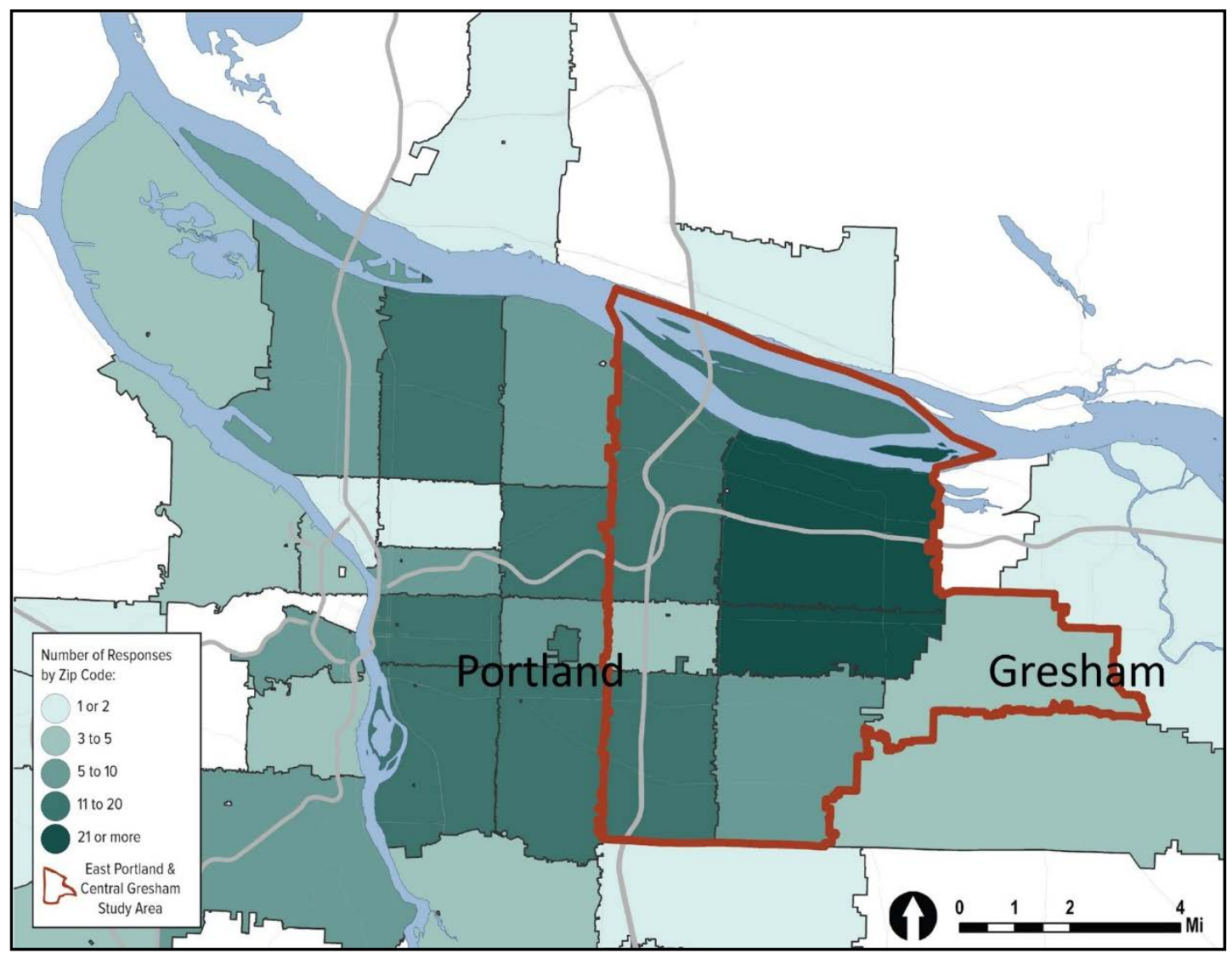

Figure 1. Map of study area (red outline) and the locations of survey respondents by zip code Source: Spatial Data - RLIS (accessed via PSU server)

Even though a significant number of survey participants were from outside of the desired study area, the demographic profiles of the study area and the survey sample are fairly similar. This is likely due to the social connections used to disseminate the survey; because it originated through OPAL members and friends, it likely still matched many of the same community profiles as found in East Portland. Table 2 compares household income measures for the study area and the survey sample. 
Table 2. Estimates of household income for the study area and for the survey sample

\begin{tabular}{l|l|l}
\hline & Study area & Survey sample \\
\hline Median household income & $\$ 43,700$ & $\sim \$ 35,000$ \\
\hline Poverty rate & $23.7 \%$ & $\sim 32 \%$ \\
\hline
\end{tabular}

Source: 5-YR American Community Survey (retrieved from Social Explorer) and survey sample

Figures 2 and 3 compare the age and race/ethnicity profiles for the study area and the survey sample. The survey sample is clearly overrepresentative of Millennial and Gen-X respondents, likely due to the internet-based distribution of the survey and the particular events in which the survey was administered in person. Similarly, the race and ethnicity profiles of the survey sample differs somewhat from that of the background study area. Significantly more Black or AfricanAmerican respondents appear in the survey compared to their proportion of the study area, while Asians and Hispanics are underrepresented. Overall, however, respondents of color are represented fairly similar to their proportion in the population.

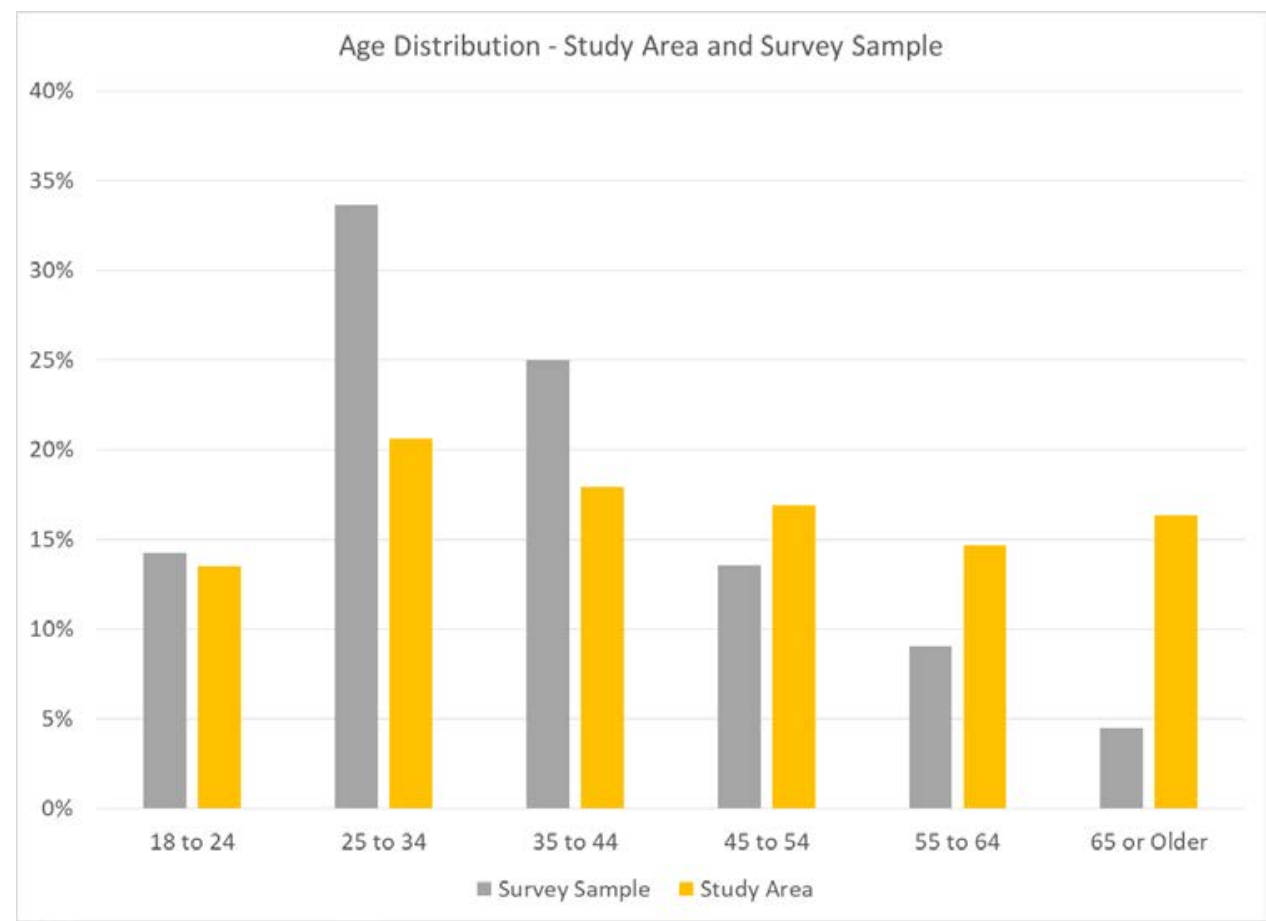

Figure 2. Age profiles for the study area and survey sample.

Sources: 5-YR ACS Community Survey (retrieved from Social Explorer) and survey sample 


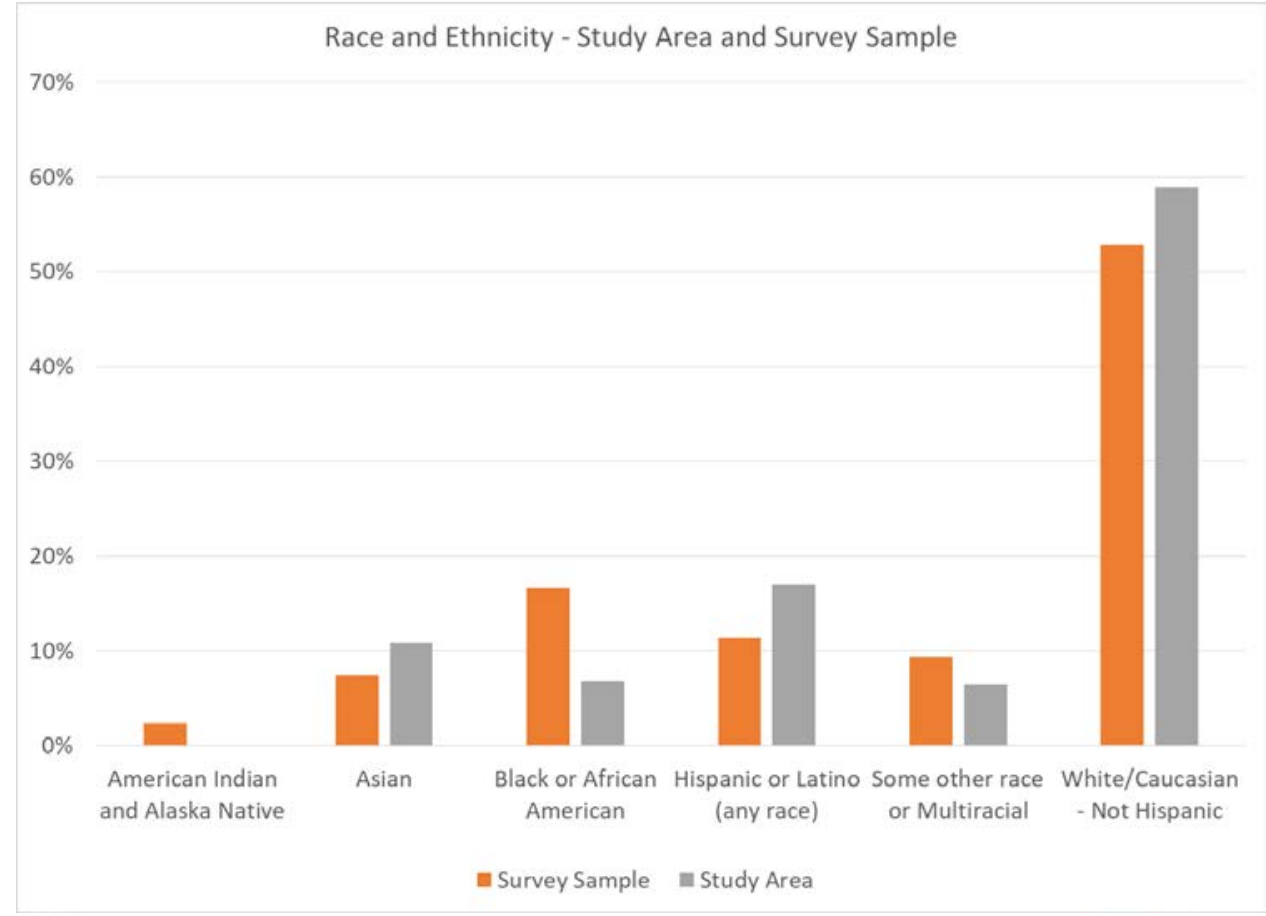

Figure 3. Race and ethnicity profiles for the study area and survey sample Source 5-YR ACS Community Survey (retrieved from Social Explorer) and survey sample

\subsection{SURVEY EQUITY ANALYSIS METHODOLOGY}

This analysis will look at the overall survey responses but will also attempt to make comparisons between groups to better understand the magnitude and significance of disparities. To design our subgroups for comparison, this project reviewed key demographic indicators often included in local and regional equity frameworks or analyses used in the Portland metropolitan area. In preparation for its 2018 Regional Transportation Plan, Metro, greater Portland's regional government, developed a framework to evaluate the equitable spatial distribution of regional transportation investments based on the relative proportion of low-income households, people of color, those with limited English proficiency, youth $(<18)$, and older adults $(65+) 4$. TriMet, the region's public transit service provider, and the Portland Bureau of Transportation (PBOT) employ a similar framework entitled Communities of Concern for assessing issues related to spatial equity - but also include ability status, access to affordable housing, a concentration of lower paying jobs, limited vehicle access, and limited access to services in developing their metric ${ }^{5}$. To be consistent with those approaches, this analysis breaks the survey sample along the following three demographic dimensions: race/ethnicity, household income, and age. Figure 5 shows how the survey responses fell along the three dimensions. The responses were split fairly evenly between respondents of color (herein POC) and White (herein Non-Hispanic White $(\mathrm{NHW})$ ) respondents, while there were more low-income respondents than high income. Looking at the survey responses broken down by age, Millennials represented half of the

${ }^{4}$ Metro - (Focused) Historically Marginalized Communities, 2016

${ }^{5}$ https://www.arcgis.com/home/item.html?id=a411529283e34385a853f41dc8742e29 
responses, with the remainder split between Baby Boomer (herein "Boomers") and Generation X (labeled "GenX” in Appendix B figures).

Grouping survey response data into these comparative sub-groups based upon these three key demographic dimensions allows the use of Chi-Square statistical tests to test whether the differences between groups are statistically significant. Thus, for all the comparisons made, differences can be tested for their statistical significance.
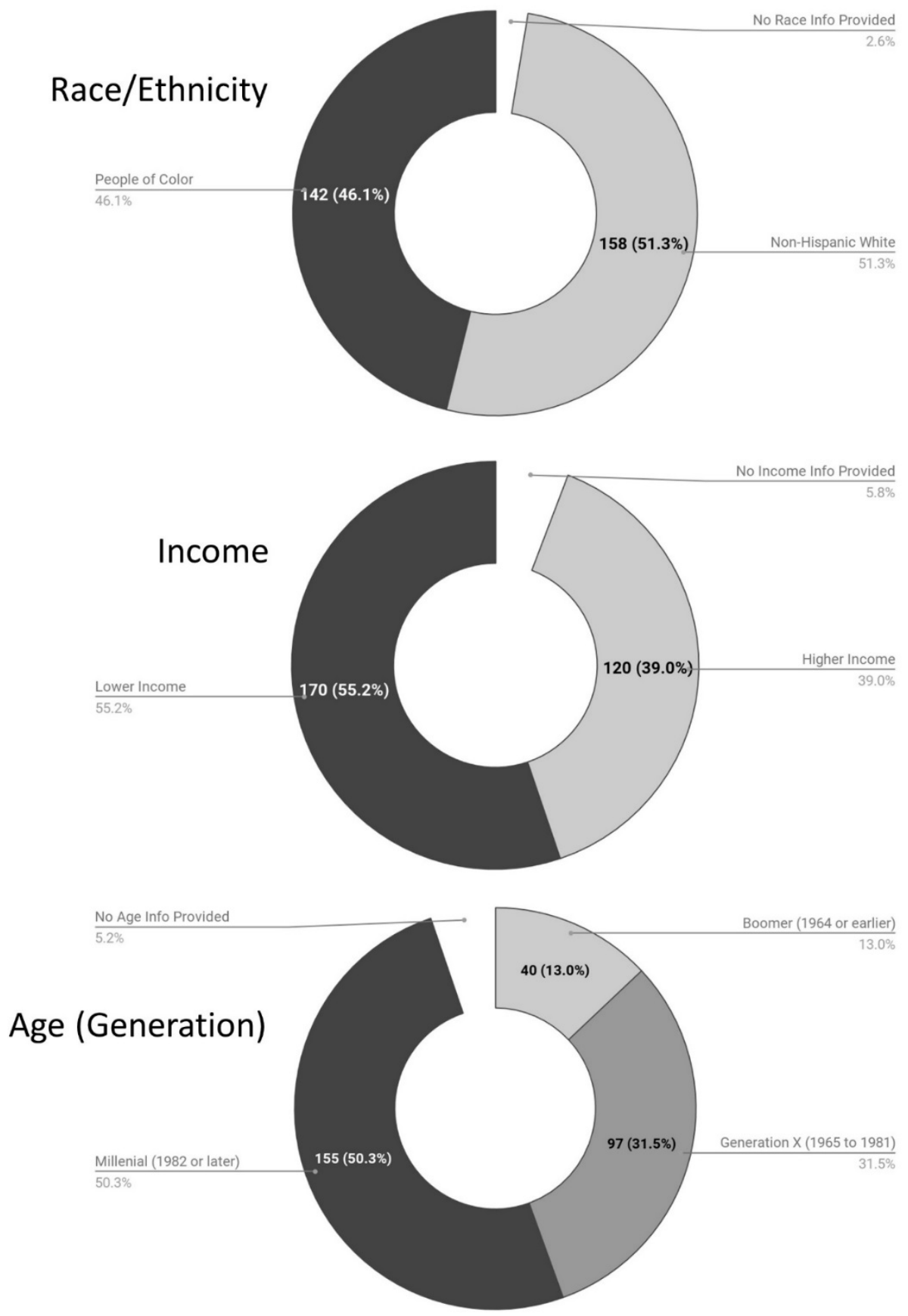

Figure 4. Breakdown of overall survey sample into demographic categories for use in equity analysis 


\subsection{SURVEY RESULTS}

The survey contains nearly 40 questions and the responses to most of those questions are analyzed here. The analysis is grouped into the following areas:

- Basic transportation access

- New transportation technologies

- Access to data and internet

- Access to banking and credit

- Smart mobility mobile applications

- Housing and access to charging for electric vehicles

- Policy recommendations

Because of the number of questions involved and the number of different options available for each, the detailed analysis of each question is not presented here. The detailed results, combined with the comparisons between our demographic groups, are presented for each question in Appendix B. In these sections, questions related to each area are presented in a summary table form. An "overall” result is presented alongside a statement about differences between our demographic groups. Occasionally, where significant, additional details or comparisons are included from the detailed data.

\subsection{BASIC TRANSPORTATION ACCESS}

This initial set of questions address access to vehicles, licensing and transportation benefits at school and work (Table 3). Overall, about $70 \%$ of respondents had access to a vehicle and $80 \%$ had a driver's license. Fewer, however, received transportation benefits at work or school. Transit passes, free parking and bicycle parking were the most common benefits, with around a quarter receiving each while very few people received the other benefits (company cars, electric vehicle charging and bikesharing subscriptions). Almost $10 \%$ of the respondents experienced some mobility challenges.

Driver's licensing rates varied significantly by race and income, with higher-income and White respondents having higher rates of licensing. This finding is not surprising considering the State of Oregon requirement of proof of legal residence to secure a driver's license. Among the other dimensions, higher-income respondents generally had better access to vehicles and transportation benefits at the work or school location. For some benefits, younger respondents had better access than older respondents. Older respondents reported significantly higher rates of mobility-related disabilities. 
A key takeaway here is that licensing rates and access to transportation benefits at work or school present significant existing equity challenges, especially along dimensions of class. Smart mobility investments, therefore, should understand these current inequities and work to address them. For example, higher levels of vehicle automation may not require driver's licenses and be a significant benefit to those who are legally or economically restricted from licensing. Similarly, addressing access to advanced mobility technologies through the workplace or school could be an area to address existing disparities.

Table 3. Survey results: Basic transportation access (part 1) (For Yes/No questions, “overall” refer to the \% yes; “Generation, Income and Race/ethnicity" columns present comparisons between groups, with "ND” = no difference; differences which are problematic for social or economic equity are highlighted in red).

\begin{tabular}{|c|c|c|c|c|}
\hline & Overall & Generation & Income & $\begin{array}{l}\text { Race/ } \\
\text { Ethnicity }\end{array}$ \\
\hline $\begin{array}{l}\text { How many cars, trucks, vans, or motorcycles are } \\
\text { available in your household for you to use? [Multiple } \\
\text { choice] }\end{array}$ & $\begin{array}{l}\text { Almost } 30 \% \text { had } \\
\text { no vehicle; } 40 \% \\
\text { had one vehicle }\end{array}$ & Older more & $\begin{array}{l}\text { Higher } \\
\text { more }\end{array}$ & ND \\
\hline $\begin{array}{l}\text { Of the cars available to you, do you lease, make } \\
\text { payments, or own them? [Multiple choice] }\end{array}$ & $\begin{array}{l}\text { More than half } \\
\text { own vehicles } \\
\text { outright }\end{array}$ & ND & $\begin{array}{l}\text { Higher } \\
\text { more } \\
\text { likely } \\
\text { own }\end{array}$ & ND \\
\hline Do you have a driver's license? [Y/N] & 80\% licensed & $\mathrm{ND}$ & $\begin{array}{l}\text { Higher } \\
\text { more (95 } \\
\text { vs } 70 \%)\end{array}$ & $\begin{array}{l}\text { NHW } \\
\text { more }(89 \\
\text { vs } 67 \%)\end{array}$ \\
\hline $\begin{array}{l}\text { Do you experience some kind of mobility-related } \\
\text { impairment or disability? [Y/N] }\end{array}$ & $9.5 \%$ & $\begin{array}{l}\text { Older more } \\
(18 \%)\end{array}$ & ND & ND \\
\hline $\begin{array}{l}\text { Does your employer / school provide you a transit } \\
\text { pass? [Y/N] }\end{array}$ & $28 \%$ & $\begin{array}{l}\text { Younger } \\
\text { more }\end{array}$ & $\begin{array}{l}\text { Higher } \\
\text { more }\end{array}$ & ND \\
\hline $\begin{array}{l}\text { Does your employer / school provide free parking? } \\
\text { [Y/N] }\end{array}$ & $23 \%$ & $\mathrm{ND}$ & $\begin{array}{l}\text { Higher } \\
\text { more }\end{array}$ & ND \\
\hline $\begin{array}{l}\text { Does your employer / school provide secure onsite } \\
\text { bicycle parking? [Y/N] }\end{array}$ & $26 \%$ & $\begin{array}{l}\text { Younger } \\
\text { more }\end{array}$ & $\begin{array}{l}\text { Higher } \\
\text { more }\end{array}$ & ND \\
\hline $\begin{array}{l}\text { Does your employer / school provide you a company } \\
\text { vehicle? [Y/N] }\end{array}$ & $2.5 \%$ & $\mathrm{ND}$ & ND & $\mathrm{ND}$ \\
\hline $\begin{array}{l}\text { Does your employer / school provide you access to an } \\
\text { electric vehicle charger? [Y/N] }\end{array}$ & $5 \%$ & $\mathrm{ND}$ & $\begin{array}{l}\text { Higher } \\
\text { more }\end{array}$ & $\begin{array}{l}\text { NHW } \\
\text { more }\end{array}$ \\
\hline $\begin{array}{l}\text { Does your employer / school provide you a Biketown } \\
\text { subscription? [Y/N] }\end{array}$ & $4 \%$ & $\begin{array}{l}\text { Younger } \\
\text { more }\end{array}$ & ND & ND \\
\hline
\end{tabular}


The second set of questions concerned modes of travel to work and methods of payment for TriMet tickets (Table 4). Overall, the survey respondents were extremely multimodal, with only around $27 \%$ driving alone to work, much lower than the metro area's $70 \% .{ }^{6}$ Similarly, rates of walking, bicycling and public transportation are many times higher than regional averages (not to mention United States averages, which are even lower). ${ }^{7}$ The implications of this current behavior are important - the survey respondents are already heavily engaged in "smart mobility" and as a group produce less climate impacts, endanger fewer people and produce less local environmental impacts than those in other parts of the region. Indeed, as the region makes investments and policy changes to improve smart mobility, it should be finding ways to reward and reinforce current behaviors in the study area.

There are significant equity issues in how transit fare is paid for with a significant number, around $40 \%$, who still rely on paying fares on board with cash. This poses a significant challenge to moving towards cashless mobility systems integrating with bank accounts and credit cards. This was a significant theme brought up in the qualitative research presented earlier and is similarly born out in these quantitative survey results. Significantly, however, more than onethird of respondents have moved to using online or phone applications to purchase fares. This is a positive development for the transition to smart mobility technologies. Cash dependence showed some equity issues along the dimensions of race/ethnicity and class, with lower-income and respondents of color indicating a higher reliance on cash payment on board. On the contrary, higher-income and White respondents showed more reliance on online and smartphone payments for fares. These equity issues should be addressed through smart mobility developments.

\footnotetext{
${ }^{6}$ Oregon Metro’s Regional Snapshots https://www.oregonmetro.gov/regional-snapshots

${ }^{7}$ Metro area regional averages of cycling to work were $\sim 2.5 \%$, public transit, $\sim 7 \%$, and walking, $\sim 3.5 \%$. (Oregon Metro's Regional Snapshots).
} 
Table 4. Survey results: Basic transportation access (part 2) (For Yes/No questions, “overall” refer to the \% yes; "Generation, Income and Race/ethnicity" columns present comparisons between groups, with "ND" = no difference; differences which are problematic for social or economic equity are highlighted in red).

\begin{tabular}{|c|c|c|c|c|}
\hline & Overall & Generation & Income & $\begin{array}{l}\text { Race/ } \\
\text { Ethnicity }\end{array}$ \\
\hline $\begin{array}{l}\text { The most common mode of travel to work: Drive alone } \\
\text { [Y/N] }\end{array}$ & $27.5 \%$ & ND & $\begin{array}{l}\text { Higher } \\
\text { more }\end{array}$ & ND \\
\hline $\begin{array}{l}\text { The most common mode of travel to work: Carpool } \\
\text { [Y/N] }\end{array}$ & $5 \%$ & ND & $\begin{array}{l}\text { Lower } \\
\text { more }\end{array}$ & ND \\
\hline $\begin{array}{l}\text { The most common mode of travel to work: Public } \\
\text { transportation [Y/N] }\end{array}$ & $36 \%$ & $\begin{array}{l}\text { Younger } \\
\text { more }\end{array}$ & $\begin{array}{l}\text { Lower } \\
\text { more }\end{array}$ & $\begin{array}{l}\text { POC } \\
\text { more }\end{array}$ \\
\hline $\begin{array}{l}\text { The most common mode of travel to work: Walked } \\
\text { [Y/N] }\end{array}$ & $12 \%$ & ND & $\begin{array}{l}\text { Lower } \\
\text { more }\end{array}$ & ND \\
\hline $\begin{array}{l}\text { The most common mode of travel to work: Bicycle } \\
\text { [Y/N] }\end{array}$ & $23 \%$ & $\begin{array}{l}\text { Younger } \\
\text { more }\end{array}$ & ND & ND \\
\hline $\begin{array}{l}\text { The most common mode of travel to work: } \\
\text { Ridesourcing (TNCs) [Y/N] }\end{array}$ & $2.2 \%$ & ND & $\begin{array}{l}\text { Lower } \\
\text { more }\end{array}$ & ND \\
\hline $\begin{array}{l}\text { The most common mode of travel to work: Work at } \\
\text { home [Y/N] }\end{array}$ & $6 \%$ & Older more & $\begin{array}{l}\text { Higher } \\
\text { more }\end{array}$ & $\begin{array}{l}\text { NHW } \\
\text { more }\end{array}$ \\
\hline $\begin{array}{l}\text { How do you typically pay for the TriMet fare: On board } \\
\text { [Y/N] }\end{array}$ & $42 \%$ & ND & $\begin{array}{l}\text { Lower } \\
\text { more (51 } \\
\text { vs 33\%) }\end{array}$ & $\begin{array}{l}\text { POC } \\
\text { more (49 } \\
\text { vs 37\%) }\end{array}$ \\
\hline $\begin{array}{l}\text { How do you typically pay for the TriMet fare: TriMet or } \\
\text { retail store [Y/N] }\end{array}$ & $10 \%$ & Older more & ND & ND \\
\hline $\begin{array}{l}\text { How do you typically pay for the TriMet fare: School or } \\
\text { Work [Y/N] }\end{array}$ & $15 \%$ & ND & $\begin{array}{l}\text { Higher } \\
\text { more }\end{array}$ & ND \\
\hline $\begin{array}{l}\text { How do you typically pay for the TriMet fare: Online or } \\
\text { Phone App [Y/N] }\end{array}$ & $35 \%$ & ND & $\begin{array}{l}\text { Higher } \\
\text { more (42 } \\
\text { vs 32\%) }\end{array}$ & $\begin{array}{l}\text { NHW } \\
\text { more (41 } \\
\text { vs 31\%) }\end{array}$ \\
\hline $\begin{array}{l}\text { How do you typically pay for the TriMet fare: Social } \\
\text { service agency [Y/N] }\end{array}$ & $3 \%$ & ND & $\begin{array}{l}\text { Low } \\
\text { more }\end{array}$ & ND \\
\hline
\end{tabular}




\subsection{NEW TRANSPORTATION TECHNOLOGIES}

Survey respondents were asked to comment on their familiarity and interest with electric vehicles and autonomous vehicles (Table 5). Admittedly, the survey instrument only included some basic information about these technologies and, therefore, these responses should be understood as reflecting a range of respondents' knowledge and assumptions about these technologies. Overall, the survey showed that respondents were more familiar and more interested in electric vehicles, which makes sense considering they are technologies already well deployed. Familiarity and comfort with autonomous vehicles was lower and split pretty evenly between high and lower levels of familiarity and comfort (see Tables B25 and B26, pages 60 to 61).

In terms of differences, higher-income respondents showed more familiarity with both electric and autonomous vehicles and stated they would be more comfortable with autonomous vehicles than lower-income respondents. White respondents were more familiar with both electric vehicles and autonomous vehicles than respondents of color. These differences should be noted for outreach and educational programs, which could be designed to address some of these disparities.

Table 5. Survey results: New transportation technologies (For Likert scale questions "overall” is the average, with $1=$ "Not at all" and 5 = "Very"; "Generation, Income and Race/ethnicity" columns present comparisons between groups, with "ND” = no difference).

\begin{tabular}{l|l|l|l|l}
\hline & Overall & Generation & Income & $\begin{array}{l}\text { Race/ } \\
\text { Ethnicity }\end{array}$ \\
\hline $\begin{array}{l}\text { How familiar are you with electric cars? } \\
\text { [Likert] }\end{array}$ & 3.3 & ND & Higher more & NHW more \\
\hline $\begin{array}{l}\text { How interested are you in owning an } \\
\text { electric car? [Likert] }\end{array}$ & 3.5 & ND & ND & ND \\
\hline $\begin{array}{l}\text { How familiar are you with autonomous } \\
\text { vehicles? [Likert] }\end{array}$ & 2.7 & ND & Higher more & NHW more \\
\hline $\begin{array}{l}\text { How comfortable would you be riding in } \\
\text { an autonomous vehicle? [Likert] }\end{array}$ & 2.6 & ND & Higher more & ND \\
\hline
\end{tabular}




\subsection{ACCESS TO DATA AND INTERNET}

The questions in this section address the issue of access to data, internet and smartphones (Table 6). Overall, access to internet was very high across all groups, with a small share, around $10 \%$, having no access to the internet at home or work. Similarly, smartphone use was very high at around $90 \%$ for most groups other than Boomers, where it was around $72 \%$. In contrast to the high rates of access to smartphones is the common need to use public Wi-Fi to reduce data use, and the significant number of respondents who had to cancel cell phone service because of cost. These results highlight the importance of access to inexpensive or free data via public Wi-Fi in the transition to smart mobility applications, especially as applications send and receive more information.

Although statistical analyses showed there are significant disparities among the generational, income and racial/ethnic groups, data and internet access across the groups was uniformly high. For example, although White respondents had much higher home access to the internet, 87\% of respondents of color had access. Policies or investment could be pinpointed to a small number of households to yield a large reduction in this disparity. While there were disparities in smartphone use, they were because lower-income and respondents of color had greater access than their counterparts. As mentioned above, only Boomers had markedly lower access to smartphones.

A significant and troubling disparity was in the area of cell data access. Lower-income and respondents of color were almost $40 \%$ more likely than average to have canceled cell service because of data plan limits and costs. And lower-income and younger respondents were more likely to need to connect to Wi-Fi to reduce data use (though age difference may reflect the higher intensity of data use among the younger respondents). This corresponds well with feedback from our focus group discussions where access to public Wi-Fi was seen as an important solution to improving the transition to smart mobility tools. 
Table 6. Survey results: Access to data and internet (For Yes/No questions, “overall” refer to the $\%$ yes; for frequency questions, "overall” represents an estimate of the number of times per month; "Generation, Income and Race/ethnicity" columns present comparisons between groups, with "ND” = no difference; differences which are problematic for social or economic equity are highlighted in red).

\begin{tabular}{|c|c|c|c|c|}
\hline & Overall & Generation & Income & $\begin{array}{l}\text { Race/ } \\
\text { Ethnicity }\end{array}$ \\
\hline $\begin{array}{l}\text { How frequently do you use email and/or } \\
\text { the internet? [Frequency, times per month] }\end{array}$ & 88.8 & Younger more & $\begin{array}{l}\text { Higher more } \\
(96 \text { vs } 84)\end{array}$ & $\begin{array}{l}\text { NHW more (93 } \\
\text { vs } 85)\end{array}$ \\
\hline $\begin{array}{l}\text { At your home, do you have access to the } \\
\text { internet? [Y/N] }\end{array}$ & $92 \%$ & ND & $\begin{array}{l}\text { Higher more } \\
(98 \text { vs } 88 \%)\end{array}$ & $\begin{array}{l}\text { NHW more (97 } \\
\text { vs } 87 \%)\end{array}$ \\
\hline $\begin{array}{l}\text { If you work, at your workplace, do you } \\
\text { have access to the internet? [Y/N] }\end{array}$ & $\begin{array}{l}79 \% \text { (out of } \\
84 \% \text { who } \\
\text { work) }\end{array}$ & Younger more & $\begin{array}{l}\text { Higher more } \\
\text { (99 vs 87\% of } \\
\text { those who } \\
\text { worked outside } \\
\text { the home) }\end{array}$ & ND \\
\hline Is your cell phone a smartphone? [Y/N] & $89 \%$ & $\begin{array}{l}\text { Younger more } \\
(94 \text { vs } 73 \%)\end{array}$ & Lower more & POC more \\
\hline $\begin{array}{l}\text { If you have a cell phone, how frequently } \\
\text { do you use public Wi-Fi in order to reduce } \\
\text { your data use? [Multiple Choice] }\end{array}$ & $\begin{array}{l}65 \% \text { connect } \\
\text { to Wi-Fi } \\
\text { whenever } \\
\text { possible or } \\
\text { occasionally }\end{array}$ & $\begin{array}{l}\text { Younger more } \\
\text { (74\% vs 67\% } \\
\text { for GenX and } \\
43 \% \text { for } \\
\text { Boomers) }\end{array}$ & $\begin{array}{l}\text { Lower more } \\
\text { (72 vs 63\%) }\end{array}$ & $\mathrm{ND}$ \\
\hline $\begin{array}{l}\text { Have you ever had to cancel your cell } \\
\text { phone service for a period of time because } \\
\text { of cost? [Y/N] }\end{array}$ & $25 \%$ & ND & $\begin{array}{l}\text { Lower more } \\
\text { (35 vs 12\%) }\end{array}$ & $\begin{array}{l}\text { POC more (33 } \\
\text { vs } 18 \%)\end{array}$ \\
\hline
\end{tabular}




\subsection{ACCESS TO BANKING AND CREDIT}

Reflecting on the discussions during the focus groups, is not surprising that there are significant disparities in access to banking and credit. Overall, access is high with $72 \%$ having access to credit and 90\% having access to banking services (Table 7). There were significant disparities, however, as access to credit and banking and comfort in linking personal financial information to phone applications was significantly higher for Whites and higher-income respondents. This result adds to the earlier concerns raised about the move to cashless payment systems through the internet or apps, concerning, for example the patterns found in how respondents paid for TriMet passes (Table 4, page 24). Significant efforts need to be made to offer cash payment methods, such as through systems like "Pay Near $\mathrm{Me}^{8}$." On the contrary, however, younger survey respondents were more comfortable with linking their financial information to mobility apps. Therefore, while older residents may have higher access to financial services, they may need additional training for them to become comfortable in using these applications.

Table 7. Survey results: Access to banking and credit (For Yes/No questions, "overall" refer to the \% yes; for Likert scale questions "overall" is the average, with $1=$ "Not at all" and $5=$ "Very"; "Generation, Income and Race/ethnicity" columns present comparisons between groups, with "ND" = no difference, "NHW" = Non-Hispanic White and "POC" = Persons of color; differences which are problematic for social or economic equity are highlighted in red).

\begin{tabular}{l|l|l|l|l}
\hline & Overall & Generation & Income & $\begin{array}{l}\text { Race/ } \\
\text { Ethnicity }\end{array}$ \\
\hline $\begin{array}{l}\text { Do you have a credit card or prepaid card } \\
\text { account? [Y/N] }\end{array}$ & $72 \%$ & Older more & $\begin{array}{l}\text { Higher more } \\
(90 \text { vs 60\%) }\end{array}$ & $\begin{array}{l}\text { NHW more (79 } \\
\text { vs 64\%) }\end{array}$ \\
\hline $\begin{array}{l}\text { Do you have a checking or savings } \\
\text { account? [Y/N] }\end{array}$ & $90 \%$ & ND & $\begin{array}{l}\text { Higher more } \\
(98 \text { vs 85\%) }\end{array}$ & $\begin{array}{l}\text { NHW more (95 } \\
\text { vs 84\%) }\end{array}$ \\
\hline $\begin{array}{l}\text { How comfortable are you in linking your } \\
\text { bank account or credit card to } \\
\text { transportation apps on your phone? }\end{array}$ & 3.3 & $\begin{array}{l}\text { Younger more } \\
\text { (3.6 for } \\
\text { Millennials, vs } \\
2.7 \text { for } \\
\text { Boomers) }\end{array}$ & $\begin{array}{l}\text { Higher more } \\
(3.7 \text { vs 3.1) }\end{array}$ & $\begin{array}{l}\text { NHW more (3.6 } \\
\text { vs 3) }\end{array}$ \\
\hline
\end{tabular}

\footnotetext{
8 "Pay Near Me" is system which allows one to pay bills such as utilities or credit card balances using cash at certain retailers. See http://paynearme.com/en/ for more information.
} 


\subsection{SMART MOBILITY APPLICATIONS}

This section of questions focused on the actual use of currently existing smart mobility applications, including public transportation information, navigation, TNCs and bikesharing (Table 8). The use of smartphone applications for public transit and navigation were quite high, with overall usage averaging around several times per week. The use of smartphone applications for TNCs and bikesharing were much lower at only a few days per month. Interestingly, there were fewer equity concerns as lower-income respondents and respondents of color used these applications similarly, and sometimes more than their counterparts. The one significant disparity in these results is that younger respondents use these applications more frequently by a significant margin (more than twice as much). This may be due to the higher access and use of private vehicles by respondents in the Boomer generation compared to Millennials; there is simply less need for these tools for the Boomer respondents. Considering, however, the lower comfort in connecting financial information to applications and the lower ownership of smartphones among Boomer respondents, this should still be a concern of smart mobility planning. A transition to smart mobility, which may render traditional single-occupant automobile travel more costly or difficult, will be more challenging for these Boomer respondents. 
Table 8. Survey results: Smart mobility applications (“overall” represents an estimate of the number of times per month; "Generation, Income and Race/ethnicity" columns present comparisons between groups, with "ND” = no difference; differences which are problematic for social or economic equity are highlighted in red).

\begin{tabular}{l|l|l|l|l}
\hline & Overall & Generation & Income & $\begin{array}{l}\text { Race/ } \\
\text { Ethnicity }\end{array}$ \\
\hline $\begin{array}{l}\text { If you have a smartphone, how often do } \\
\text { you use your phone to get public } \\
\text { transportation information? } \\
\text { [Frequency, Days per Month] }\end{array}$ & 13.4 & $\begin{array}{l}\text { Younger more } \\
(15.6 \text { for } \\
\text { Millennials, vs } \\
6.7 \text { for } \\
\text { Boomers })\end{array}$ & Lower more & POC more \\
\hline $\begin{array}{l}\text { If you have a smartphone, how often do } \\
\text { you use your phone for navigation? } \\
\text { [Frequency, Days per Month] }\end{array}$ & 15.8 & $\begin{array}{l}\text { Younger more } \\
(18 \text { for } \\
\text { Millennials, vs } \\
7.6 \text { for } \\
\text { Boomers })\end{array}$ & ND & ND \\
\hline $\begin{array}{l}\text { If you have a smartphone, how often do } \\
\text { you use your phone to reserve a } \\
\text { ridesourcing or carsharing service? } \\
\text { [Frequency, Days per Month] }\end{array}$ & 2.2 & $\begin{array}{l}\text { Younger more } \\
(2.4 \text { for } \\
\text { Millennials, vs } \\
1.4 \text { for } \\
\text { Boomers })\end{array}$ & Lower more & ND \\
\hline $\begin{array}{l}\text { If you have a smartphone, how often do } \\
\text { you use your phone to use bikesharing? } \\
\text { [Frequency, Days per Month] }\end{array}$ & 1.2 & ND & ND & ND \\
\hline
\end{tabular}




\subsection{HOUSING AND ACCESS TO CHARGING FOR ELECTRIC VEHICLES}

Housing type has a significant impact on access to convenient charging for electric vehicles. About half of the respondents live in a single-family home with the other half split between attached condominiums and townhomes or multiunit apartment buildings (Table 9). There were significant equity issues in housing type, with lower-income and respondents of color significantly more likely to live in multiunit apartment buildings. Similarly, younger respondents were more likely to live in multiunit apartment buildings compared to Boomer respondents. Not surprising, therefore, were the responses to questions about access to electric vehicle charging. Groups more likely living in multiunit buildings were those that expressed greater challenges in accessing charging facilities. Low-income respondents indicated they had easy access to charging at half the rate of their higher-income counterparts. Younger respondents and respondents of color indicated similar challenges. To further compound these disparities, higherincome and White respondents indicated better access to charging facilities at the workplace (Table 3, Page 22). The deployment of electric vehicles is an important intermediate step in the transition to autonomous shared vehicles and, therefore, policies and investments should attempt to address these disparities by offering more public locations for charging or assisting those living in multiunit buildings to access or install charging facilities.

Table 9. Survey results: Housing and access to charging for electric vehicles ("Generation, Income and Race/ethnicity” columns present comparisons between groups, with "ND” = no difference; differences which are problematic for social or economic equity are highlighted in red).

\begin{tabular}{|c|c|c|c|c|}
\hline & Overall & Generation & Income & $\begin{array}{l}\text { Race/ } \\
\text { Ethnicity }\end{array}$ \\
\hline $\begin{array}{l}\text { What kind of housing structure do } \\
\text { you live in? [Multiple choice] }\end{array}$ & $\begin{array}{l}32 \% \text { apartment; } \\
50 \% \text { single- } \\
\text { family home; } \\
18 \% \text { attached } \\
\text { townhome/condo }\end{array}$ & $\begin{array}{l}\text { Younger more } \\
\text { multi-family } \\
\text { (37\% of } \\
\text { Millennials vs } \\
23 \% \text { of } \\
\text { Boomers live in } \\
\text { apartments) }\end{array}$ & $\begin{array}{l}\text { Lower more } \\
\text { multi-family } \\
\text { (44 vs 19\% } \\
\text { live in } \\
\text { apartments) }\end{array}$ & $\begin{array}{l}\text { POC more } \\
\text { multi-family } \\
\text { (42 vs } 24 \% \text { live } \\
\text { in apartments) }\end{array}$ \\
\hline $\begin{array}{l}\text { At your home, would you be able to } \\
\text { easily charge an electric vehicle (car } \\
\text { or bicycle)? [Multiple choice] }\end{array}$ & $\begin{array}{l}30 \% \text { “yes” and } \\
20 \% \text { “with some } \\
\text { modification” }\end{array}$ & $\begin{array}{l}\text { Older easier } \\
\text { access ( } 45 \% \text { of } \\
\text { Boomers vs } \\
20 \% \text { of } \\
\text { Millennials have } \\
\text { access) }\end{array}$ & $\begin{array}{l}\text { Higher easier } \\
\text { access (42 vs } \\
21 \% \text { have } \\
\text { easy access) }\end{array}$ & $\begin{array}{l}\text { NHW easier } \\
\text { access ( } 37 \text { vs } \\
23 \% \text { have easy } \\
\text { access) }\end{array}$ \\
\hline
\end{tabular}




\subsection{POLICY RECOMMENDATIONS}

Table 10 shows the ranking of policy preferences from a list given in the survey, with the top references bolded. Public Wi-Fi and charging stations and improved real-time transportation information for public transit users were the two highest ranked overall. Interestingly, lowincome people, Millennials, and respondents of color preferred the public Wi-Fi as their top choice while older, wealthier and White respondents preferred the real-time communication as their top choice. Third and fourth choices included addressing language issues in smartphone applications and providing financial assistance for the purchase of electric vehicles. Lowerincome and respondents of color preferred addressing language issues, with the opposite result for higher-income respondents. Coming in a close fifth was interest in autonomous neighborhood shuttles to access transit stations. Boomers were especially interested in more electric vehicle charging stations, something many of the other groups ranked much lower.

These preferences mirror qualitative responses collected in both open-ended survey responses and comments made by focus group participants. Specifically, three of the five most popular policies expand the capacity of residents to use their smartphones as tools to access mobility services. The policies of expanding real-time communication between transit vehicles, investing in public Wi-Fi and charging stations for smartphones, and ensuring translation of mobility apps to multiple languages were named as specific barriers by focus group participants. These policies are implementable in the short term either individually or through a partnership between TriMet or the City of Portland. TriMet, already a well-established leader in open data sharing of transit information $^{9}$, is well positioned to take the lead on expanding the scope of real-time communication between its vehicles and its customers. TriMet could leverage its position to encourage developers who use their open data API to ensure their applications are accessible to all users, regardless of their preferred language.

\footnotetext{
${ }^{9}$ https://mobilitylab.org/2016/08/12/portland-open-data-techies/ // https://sf.streetsblog.org/2010/01/05/how-googleand-portlands-trimet-set-the-standard-for-open-transit-data/
} 
Table 10. Ranking of policy preferences. The top four are bolded (half-point scores are ties).

\begin{tabular}{l|l|l|l|l|l|l|l|l}
\hline Ranks & $\begin{array}{l}\text { Grand } \\
\text { Total }\end{array}$ & Boomer & GenX & Millennial & High & Low & NHW & POC \\
\hline $\begin{array}{l}\text { Smartphone applications for } \\
\text { transportation services translated } \\
\text { to languages other than English }\end{array}$ & $\mathbf{4}$ & 8 & 5 & $\mathbf{4}$ & 6.5 & $\mathbf{3}$ & $\mathbf{4}$ & $\mathbf{3}$ \\
\hline $\begin{array}{l}\text { Public Wi-Fi and charging stations } \\
\text { for smartphone/mobile technology }\end{array}$ & $\mathbf{2}$ & $\mathbf{2 . 5}$ & $\mathbf{2 . 5}$ & $\mathbf{1}$ & $\mathbf{1}$ & $\mathbf{1}$ & $\mathbf{2}$ & $\mathbf{1}$ \\
\hline $\begin{array}{l}\text { More electric vehicle charging } \\
\text { stations }\end{array}$ & 9 & $\mathbf{2 . 5}$ & 6.5 & 9 & 8 & 10 & 8 & 10 \\
\hline $\begin{array}{l}\text { Rebates or financing to help buy } \\
\text { clean electric vehicles }\end{array}$ & $\mathbf{3}$ & 5 & $\mathbf{2 . 5}$ & $\mathbf{3}$ & $\mathbf{2}$ & $\mathbf{4}$ & $\mathbf{3}$ & 4.5 \\
\hline $\begin{array}{l}\text { Expansion of the Biketown bike- } \\
\text { share program outside of central } \\
\text { neighborhoods }\end{array}$ & 6 & $\mathbf{4}$ & 8 & 6 & 5 & 6.5 & 5 & 8 \\
\hline $\begin{array}{l}\text { Expansion of carsharing services that } \\
\text { allow short-term vehicle rentals to } \\
\text { more neighborhoods }\end{array}$ & 7 & 7 & 6.5 & 7.5 & 6.5 & 6.5 & 7 & 9 \\
\hline $\begin{array}{l}\text { Self-driving neighborhood shuttles to } \\
\text { bring people to transit stops }\end{array}$ & 5 & 6 & $\mathbf{4}$ & 5 & $\mathbf{3}$ & 5 & 6 & 4.5 \\
\hline $\begin{array}{l}\text { Real time communication between } \\
\text { buses and riders about crowding, } \\
\text { arrival time, etc. }\end{array}$ & $\mathbf{1}$ & $\mathbf{1}$ & $\mathbf{1}$ & $\mathbf{2}$ & $\mathbf{1}$ & $\mathbf{2}$ & $\mathbf{1}$ & $\mathbf{2}$ \\
\hline $\begin{array}{l}\text { More public outreach and education } \\
\text { around smartphone applications for } \\
\text { transportation services }\end{array}$ & 10 & 10 & 10 & 10 & 10 & 9 & 10 & 7 \\
\hline $\begin{array}{l}\text { More public outreach and education } \\
\text { about different mobility options like } \\
\text { carsharing, Biketown, etc. }\end{array}$ & 8 & 9 & 9 & 7.5 & 9 & 8 & 9 & 6 \\
\hline
\end{tabular}

Respondents were asked to give their preferences about how they would want to receive any trainings or information about smart mobility applications (Table 11). Those rankings highlighted public libraries, TriMet facilities and, in third place, community centers as the preferred locations and institutions to convene such activities. It would be quite easy for the City of Portland to collaborate with regional service providers such as TriMet or the Multnomah County Library to develop outreach and educational programs about smart mobility options.

Table 11. Ranking of institutions preferred to convene public trainings. The top 3 are bolded (half-point scores are ties).

\begin{tabular}{l|l|l|l|l|l|l|l|l}
\hline Ranks & $\begin{array}{l}\text { Grand } \\
\text { Total }\end{array}$ & Boomer & GenX & Millennial & High & Low & NHW & POC \\
\hline Church or Place of Worship & 7 & 7 & 7 & 7 & 7 & 7 & 7 & 7 \\
\hline Community Center & $\mathbf{3}$ & $\mathbf{2}$ & $\mathbf{3}$ & $\mathbf{3}$ & $\mathbf{3}$ & $\mathbf{3}$ & $\mathbf{3}$ & $\mathbf{2 . 5}$ \\
\hline Neighborhood Public School & 5 & 5 & 4.5 & 5 & 5 & 5 & 5 & 5.5 \\
\hline Public Libraries & $\mathbf{1 . 5}$ & $\mathbf{1}$ & $\mathbf{1}$ & $\mathbf{2}$ & $\mathbf{1}$ & $\mathbf{1}$ & $\mathbf{1}$ & $\mathbf{2 . 5}$ \\
\hline TriMet Transit Station & $\mathbf{1 . 5}$ & $\mathbf{3}$ & $\mathbf{2}$ & $\mathbf{1}$ & $\mathbf{2}$ & $\mathbf{2}$ & $\mathbf{2}$ & $\mathbf{1}$ \\
\hline $\begin{array}{l}\text { Grocery Store or Market (i.e. Fred } \\
\text { Meyer, Plaid Pantry) }\end{array}$ & 6 & 6 & 6 & 6 & 6 & 6 & 6 & 5.5 \\
\hline
\end{tabular}




\begin{tabular}{l|l|l|l|l|l|l|l|l|}
\hline $\begin{array}{l}\text { Non-Profit Organization (i.e. } \\
\text { IRCO, Oregon Food Bank, } \\
\text { Hacienda CDC, etc.) }\end{array}$ & 4 & 4 & 4.5 & 4 & 4 & 4 & 4 & 4 \\
\hline
\end{tabular}

Finally, respondents were asked about how they would want to receive such trainings and the clear preference was for online materials (Table 12). This result may be related to the fact that half of surveys were carried out online, but the high rate of access to the internet and cell service indicated this may be the best option nonetheless. Considering the cost and logistical challenge of in-person trainings, those could be carried out in a more limited fashion, perhaps focusing on older residents who did respond that they preferred printed materials.

Table 12. Ranking of method preferred to deliver public trainings. The top choice is bolded (half-point scores are ties).

\begin{tabular}{l|l|l|l|l|l|l|l|l}
\hline Ranks & $\begin{array}{l}\text { Grand } \\
\text { Total }\end{array}$ & Boomer & GenX & Millennial & High & Low & NHW & POC \\
\hline $\begin{array}{l}\text { As an in-person training with a } \\
\text { TriMet or City of Portland } \\
\text { employee }\end{array}$ & 3 & 3 & 3 & 3 & 3 & 2.5 & 3 & 2 \\
\hline $\begin{array}{l}\text { Through a web-based video (i.e., } \\
\text { a YouTube training) }\end{array}$ & $\mathbf{1}$ & 2 & $\mathbf{1}$ & $\mathbf{1}$ & $\mathbf{1}$ & $\mathbf{1}$ & $\mathbf{1}$ & $\mathbf{1}$ \\
\hline $\begin{array}{l}\text { Through a printed booklet or } \\
\text { informational flyer }\end{array}$ & 2 & $\mathbf{1}$ & 2 & 2 & 2 & 2.5 & 2 & 3 \\
\hline
\end{tabular}




\subsection{CONCLUSIONS}

To organize the key overall conclusions from these results, it may be easiest to return to the original research questions guiding this study. The first question was: "How can smart mobility technologies address the current and future needs of transportation disadvantaged communities?"

Various results from this study respond to this question. One of the most interesting takeaways was how the low-income and respondents of color (and others, though to a lesser extent) are extremely multimodal in their travel behavior. Lower vehicle ownership and lower incomes, on average, meant that the transportation disadvantaged communities rely heavily on modes other than the private automobile. As far as smart mobility technologies can facilitate, and make cheaper and more convenient, alternatives to the private automobile it is clear that smart mobility technologies have the potential to address many of the current and future transportation needs of transportation disadvantaged communities. Indeed, low-income respondents and respondents of color are not only more multimodal, but more regular users of currently available mobility tools such as smartphone applications for accessing public transportation and ridesharing services such as Uber and Lyft. Furthermore, low-income respondents and respondents of color were greater users of smartphones compared to their counterparts. Considering the interest in better access to real-time public transportation information, it seems that smart mobility technologies are particularly poised to address those needs.

The second research question guiding this work was the following: "What are the barriers to using smart mobility technologies experienced by different communities?” Many barriers were highlighted here. A first significant barrier is the disparity in access to driver's licenses, bank accounts and credit cards among lower-income respondents and respondents of color, as well as the reluctance by older respondents to connect personal financial information to mobility applications. Since integrating convenient payment systems, like credit cards, into the transportation applications is a core feature of smart mobility systems, this disparity is a severe barrier to the equitable transition to smart mobility. This disparity also is evident in how lowincome respondents and respondents of color rely more heavily on paying cash on board for transit fares. While there are some ways to address this problem, they tend to be less than ideal (such as paying in cash at retail locations). Much like there were programs to assist low-income households in owning automobiles, there needs to be an effort made to create secure means of using cash in these emerging systems. Additionally, over time as these applications advance and their security improves, older residents will more be comfortable in linking their information.

This discomfort with sharing personal financial information should not be underestimated by planners and city staff. As many low-income households are already in precarious financial situations, identity theft or losing funds from online or smartphone accounts could have devastating impacts. Higher-income households can often absorb these losses or use banks or credit card companies which forgive fraudulent activity when it happens against their accounts. These insurances are not shared by everyone, so the idea of information security should be taken quite seriously. This concern was certainly expressed many times during the focus groups and in open-ended survey responses. 
Another significant barrier is the access to data and the internet. Higher-income and White respondents had greater access to the internet both at home and at work, and were less likely to need to reduce data use or cancel cell plans because of cost or data restrictions. As emerging smart mobility tools will rely on smartphones and larger data transmissions, these issues are especially important. Indeed, public Wi-Fi was the highest-ranked policy recommendation among the 13 options offered for selection in the survey and was mentioned numerous times during the focus groups.

Another interesting disparity was the differences in interest in electric and autonomous vehicles, where higher-income and White respondents were more familiar and more comfortable with these vehicles. Furthermore, higher-income and White respondents had greater access to charging facilities both at home and at work and lived in structures which facilitate adding charging facilities. If electric vehicles are to be more widely used, then these barriers should be addressed. Indeed, assisting buyers with financing to purchase electric vehicles was the third-ranked policy proposal, illustrating its importance among a broad set of the survey respondents.

The third research question guiding this project was: "What potential solutions show the most promise in overcoming these barriers?" The overall highest ranked recommendation from the surveys was to facilitate public transportation information, scheduling and route finding through improved real-time communication to users through smart applications. How this improves on current tools available is an open question but for many public transit users facing crowding on certain routes or needing additional room for strollers or wheelchairs, better information about in-vehicle conditions and crowding were common requests. It seems very much within the purview of smart mobility applications to provide these improved tools. Based on the survey responses but also the extensive comments received through the focus groups and open-ended survey questions, it was clear that more public support for data access (such as though public Wi-Fi or information kiosks) was also a top priority. Also, high priorities were to lower barriers to purchasing or using electric vehicles and expanding translation for important transportation applications into languages other than English. The latter recommendation was very common in the focus group discussions and would integrate clearly with the public mission of a publicly managed smart mobility platform with the goal of providing universal access and usability. While respondents preferred to receive trainings using online methods, if trainings or outreach were to occur they preferred public spaces such as community centers, TriMet facilities, or public libraries (in contrast with individual organizations or churches).

Overall, this research points to some significant and positive contributions that smart mobility technologies could have to improve the mobility of transportation disadvantaged communities. As smart mobility technologies facilitate mobility without the private automobile, this can improve transportation systems already used by the transportation disadvantaged by improving service or lowering costs. Still, there are formidable barriers, especially in access to credit, banking, and affordable cell and internet service, which could leave many people behind. Just as the freeway, the suburb and the private automobile left many behind, as few planners predicted any negative impacts, we can do better. This research project is part of an effort of anticipatory governance: Understanding barriers and posing questions as the technologies are being developed, and not after. This project was not meant to design solutions but hopefully presents enough information to clarify and prioritize next steps and the role of the public in 
improving the prospect for smart mobility to positively impact the lives of the transportation disadvantaged in our community. 


\section{APPENDIX A - SURVEY INSTRUMENT}
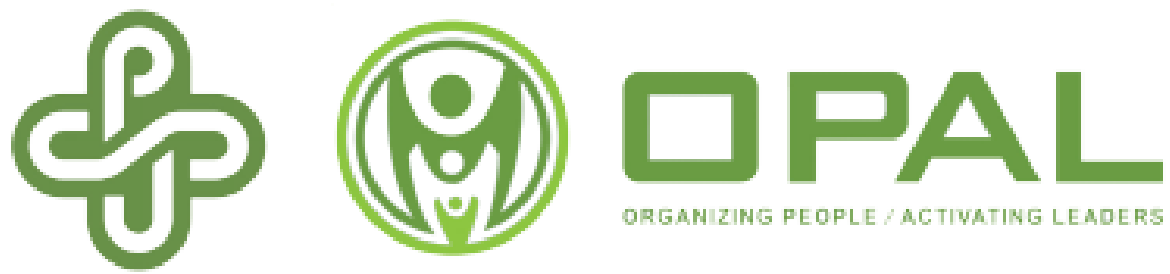

\section{COMMUNITY-BASED ASSESSMENT OF TRANSPORTATION NEEDS}

The following information is being collected by a group of researchers from OPAL Environmental Justice Oregon and Portland State University. We are interested in learning about your transportation choices, needs and challenges in order to provide recommendations that will help ensure the transportation system of the future works for everyone. Your responses are strictly confidential (we won't know who you are!), and will be compiled with many other responses in summary form. Feel free to skip any questions you don't wish to answer. This survey is estimated to take 10 to 15 minutes to complete.

\section{TRANSPORTATION QUESTIONS}

1) How many vehicles (cars, trucks, vans, or motorcycles) are available to you to use? (Privately owned by members of your household; not car-share).

2) Of the vehicles available to you, do you lease, make payments, or own them? (Select all that apply)

$\square^{\prime \prime}$ l lease my vehicle

$\square^{2}$ I own, but make monthly payments

$\square^{3}$ I own my vehicle

3) Do you have a driver's license?

$\square$ YesI $\mathrm{No}$

4) Does your employer / school provide you (Please check all that apply):

$\square^{1}$ A transit pass or allowance

$\square^{2}$ Free parking for your car, truck, or van

$\square^{3}$ Onsite secure bicycle parking

$\square^{4}$ Access to a company car, truck, or van

$\square^{5}$ Access to an electric vehicle charger

$\square^{6}$ Biketown subscription or discount

$\square^{7}$ None of the above

$\square^{8}$ Other: 
5) What is the most common mode of travel you use to get to work?

$\square^{1}$ Car, truck, or van -- drive alone

$\square^{2}$ Car, truck, or van -- carpool

$\square^{3}$ Public transportation (excluding taxicab)

$\square^{4}$ Walked

$\square^{5}$ Bicycle

$\square^{6}$ Rideshare (Uber, Lyft) or Taxi

$\square^{7}$ I work at home

$\square^{8}$ I don't work

$\square^{9}$ Other:

6) If you use Tri-Met (bus, MAX, Lift, Streetcar, WES), how do you typically pay for the fare? (Please check all that apply)

$\square^{\prime}$ On board bus or streetcar or at a Trimet station

$\square^{2}$ Retail Store

$\square^{3}$ School/Work

$\square^{4}$ Online/Phone App

$\square^{5}$ Social Service Agency

$\square^{6}$ N/A - I do not or only rarely use public transportation

$\square^{7}$ Other:

7) Electric cars run on batteries that are charged up with electricty, instead of gasoline engines. How familiar are you with electric cars?
I am very unfamiliar with electric vehicles.
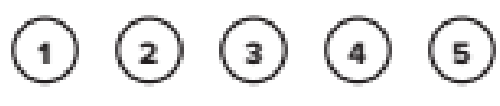
I am very
familiar with electric vehicles.

8a) How interested would you be in owning an electric car?
I am not
interested in owning an
electric car at all
(1)
(2) (3)
(4) (5)
I am very
interested in owning an electric car

8b) If you selected 1-3 for the previous question, what are your reasons for your response?

9) Autonomous vehicles use computers to drive themselves in normal traffic without a driver. How familiar are you with autonomous vehicles?
I am very unfamiliar with autonomous vehicles
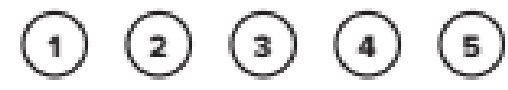
I am very familiar with autonomous vehicles 
10) How comfortable would you be riding in an autonomous (self-driving) vehicle?
I would be very uncomfortable riding in an autonomous vehicle

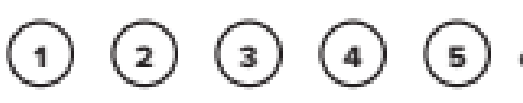
I would be very comfortable riding in an autonomous vehicle

10b) If you selected 1-3 for the previous question, what are your major concerns about autonomous (self-driving) vehicles?

11) Do you experience some kind of mobility related impairment or disability?

$\square$ Yes I $\square$ No

\section{INTERNET AND CELL-PHONE QUESTIONS}

12) How frequently do you use email and/or the internet?

$\square^{1}$ I use the internet multiple times per day

$\square^{2}$ I use the internet daily

$\square^{3}$ I use the internet several times per week

$\square^{4}$ I use the internet about once per week

$\square^{5}$ I use the internet les than once a week or rarely at all

13) At your home, do you have access to the internet?

$\square$ Yes I $\square$ No

14) If you work, at your workplace, do you have access to the Internet?

$\square$ Yes I $\square$ No I $\square$ I do not work or I do not work outside my home

15) If you have a cell phone, how frequently do you use public wifi in order to reduce your use of data on your cell phone plan?

$\square^{1}$ I connect to public wifi whenever it is available to save data

$\square^{2}$ I occasionally connect to public wifi to save data

$\square^{3}$ I rarely or never connect to public wifi to save data.

$\square^{4} \mathrm{~N} / \mathrm{A}$ - I do not have a cellphone

16) Some cell phones are called 'smartphones' because of certain features they have. Is your cell a smartphone or not, or are you not sure?

$\square^{1}$ Yes, it is a smartphone

$\square^{2}$ No, it is not a smartphone

$\square^{3}$ I don't know // I'm not sure

17) Have you ever had to cancel or shut off your cell phone service for a period of time because the cost of maintaining service was too expensive?

$\square$ Yes I $\square$ No I $\square$ N/A-I do not have a cell phone 
18) How comfortable would you be linking your bank account or credit card to an application that allowed you to purchase Trimet passes, reserve a carshare, reserve a Biketown bikeshare, or pay for other transportation services?
I would be very un- comfortable linking my financial information.

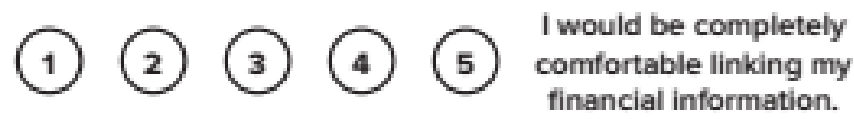

18b) If you selected 1-3 for the previous question, what are your major concerns about linking your financial information?

If you have a smart phone, how often do you use your phone to... (applies to questions 19 to 22 )

19) Get public transit information?

$\square^{1} \mathbf{5}$ or more days a week

$\square^{2} 3-4$ days a week

$\square^{3} 1-2$ days a week

$\square^{4} 1-3$ days a month

$\square^{5}$ Less than once a month/ never

20) Get navigation while you are driving, cycling, or walking?

$\square^{1} 5$ or more days a week

$\square^{2} 3-4$ days a week

$\square^{3} 1-2$ days a week

$\square^{4} 1-3$ days a month

$\square^{5}$ Less than once a month/ never

21) Reserve a taxi, Uber, Lyft, Car2Go, or another ridesharing or carsharing service?

$\square^{1} 5$ or more days a week

$\square^{2} 3-4$ days a week

$\square^{3} 1-2$ days a week

$\square^{4} 1-3$ days a month

$\square^{5}$ Less than once a month/ never

22) Reserve or find a share bike (i.e. Biketown)?

$\square^{1} \mathbf{5}$ or more days a week

$\square^{2}$ 3-4 days a week

$\square^{3} 1-2$ days a week

$\square^{4} 1-3$ days a month

$\square^{5}$ Less than once a month/ never 


\section{POLICY QUESTIONS}

23) Below is a list of possible transportation policies that the City of Portland could pursue in support of it's Smart Cities goals. Choose three policies from the list of ten below that you would most like to see implemented:

(Select only 3 policies)

$\square^{1}$ Smartphone applications for transportation services translated to languages other than English

$\square^{2}$ Public wifi and charging stations for smartphone/mobile technology

$\square^{3}$ More electric vehicle charging stations

$\square^{4}$ Rebates or financing to help purchase clean electric vehicles

$\square^{5}$ Expansion of the Biketown bike-share program outside of central city neighborhoods

$\square^{6}$ Expansion of car sharing services that allow short-term vehicle rentals to more neighborhoods

$\square^{7}$ Self-driving neighborhood shuttles to bring people to transit stops

$\square^{8}$ Real time communication between buses and riders about crowding, arrival time, etc

$\square^{9}$ More public outreach and education around smartphone applications for transportation services

$\square^{10}$ More public outreach and education about different mobility options like car sharing, Biketown bike share, etc 
24) Which of the following types of neighborhood institutions or places would you most trust to gain access to information about transportation services?

(Select all that apply)

$\square^{1}$ Church or Place of Worship

$\square^{2}$ Community Center

$\square^{3}$ Neighborhood Public School

$\square^{4}$ Public Libraries

$\square^{5}$ TriMet Transit Station

$\square^{6}$ Grocery Store or Market (i.e. Fred Meyer, Plaid Pantry)

$\square^{7}$ Non-profit Organization (i.e. IRCO, Oregon Food Bank, Hacienda CDC, etc.)

$\square^{8}$ Other:

25) If trainings were provided about how to use smartphone apps or other web-based technology to gain access to public transportation, carshare, bikeshare, or other mobility services, would you prefer the education be provided...

(Select all that apply)

$\square^{1}$ As an in person training with a TriMet or City of Portland employee

$\square^{2}$ Through a web-based video (i.e. a Youtube training)

$\square^{3}$ Through a printed booklet or informational flyer

$\square^{4}$ Other: 


\section{INFORMATION ABOUT YOU AND YOUR HOUSEHOLD}

26) What year were you born?

27) Are you:

$\square^{1}$ Female

$\square^{2}$ Male

$\square^{3}$ Non-binary/ third gender

$\square^{4}$ Prefer to self-describe

$\square^{5}$ Prefer not to say

28) How many children or dependents live in your home?

$\square^{1}$ None

$\square^{2} 1-2$

$\square^{3} 3-4$

$\square^{4} 5$ or more

29) What is the highest level of education you have completed?

$\square^{1}$ Less than high school degree

$\square^{2}$ High school graduate/GED

$\square^{3}$ Some college/technical school

$\square^{4}$ College degree

$\square^{5}$ College \& graduate work

30) Are you:

$\square^{1}$ Employed full time

$\square^{2}$ Employed part time

$\square^{3}$ Student

$\square^{4}$ Homemaker

$\square^{5}$ Unemployed

$\square^{6}$ Retired

31) What was your approximate annual household income range last year?

$\square^{1}$ Less than $\$ 14,999$

$\square^{2} \$ 15,000$ to $\$ 24,999$

$\square^{3} \$ 25,000$ to $\$ 34,999$

$\square^{4} \$ 35,000$ to $\$ 49,999$

$\square^{5} \$ 50,000$ to $\$ 74,999$

$\square^{6} \$ 75,000$ to $\$ 99,999$

口 $\$ 100,000$ to $\$ 149,999$

$\square^{8} \$ 150,000$ or more 
32) Are you Hispanic or Latino (of any race)?

$\square$ Yes I $\square$ No

33) What is your race? (Please Check Only One)

$\square^{1}$ Black or African American

$\square^{2}$ White/Caucasian

$\square^{3}$ American Indian and Alaska Native

$\square^{4}$ Asian

$\square^{5}$ Native Hawaiian and Other Pacific Islander

$\square^{6}$ Some other race

$\square^{7}$ Two or more races

34) What is your zip code?

35) What kind of housing structure do you live in?

$\square^{1}$ Apartment/Condo in a building with many units and a single entrance

$\square^{2}$ Townhome/attached home with your own entrance

$\square^{3}$ Single family detached home

$\square^{4}$ Other:

36) At your home, would you be able to easily charge an electric vehicle (car or bicycle)?

$\square^{1}$ Yes - I have a garage or area where I can put my vehicle near an electric outlet

$\square^{2}$ No -1 have no access to an outlet near the parking area

$\square^{3}$ Perhaps - with some modification, I could get power to charge a vehicle

37) Do you have a checking or savings account?

$\square$ Yes I $\square$ No

38) Do you have a credit card account or prepaid account?

$\square$ Yes I $\square$ No

THANK YOU FOR YOUR PARTICIPATION 


\section{APPENDIX B - DETAILED SURVEY QUESTION RESULTS}

This appendix presents detailed results for each survey question. It presents overall results and then breaks the results down by age category, income category and racial/ethnic category outlined earlier in the report. The dark line below the comparisons indicate a statistically significant difference between the two groups (using a Chi-Square test with $\mathrm{p}<0.1$ ). Otherwise, the groups are not significantly different and are assumed to be roughly equivalent.

\section{BASIC TRANSPORTATION ACCESS}

Table B1. How many cars, trucks, vans, or motorcycles are available in your household for you to use?

How many cars, trucks, vans, or motorcycles are available in your household for you to use?

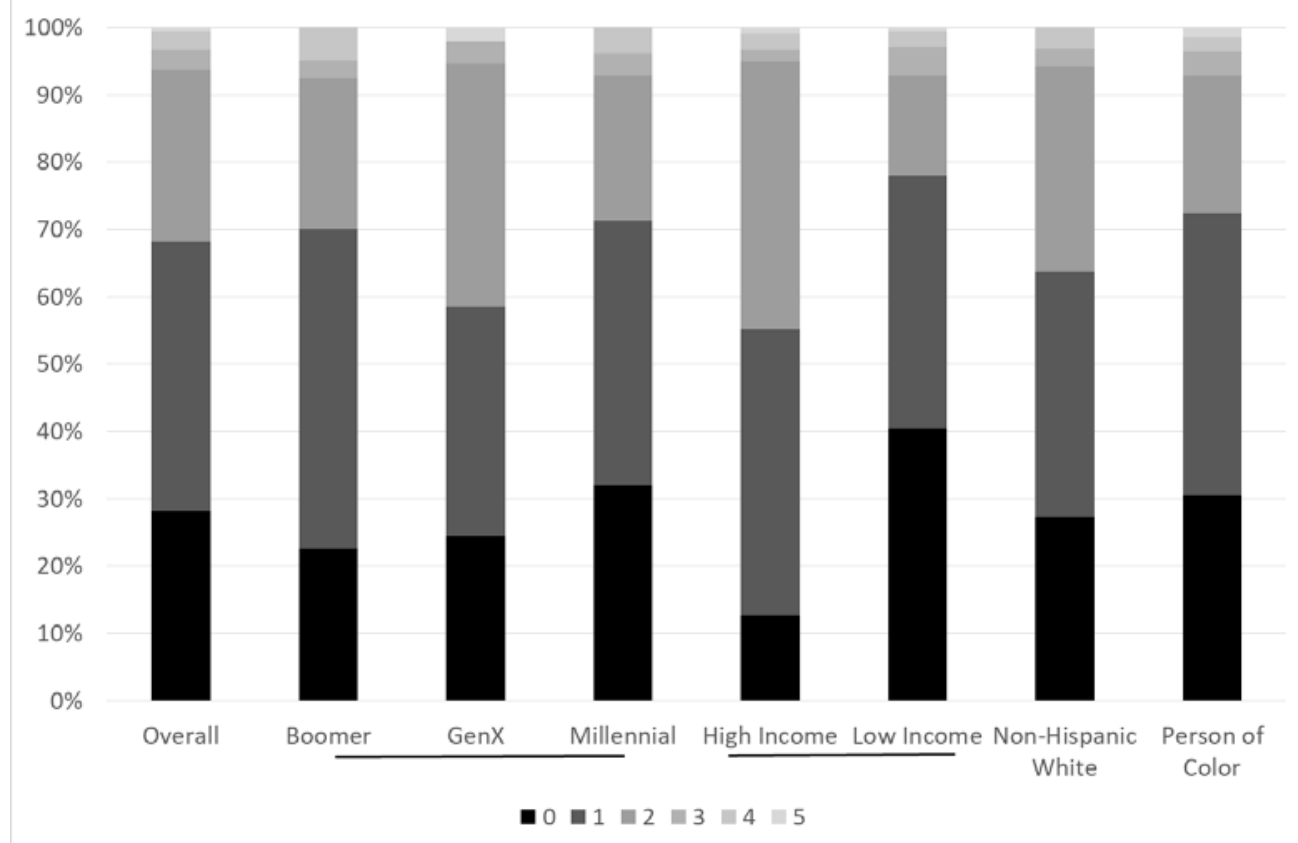


Table B2. Of the cars available to you, do you lease, make payments, or own them? Of the cars available to you, do you lease, make payments, or own them?

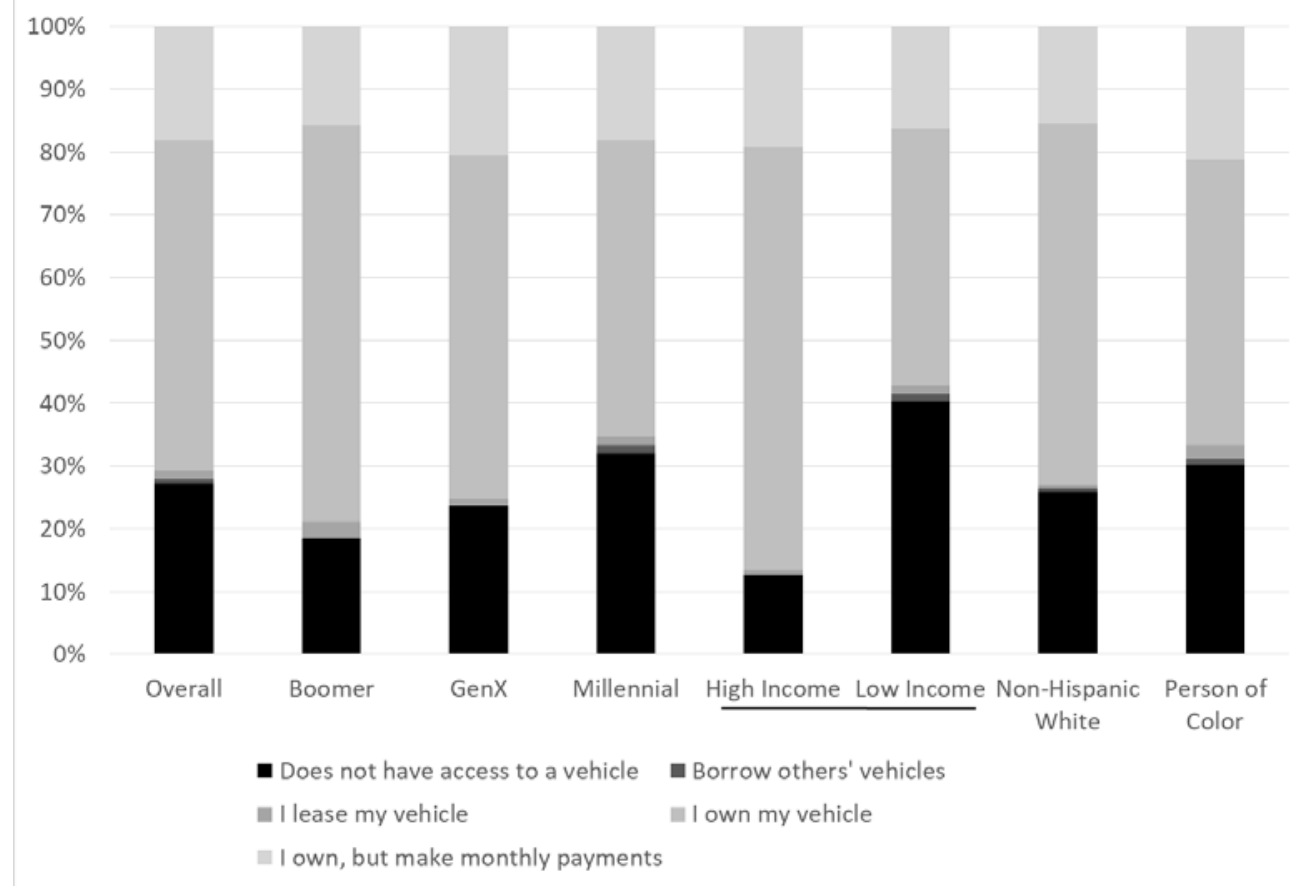

Table B3. Do you have a driver's license?

Do you have a driver's license?

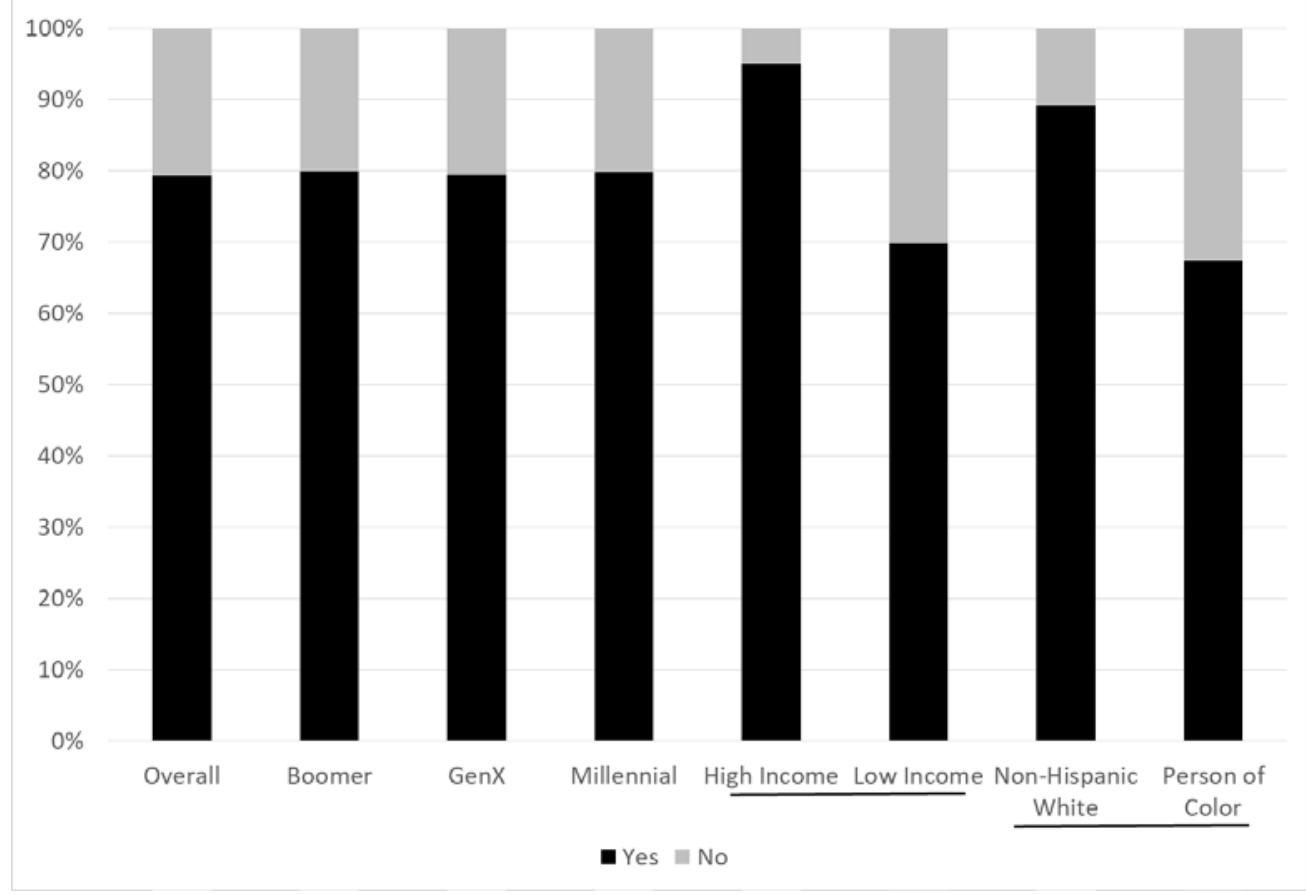


Table B4. Do you experience some kind of mobility-related impairment or disability? Do you experience some kind of mobility related impairment or disability?

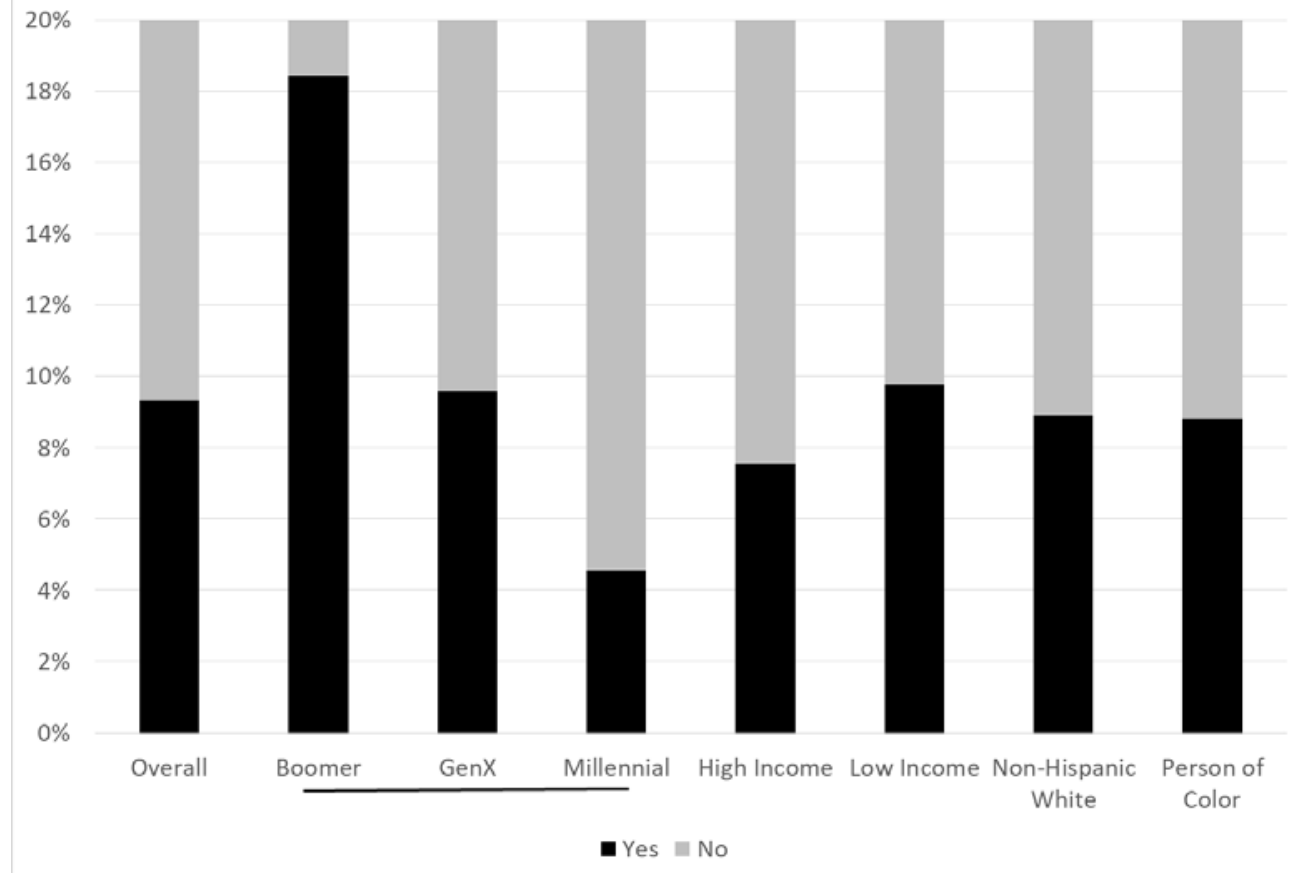

Table B5. Does your employer / school provide you a transit pass?

Does your employer / school provide you a transit pass?

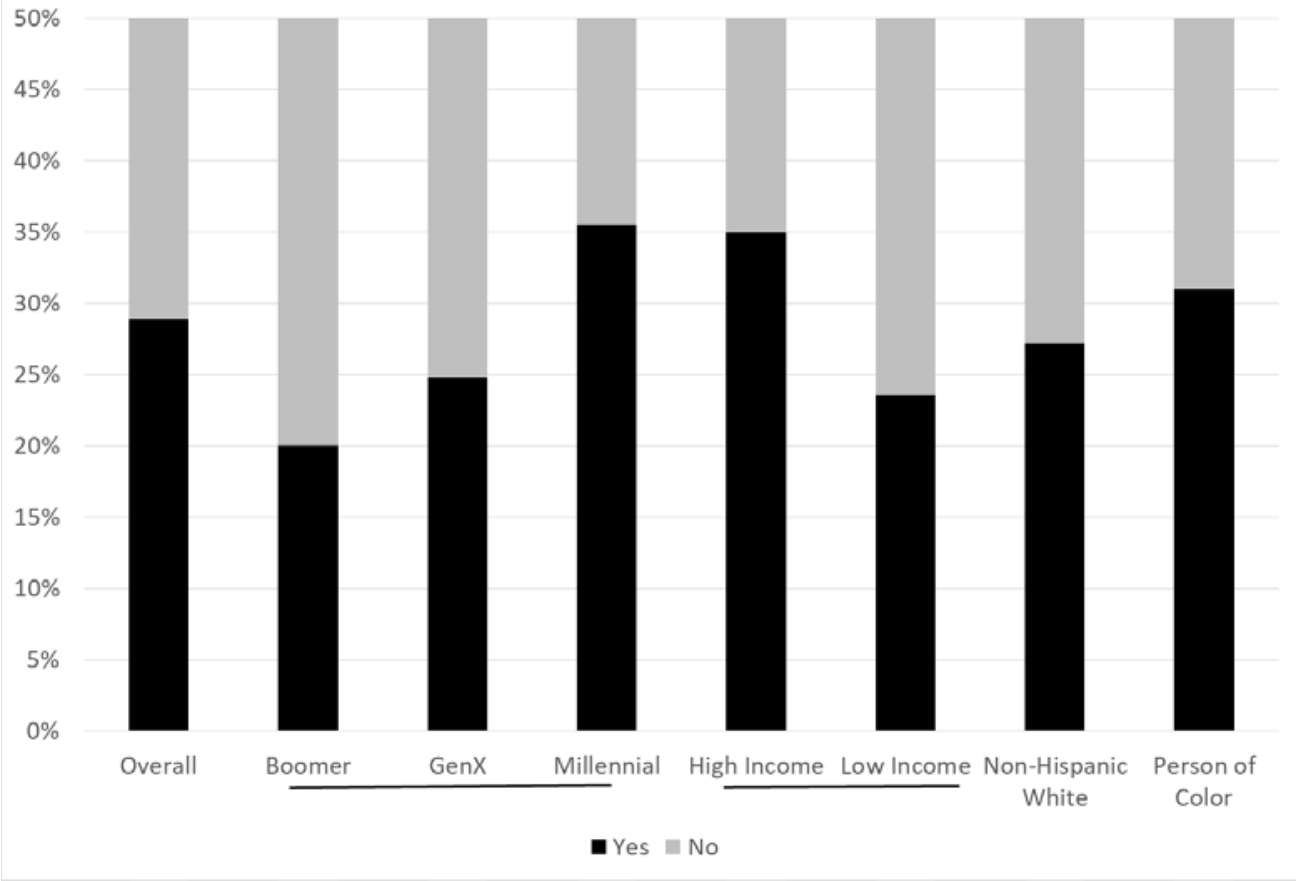


Table B6. Does your employer / school provide free parking?

Does your employer / school provide free parking?

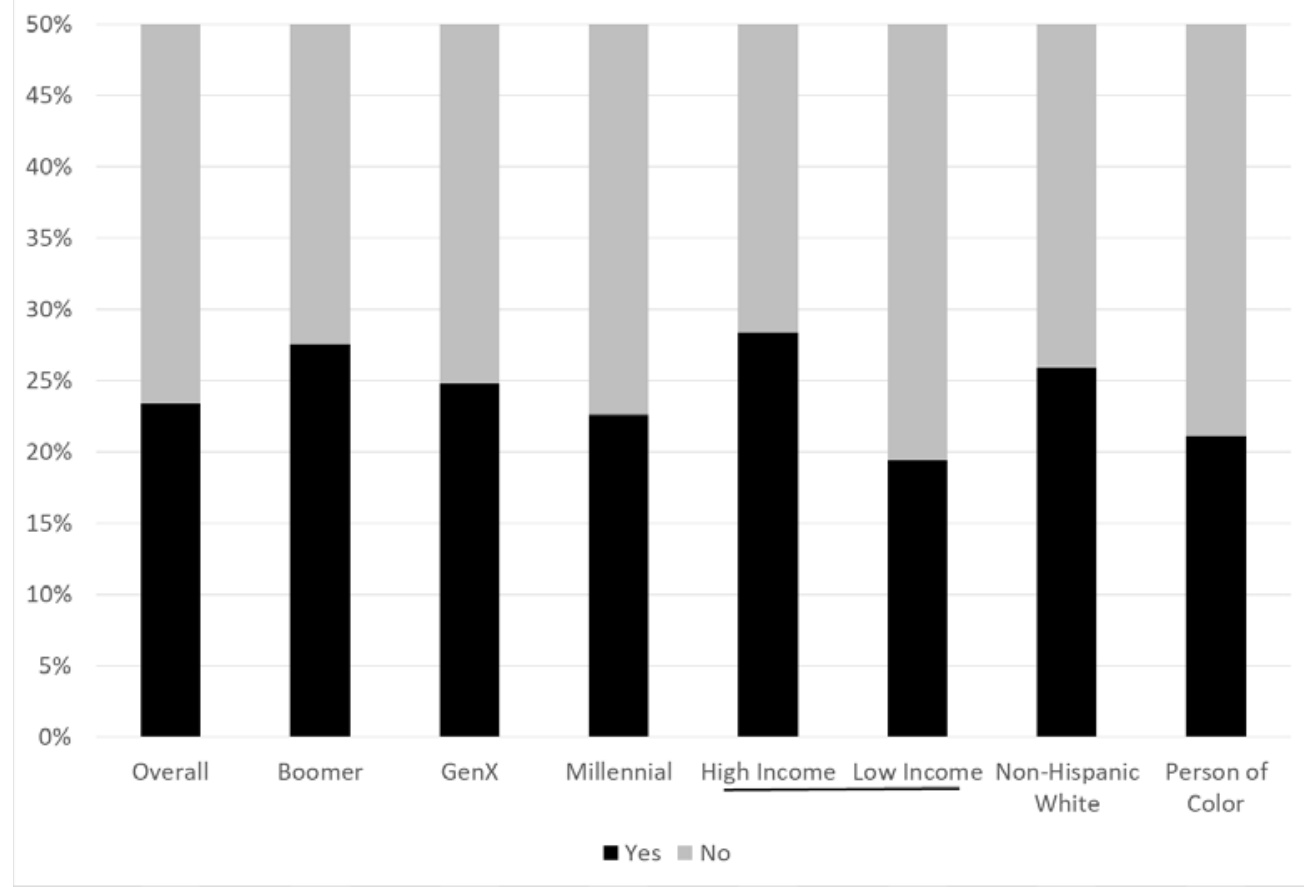

Table B7. Does your employer / school provide secure onsite bicycle parking? Does your employer / school provide secure onsite bicycle parking?

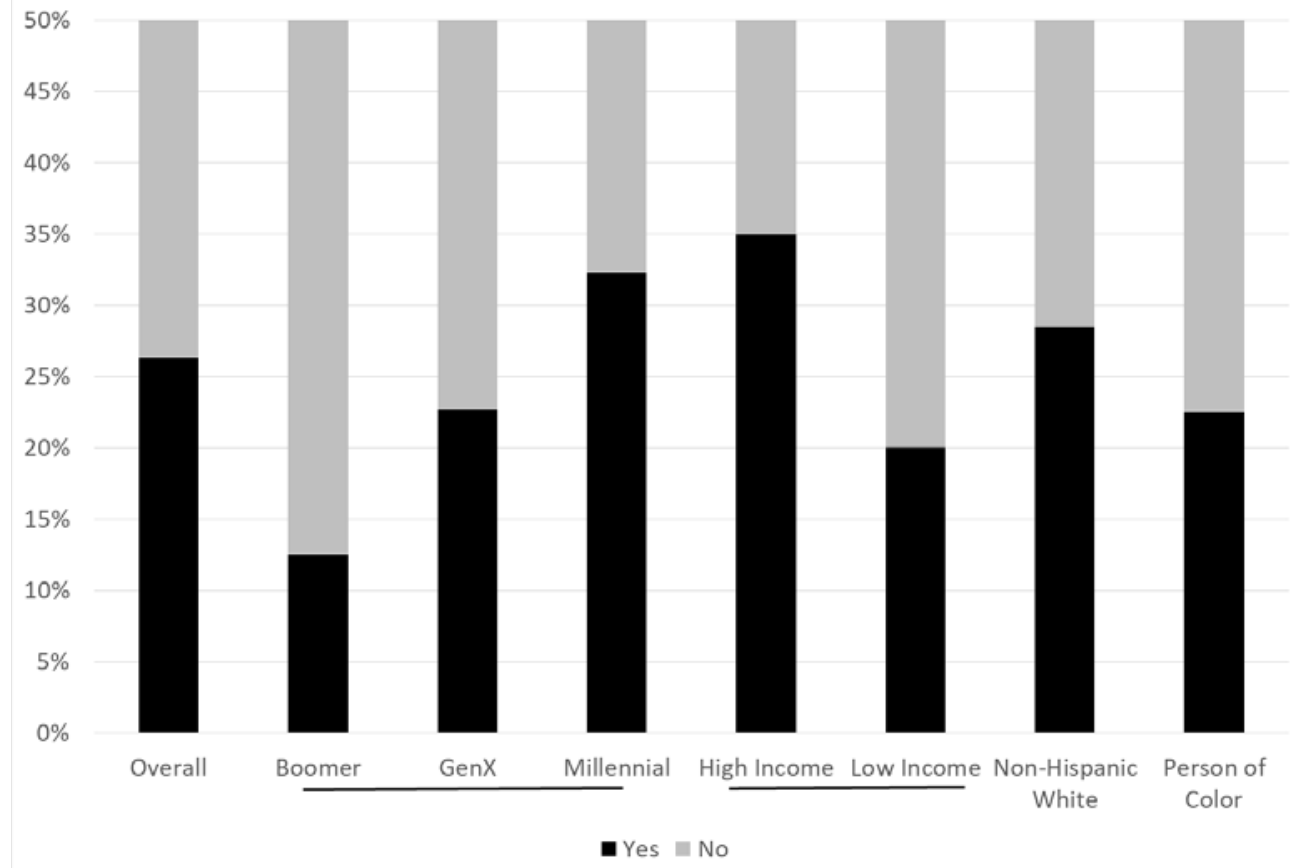


Table B8. Does your employer / school provide you a company vehicle?

Does your employer / school provide you a company vehicle?

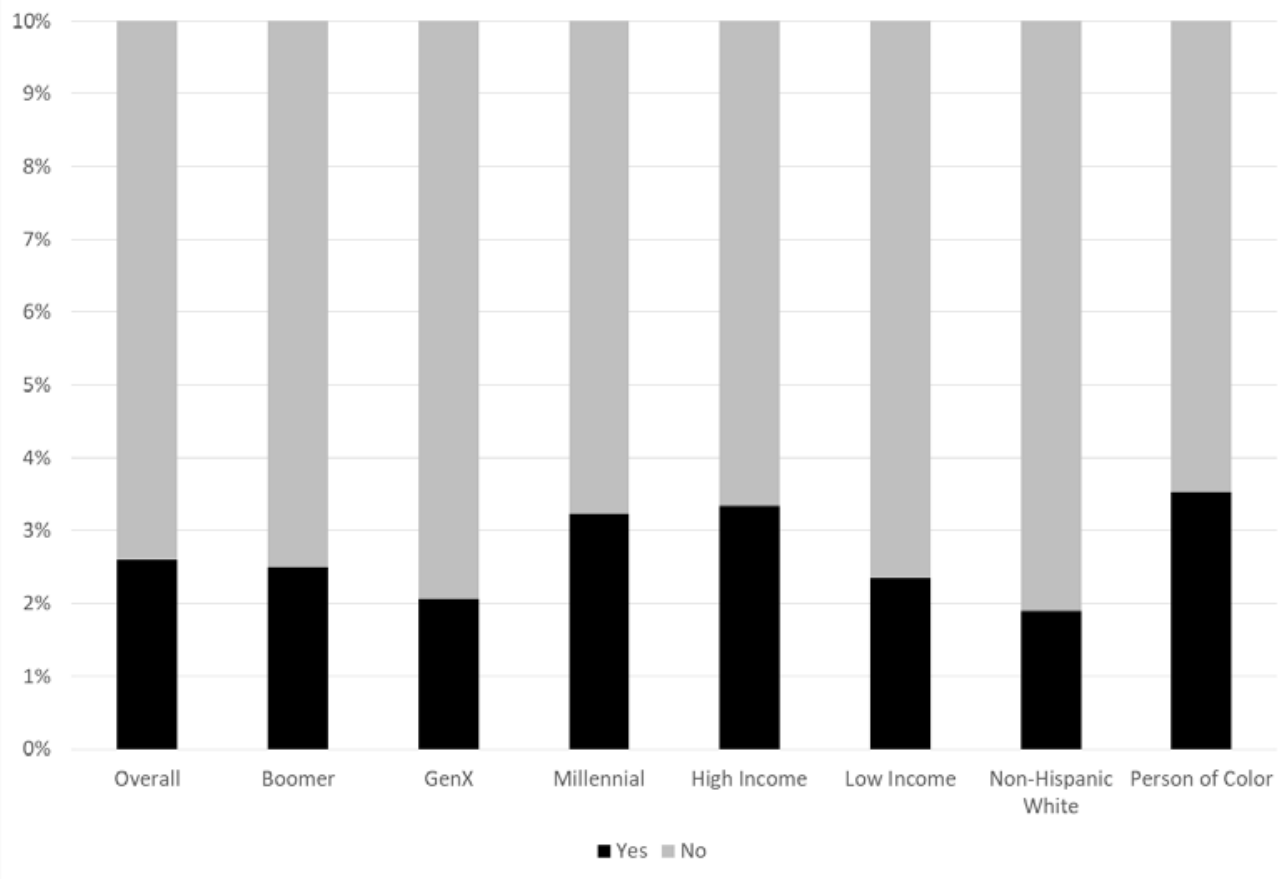

Table B9. Does your employer / school provide you access to an electric vehicle charger? Does your employer / school provide you access to an electric vehicle charger?

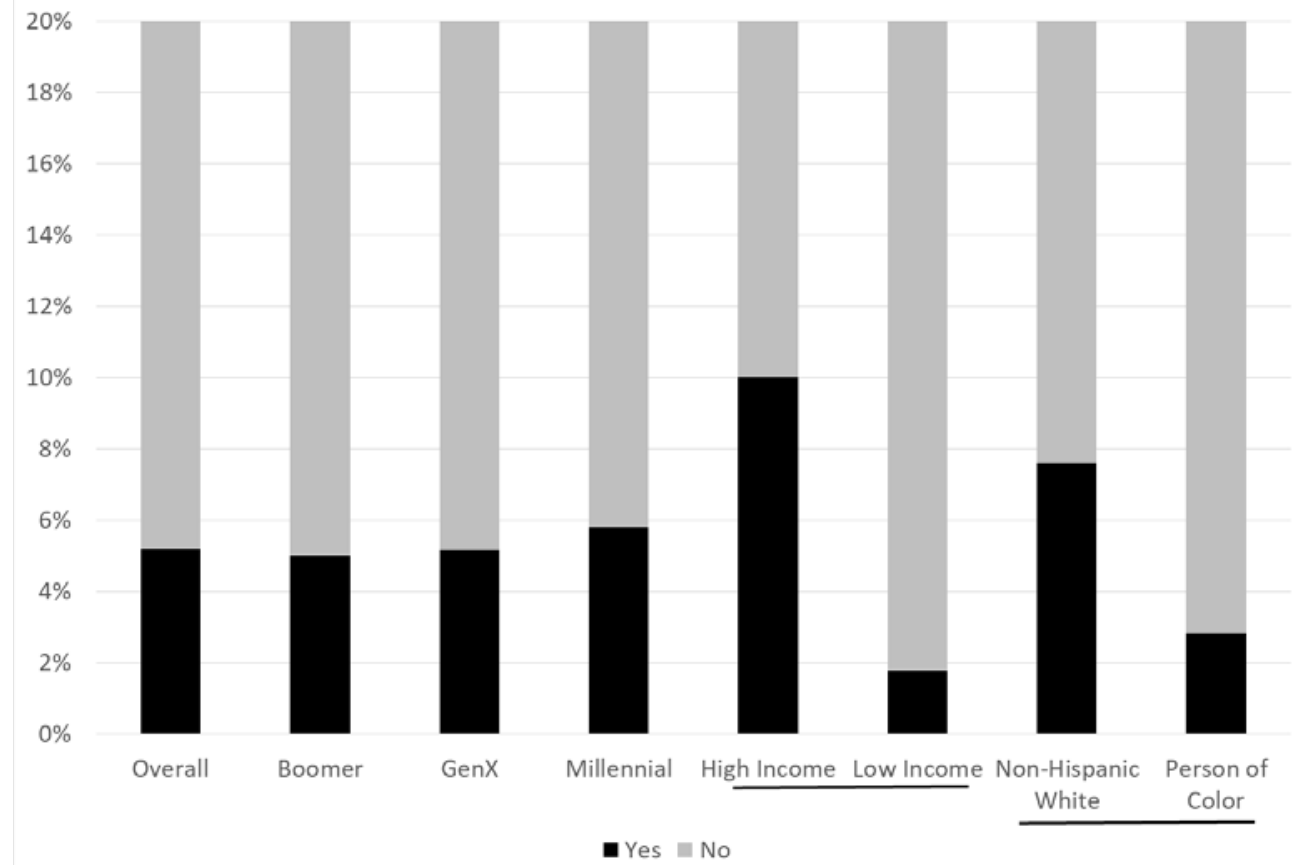


Table B10. Does your employer / school provide you a Biketown subscription? Does your employer / school provide you a Biketown subscription?

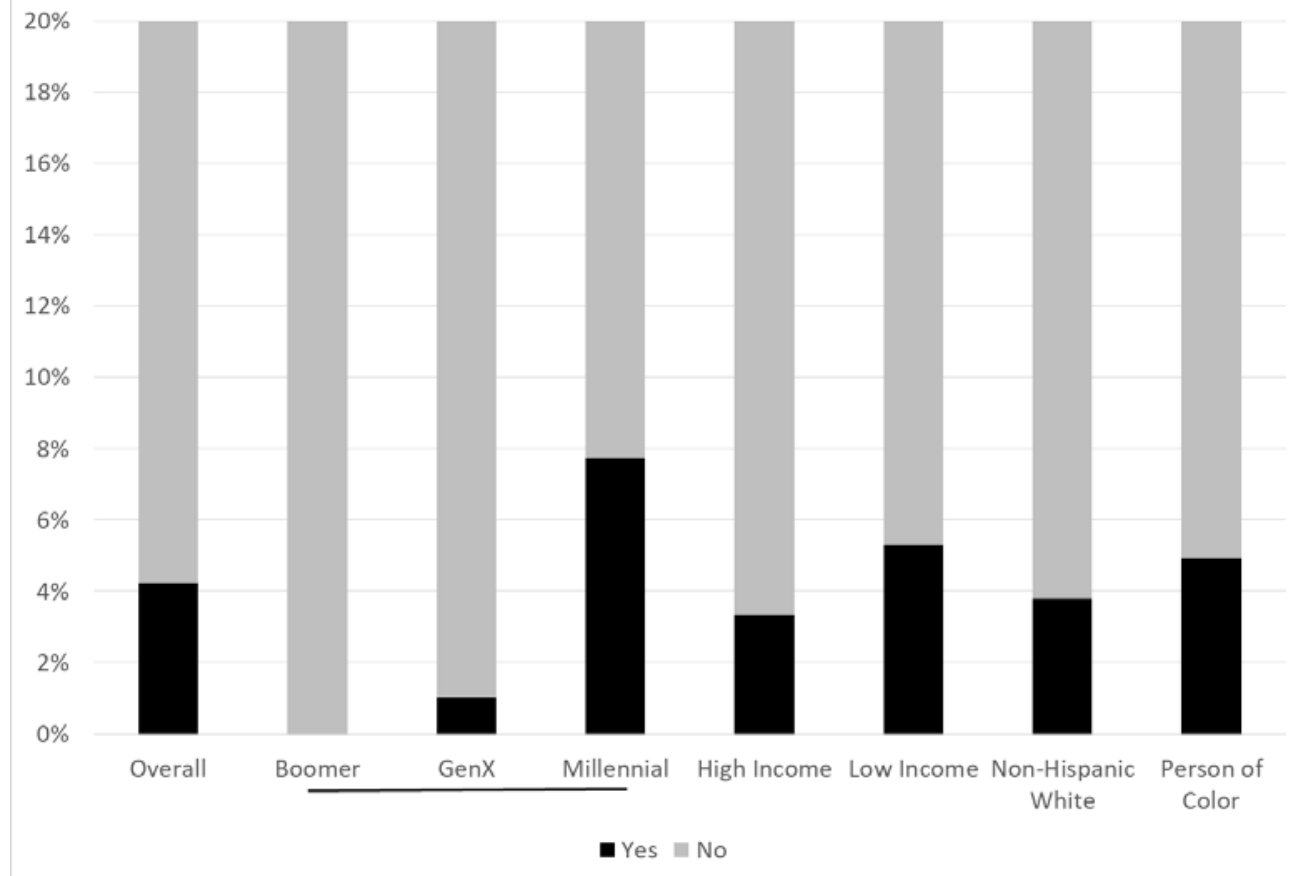

Table B11. The most common mode of travel to work: Drive alone

The most common mode of travel to work: Drive alone

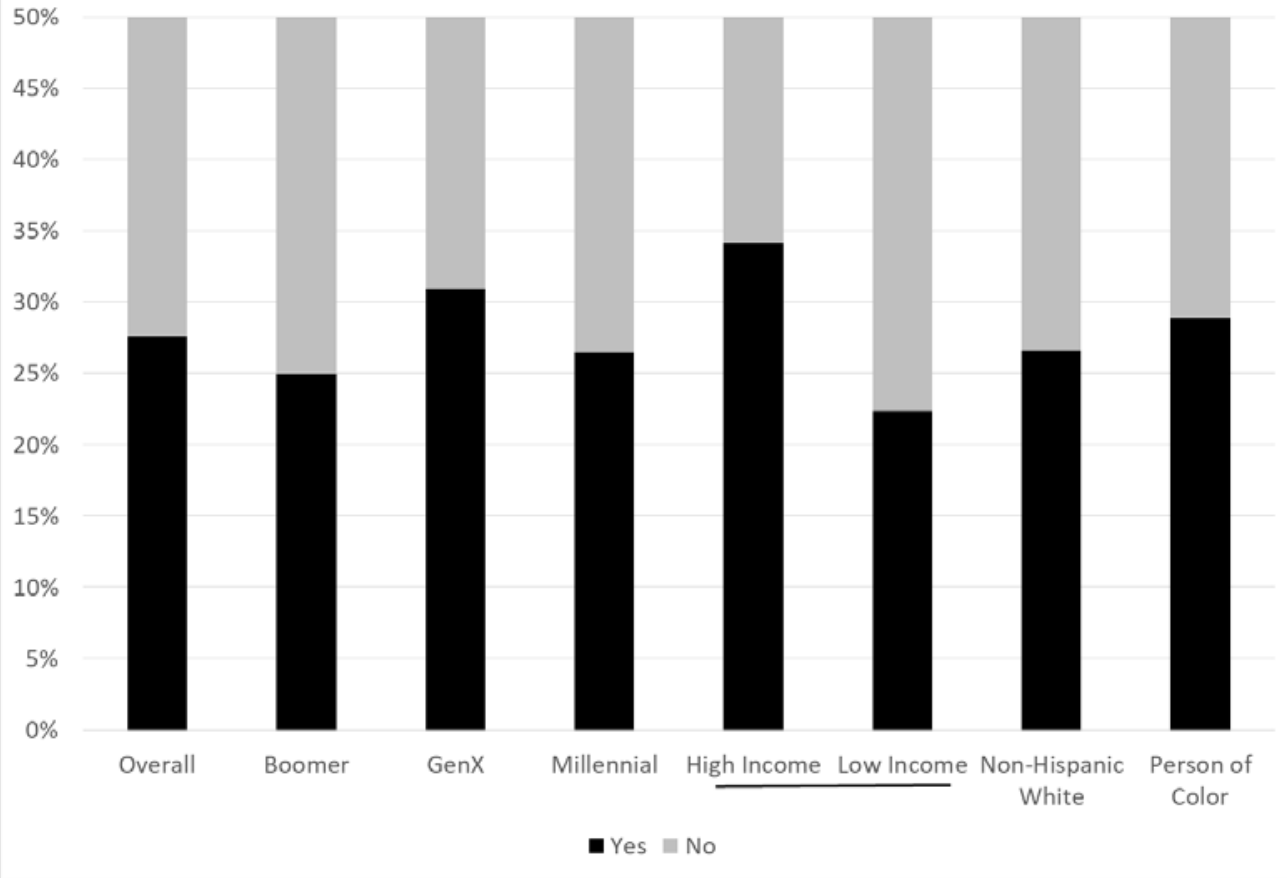


Table B12. The most common mode of travel to work: Carpool

The most common mode of travel to work: Carpool

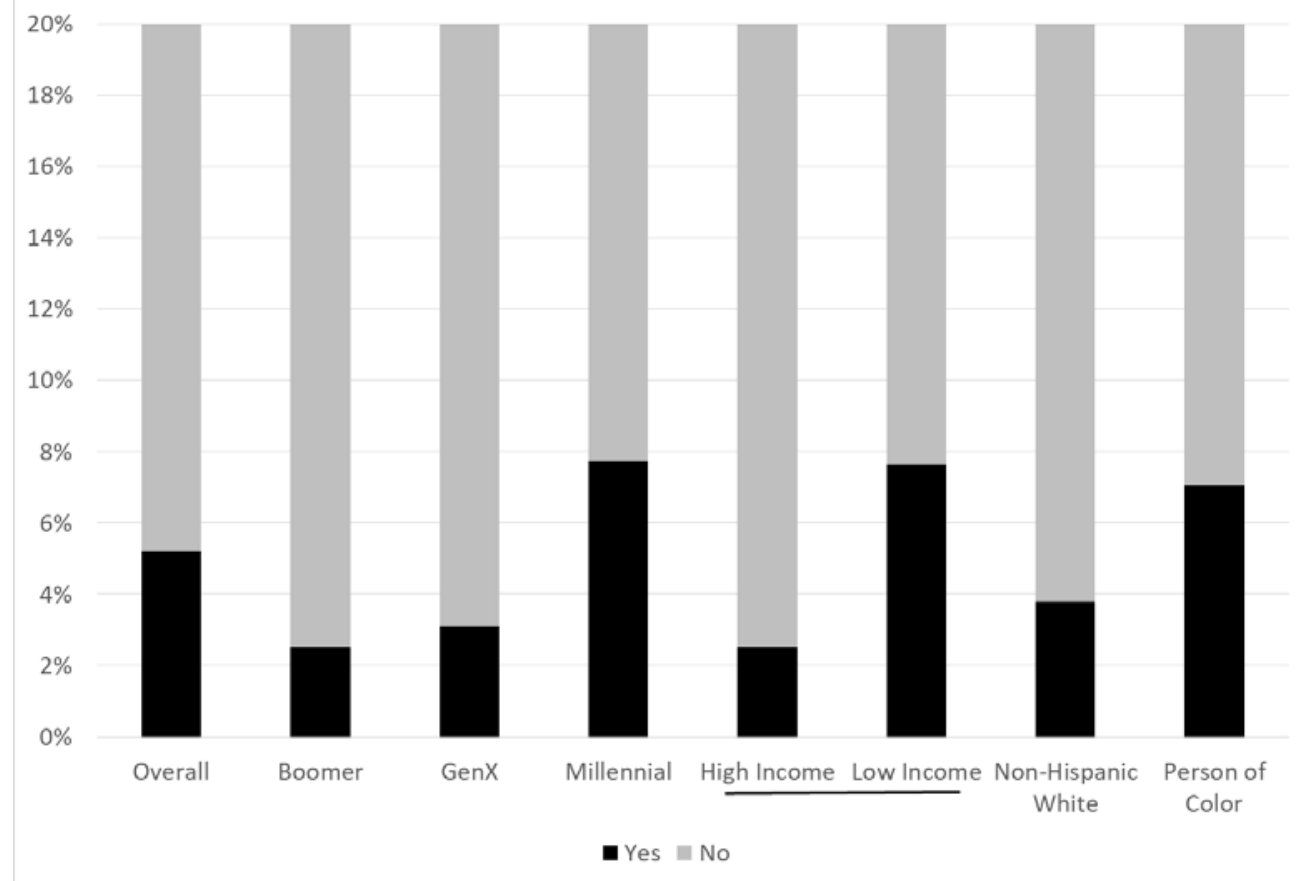

Table B13. The most common mode of travel to work: Public transportation

The most common mode of travel to work: Public transportation

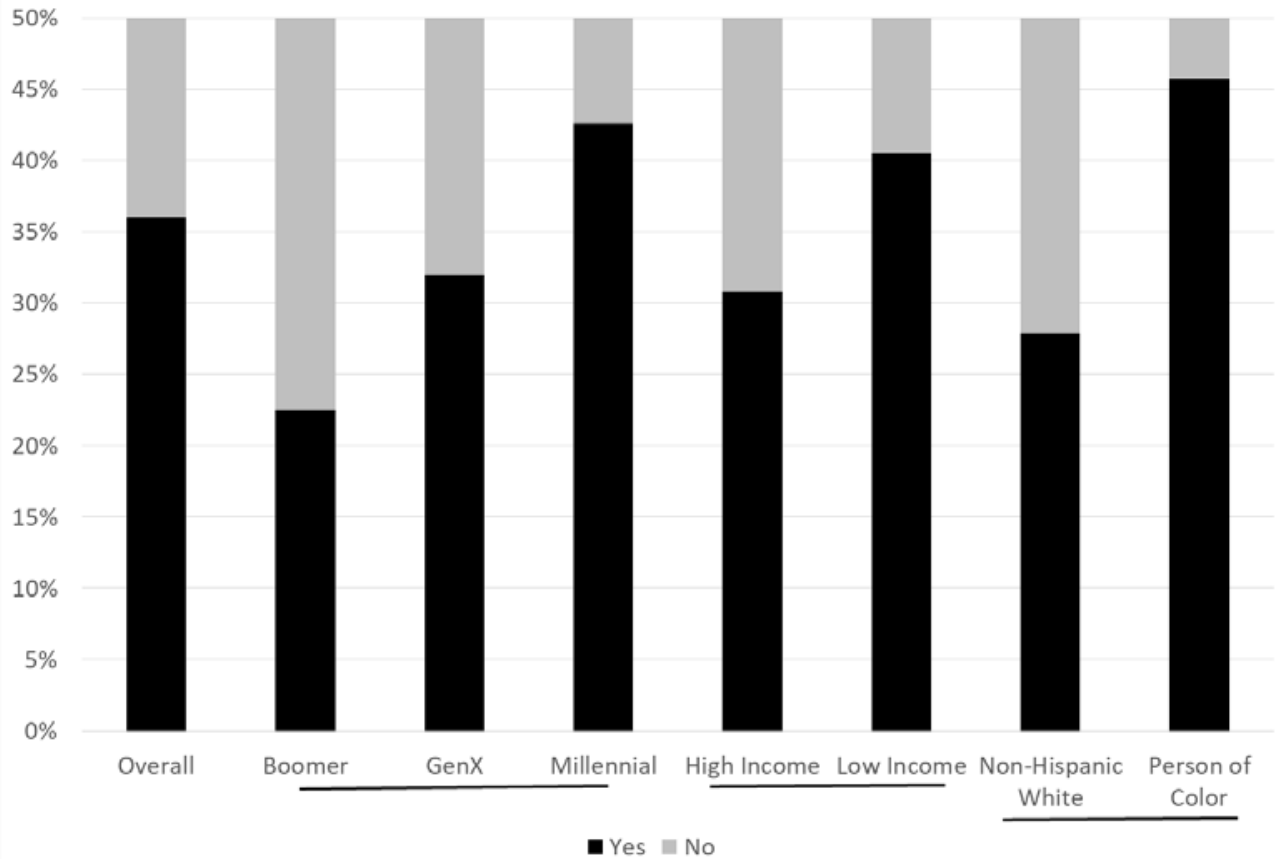


Table B14. The most common mode of travel to work: Walked

The most common mode of travel to work: Walked

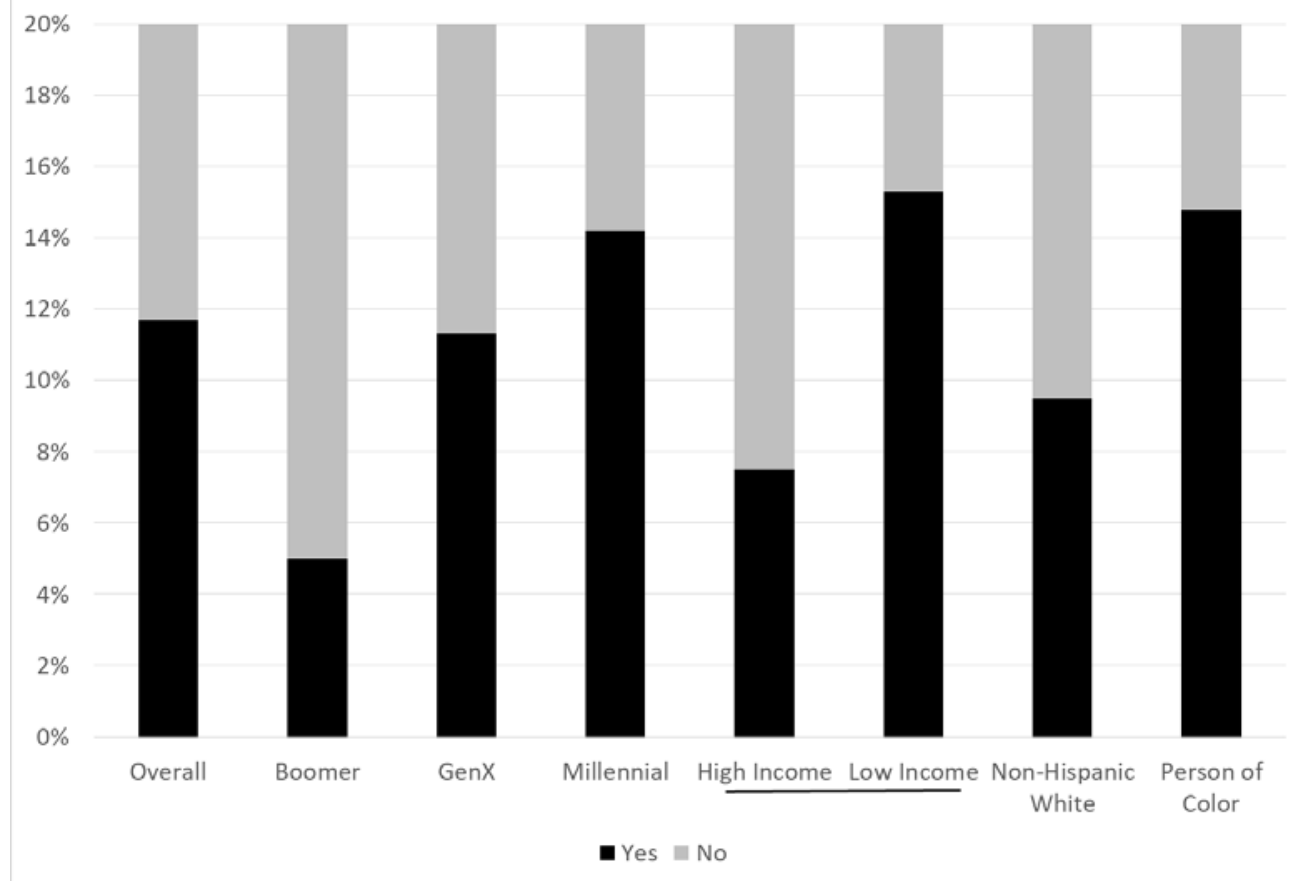

Table B15. The most common mode of travel to work: Bicycle

The most common mode of travel to work: Bicycle

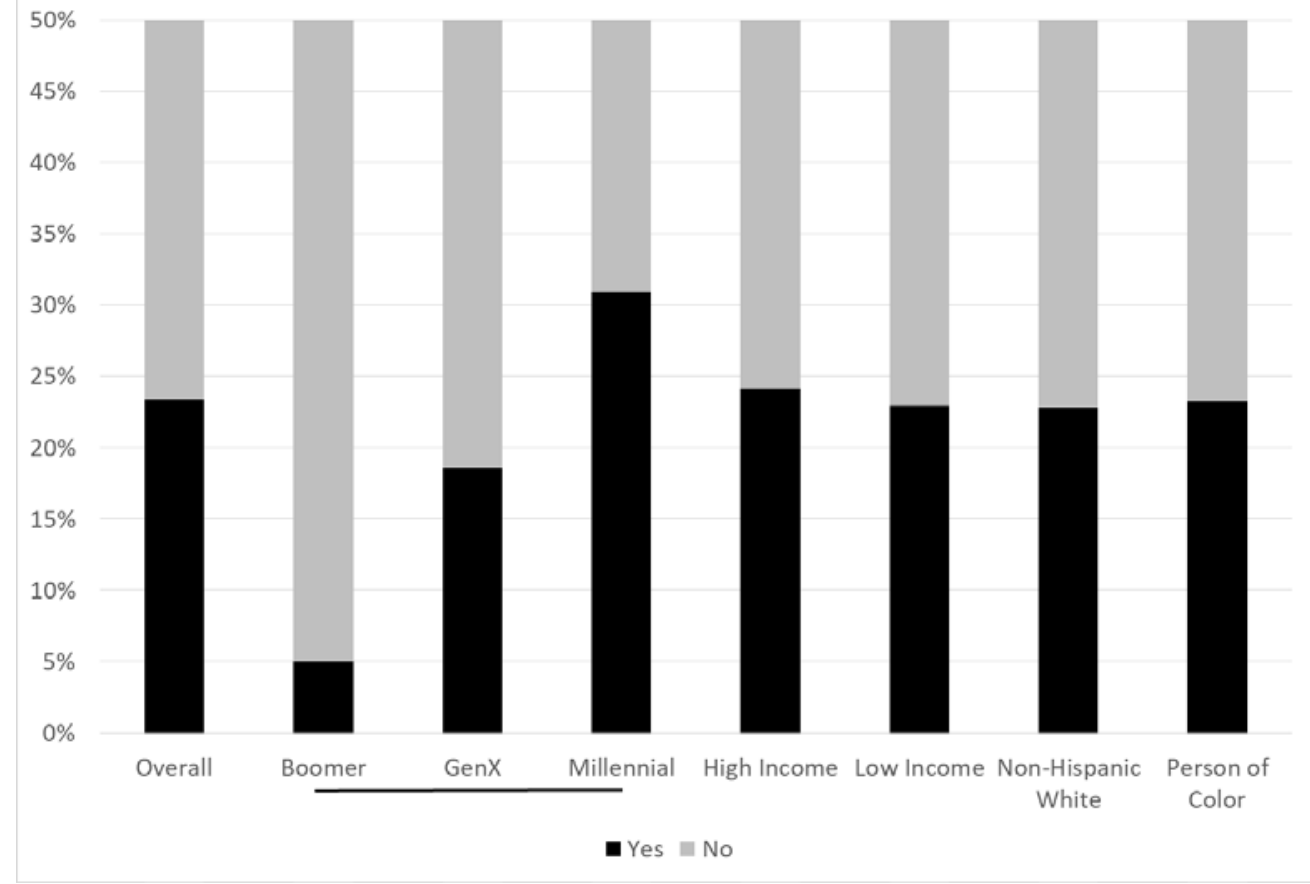


Table B16. The most common mode of travel to work: Ridesourcing (TNCs)

The most common mode of travel to work: Ridesourcing (TNCS)

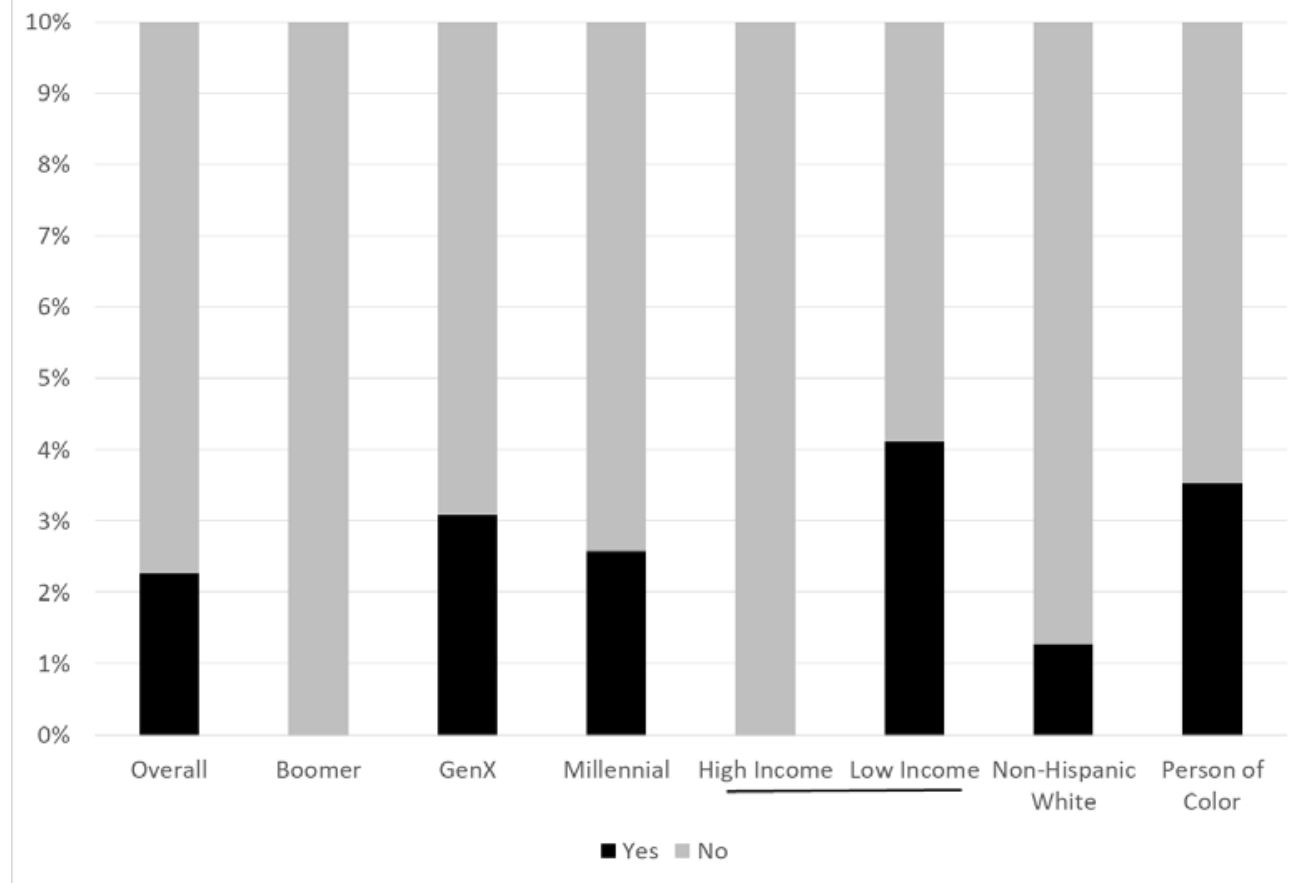

Table B17. The most common mode of travel to work: Work at home

The most common mode of travel to work: Work at home

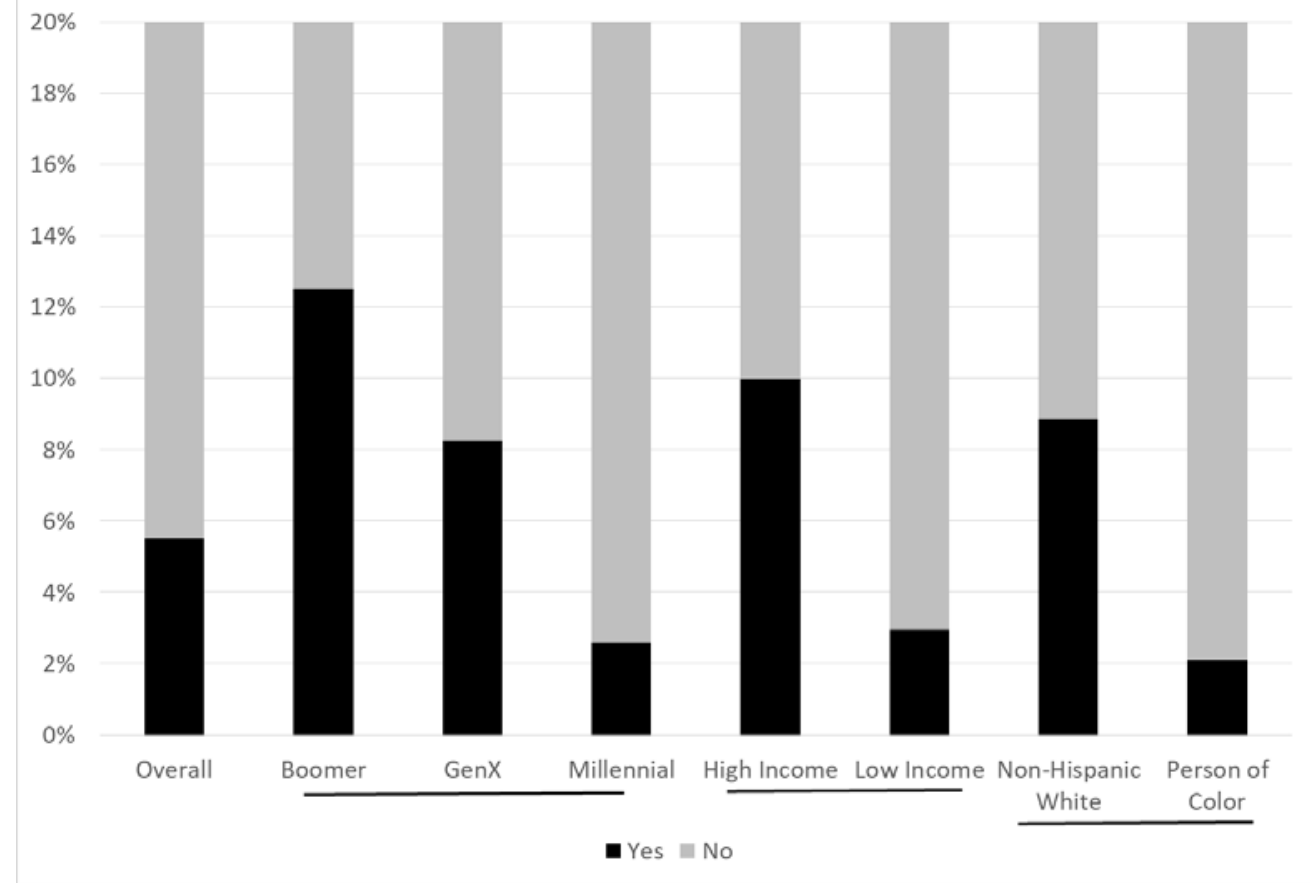


Table B18. How do you typically pay for the TriMet fare: On board How do you typically pay for the TriMet fare: On board

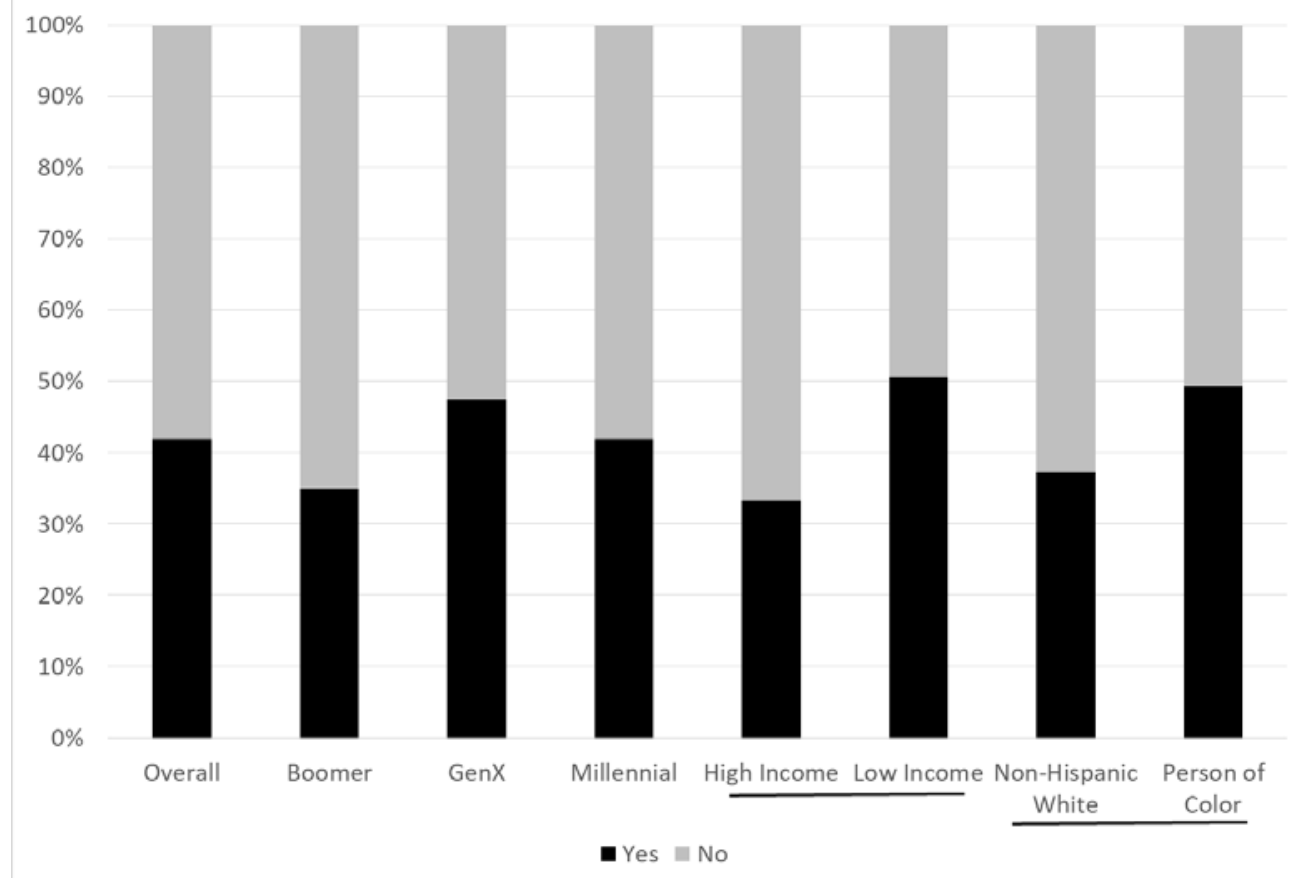

Table B19. How do you typically pay for the TriMet fare: TriMet or retail store How do you typically pay for the TriMet fare: TriMet or retail store

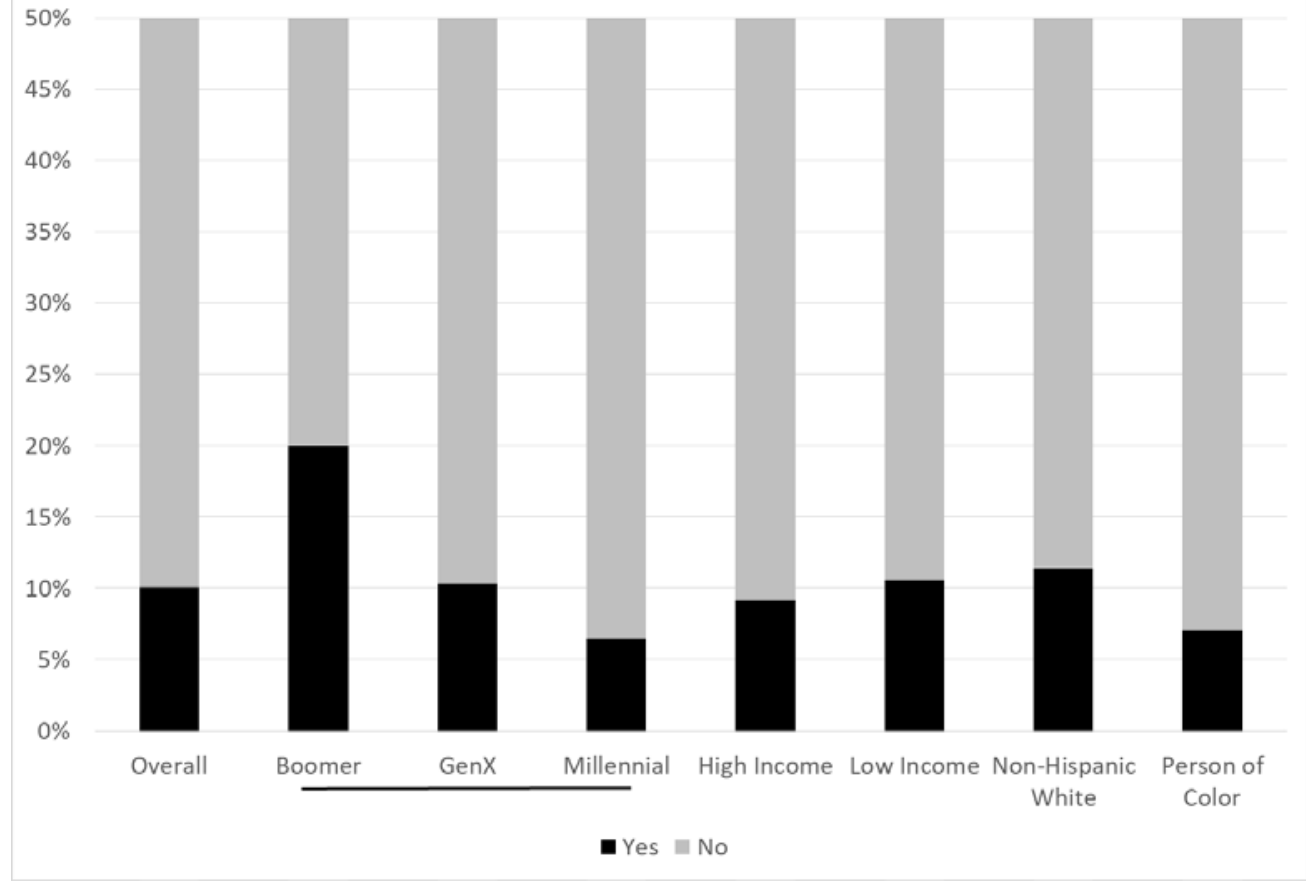


Table B20. How do you typically pay for the TriMet fare: School or Work How do you typically pay for the TriMet fare: School or Work

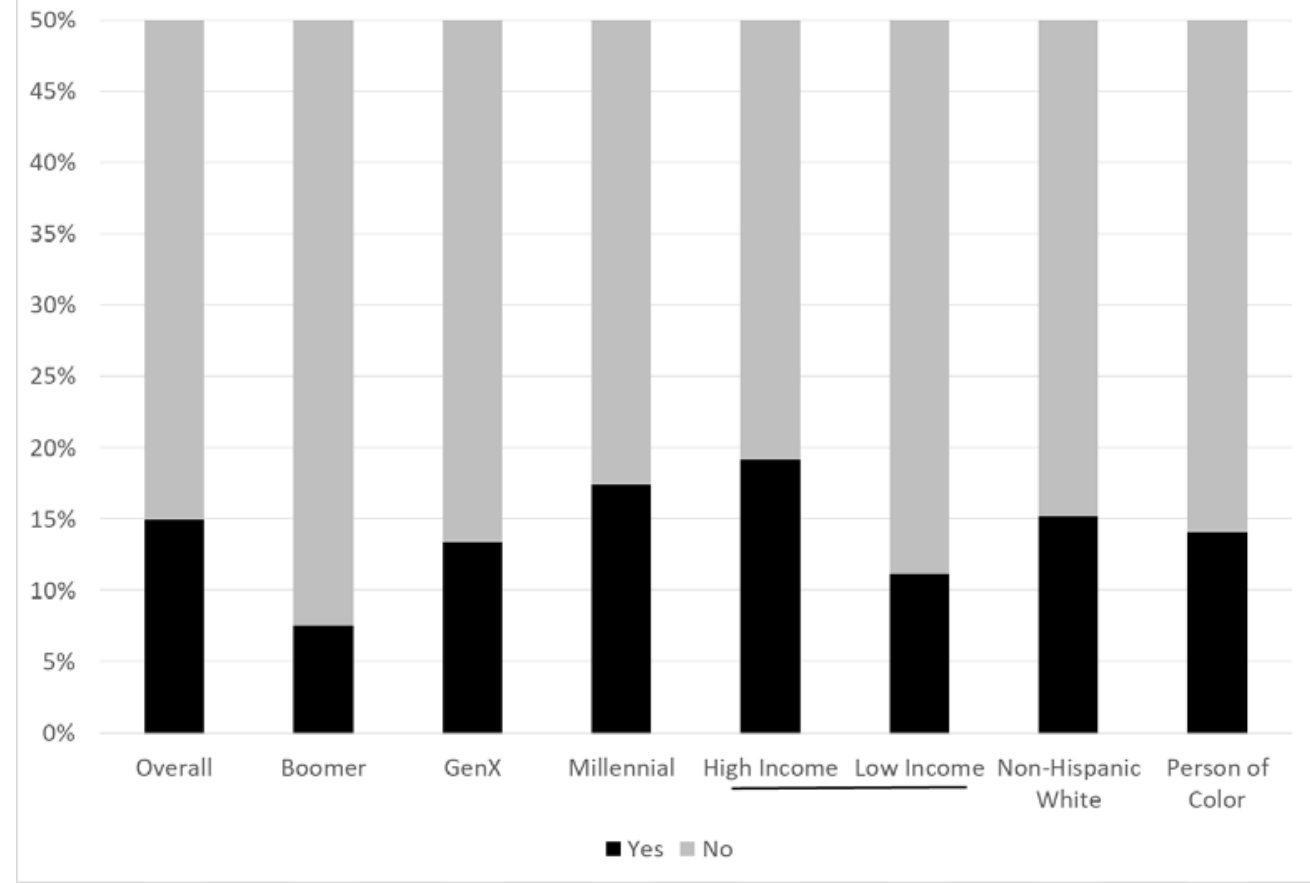

Table B21. How do you typically pay for the TriMet fare: Online or Phone App How do you typically pay for the TriMet fare: Online or Phone App

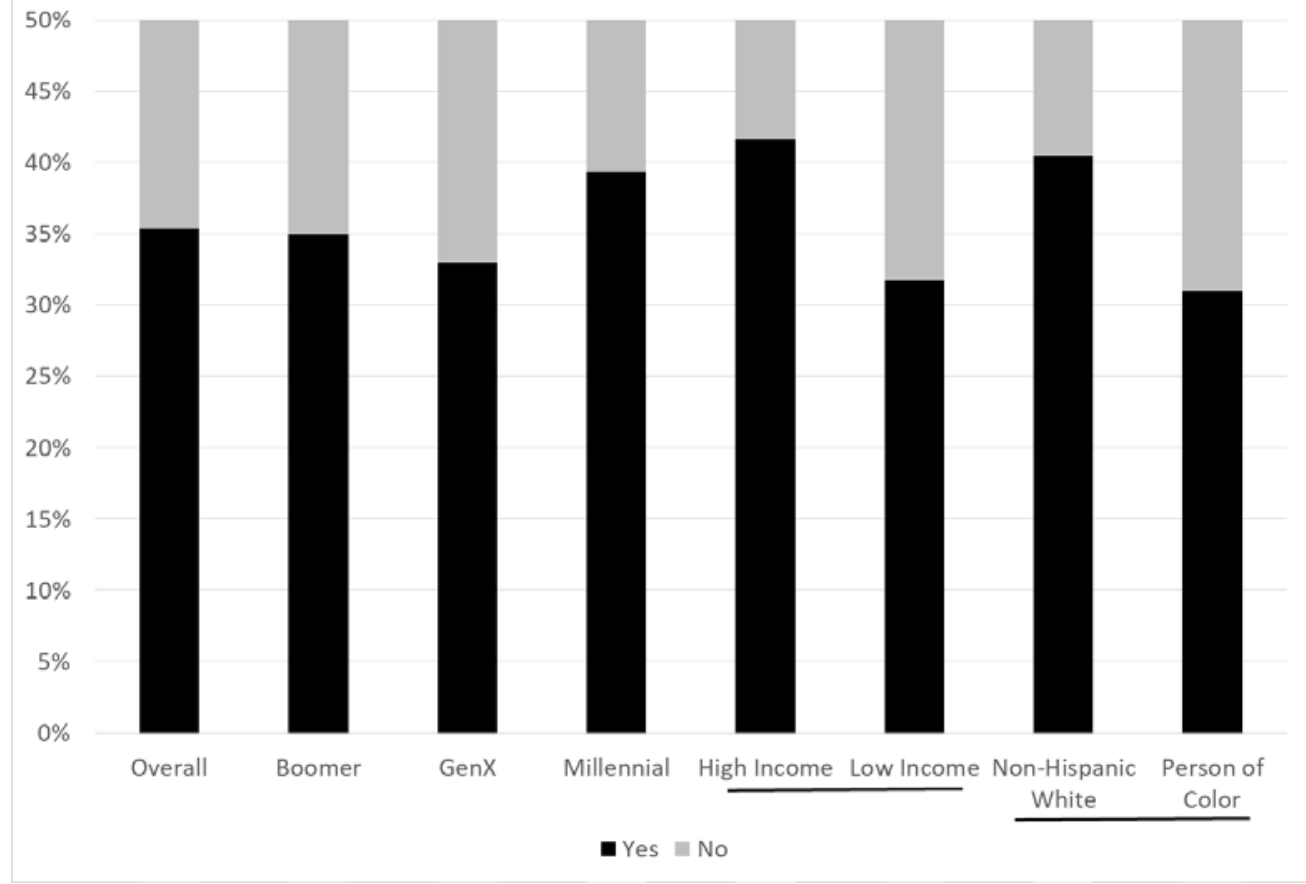


Table B22. How do you typically pay for the TriMet fare: Social service agency How do you typically pay for the TriMet fare: Social service agency

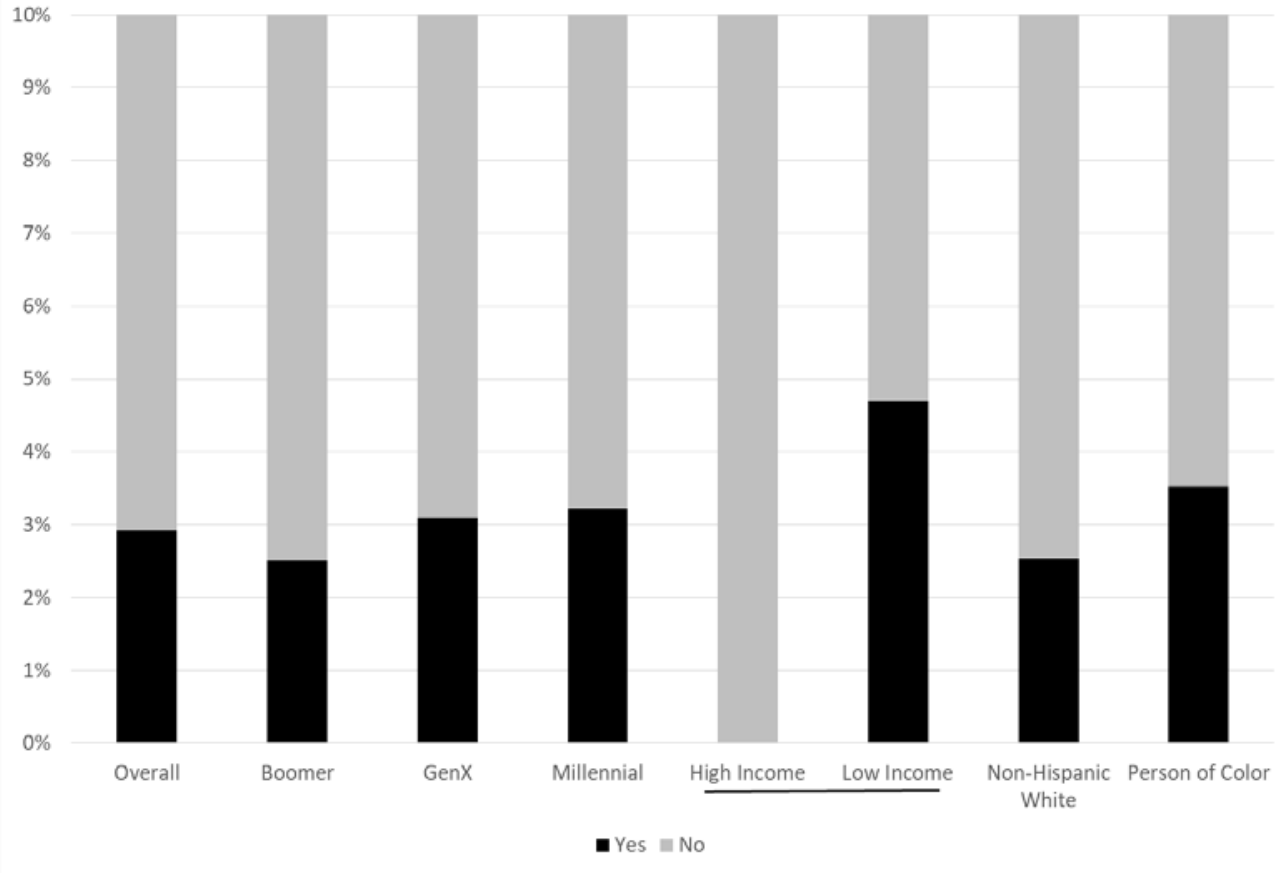


New transportation technologies

Table B23. How familiar are you with electric cars?

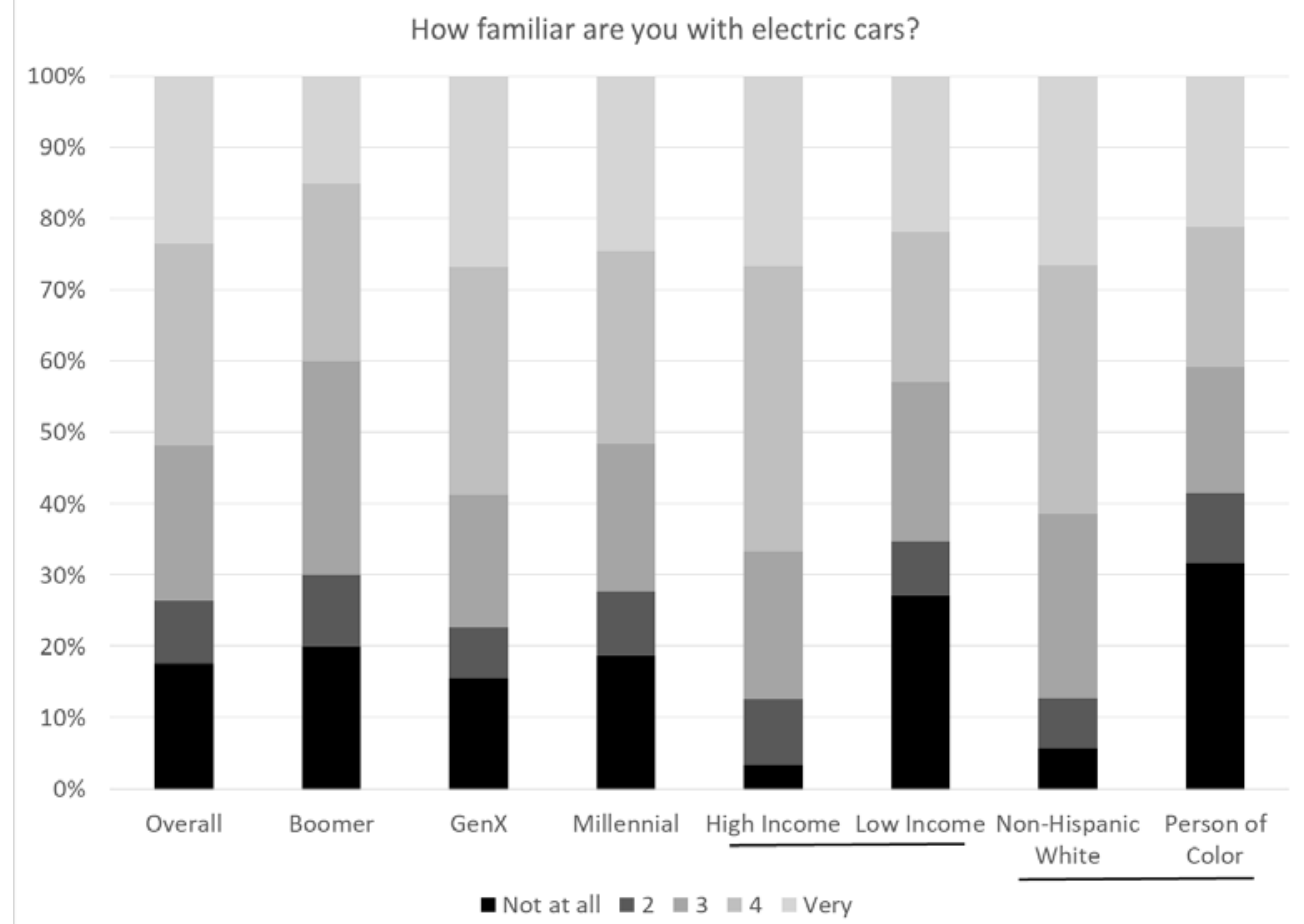

Table B24. How interested are you in owning an electric car?

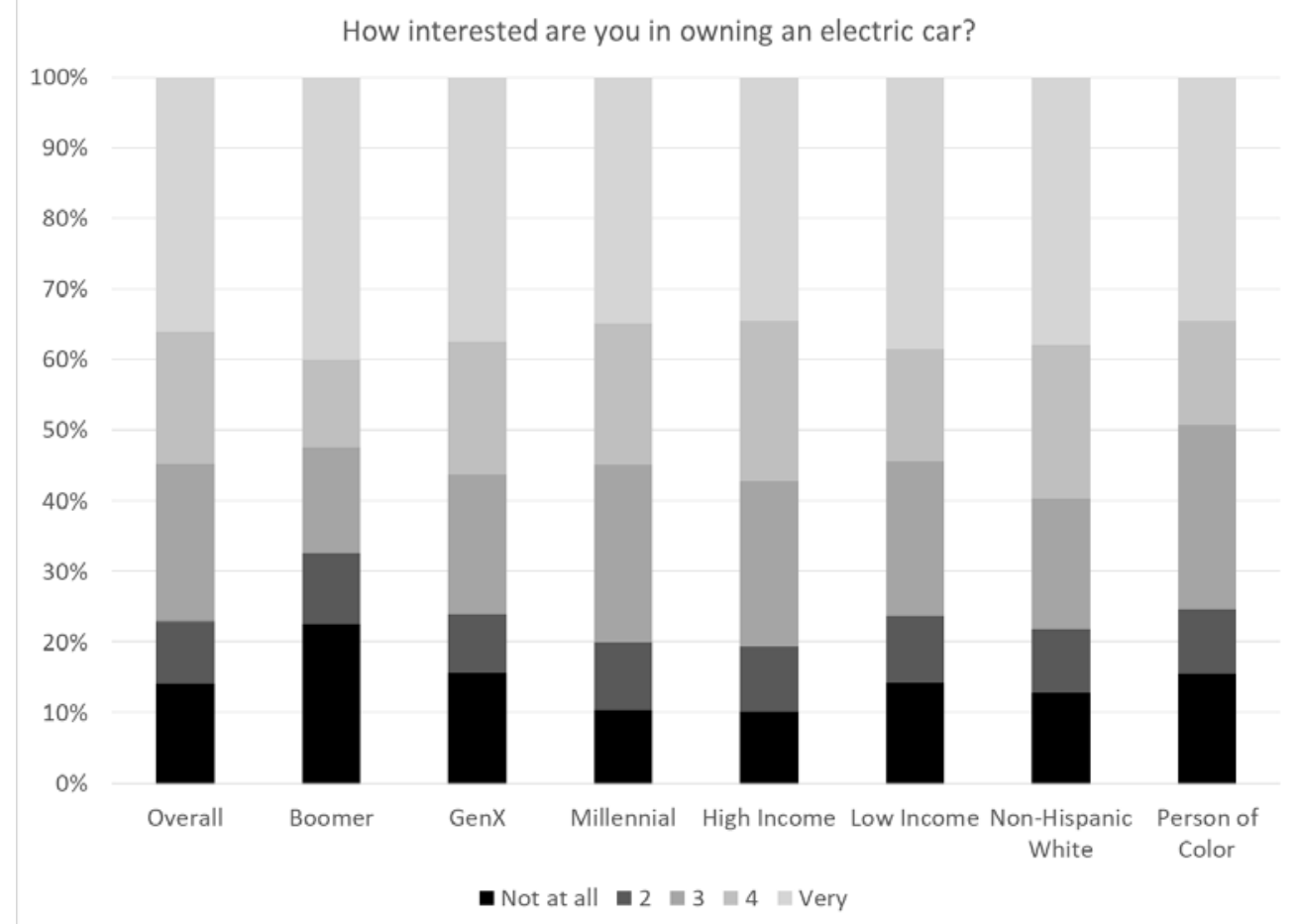


Table B25. How familiar are you with autonomous vehicles? How familiar are you with autonomous vehicles?

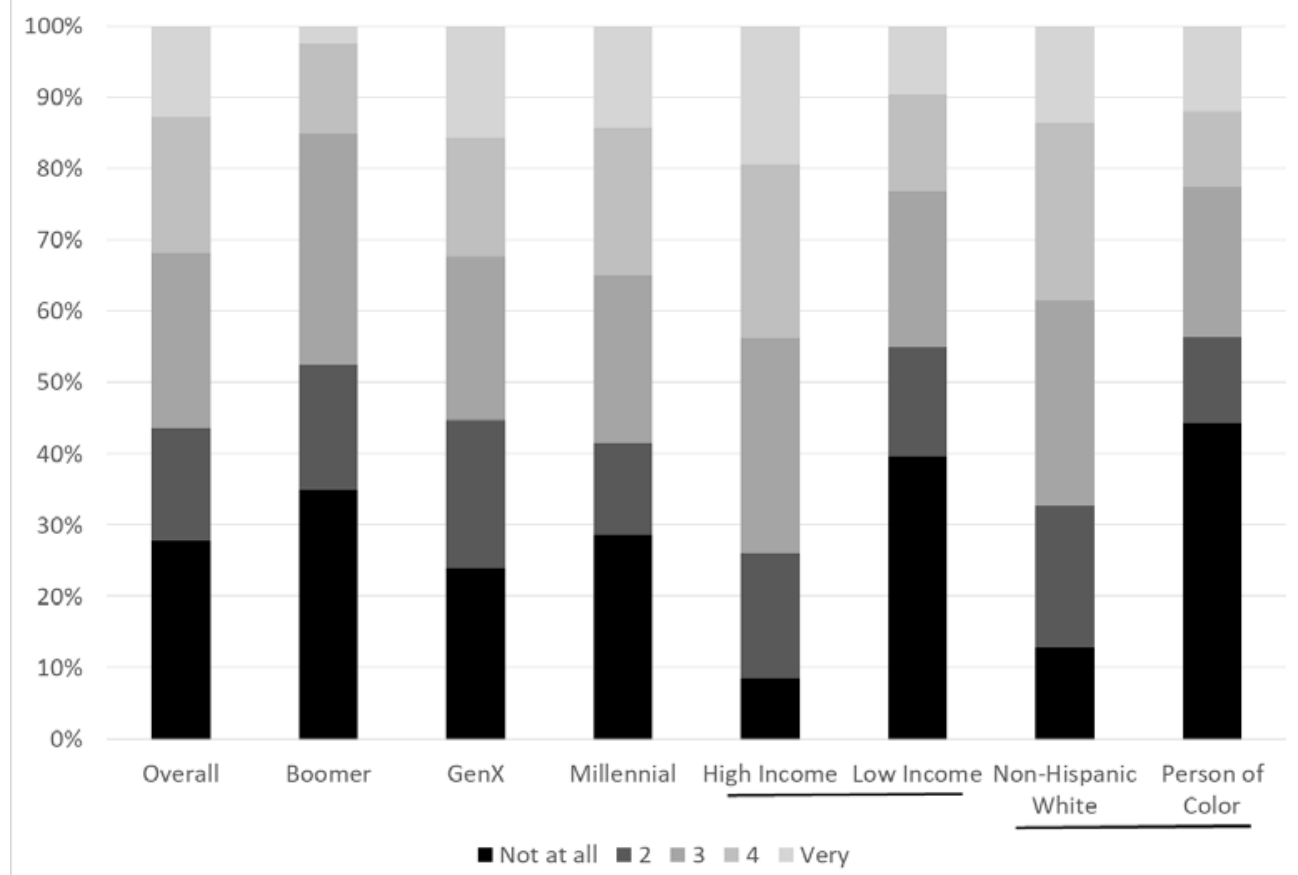

Table B26. How comfortable would you be riding in an autonomous vehicle? How comfortable would you be riding in an autonomous vehicle?

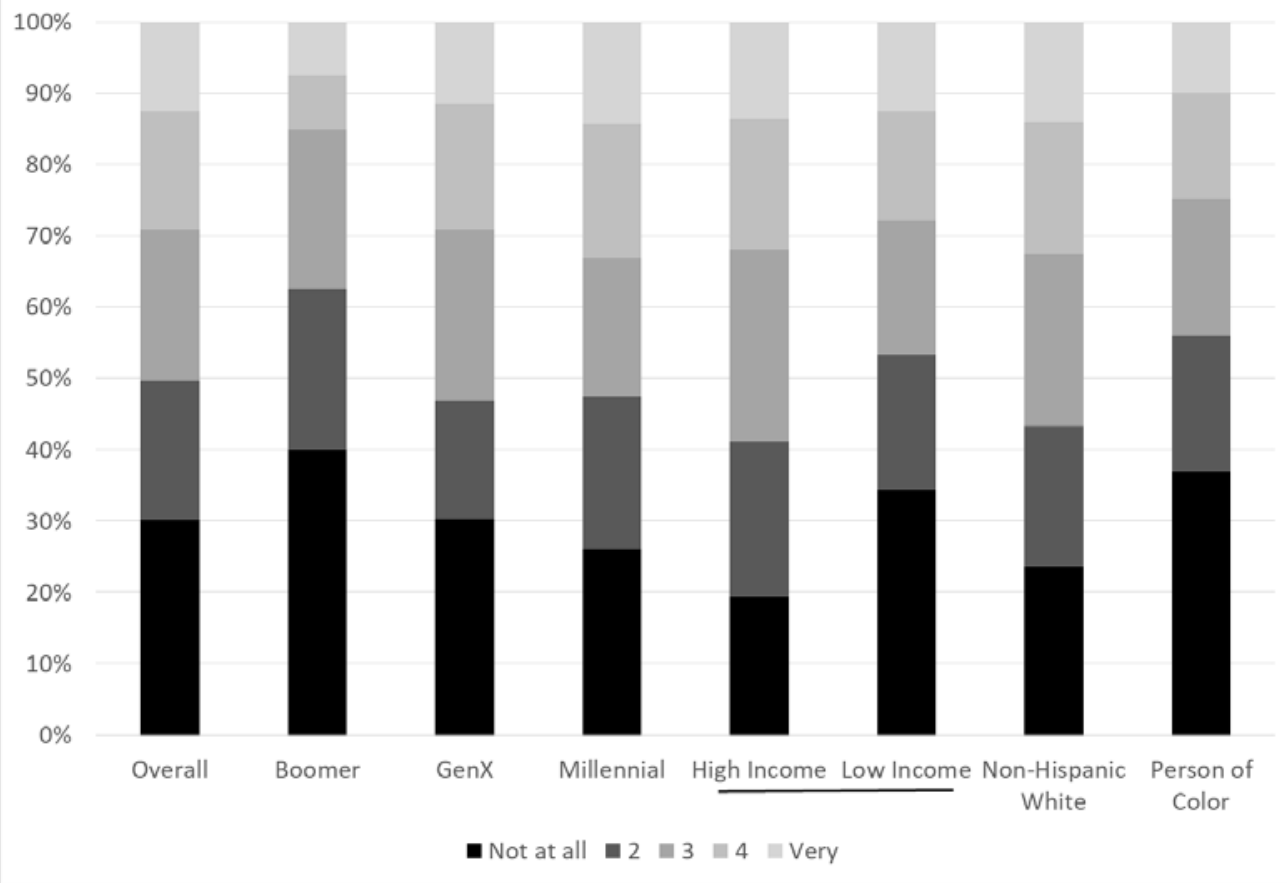


Access to data and internet

Table B27. How frequently do you use email and/or the internet?

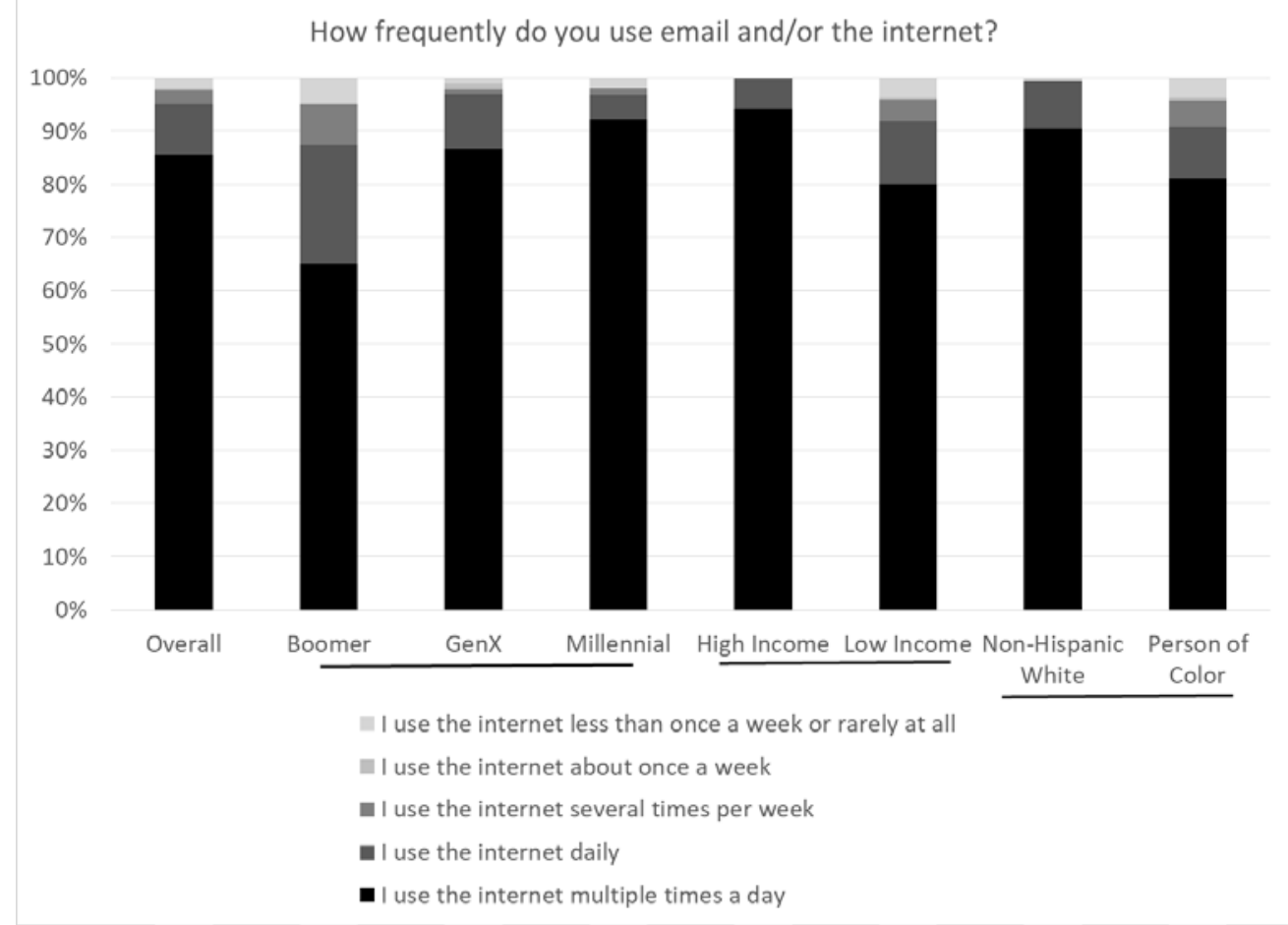

Table B28. At your home, do you have access to the internet?

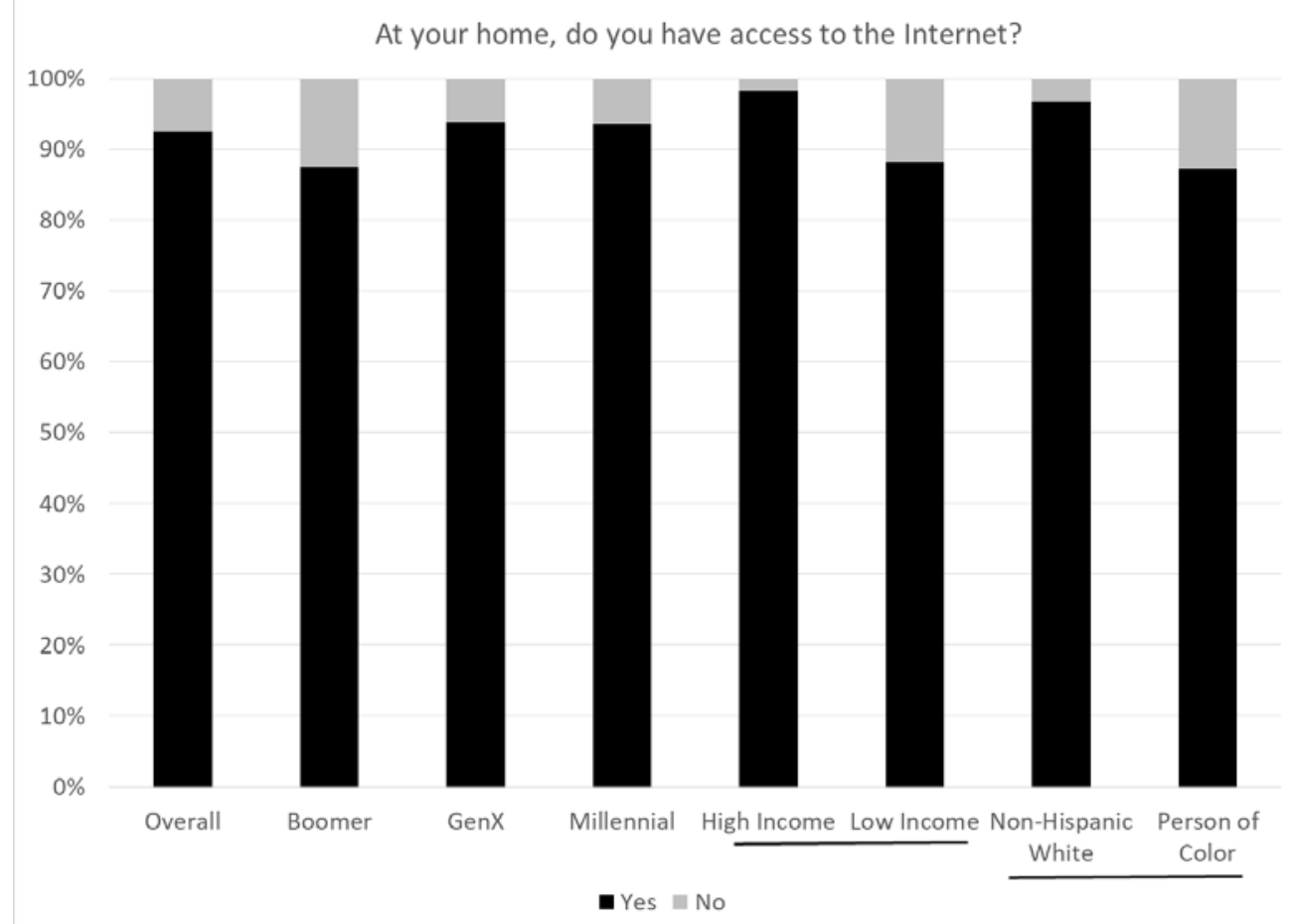


Table B29. If you work, at your workplace do you have access to the internet?

If you work, at your workplace, do you have access to the Internet?

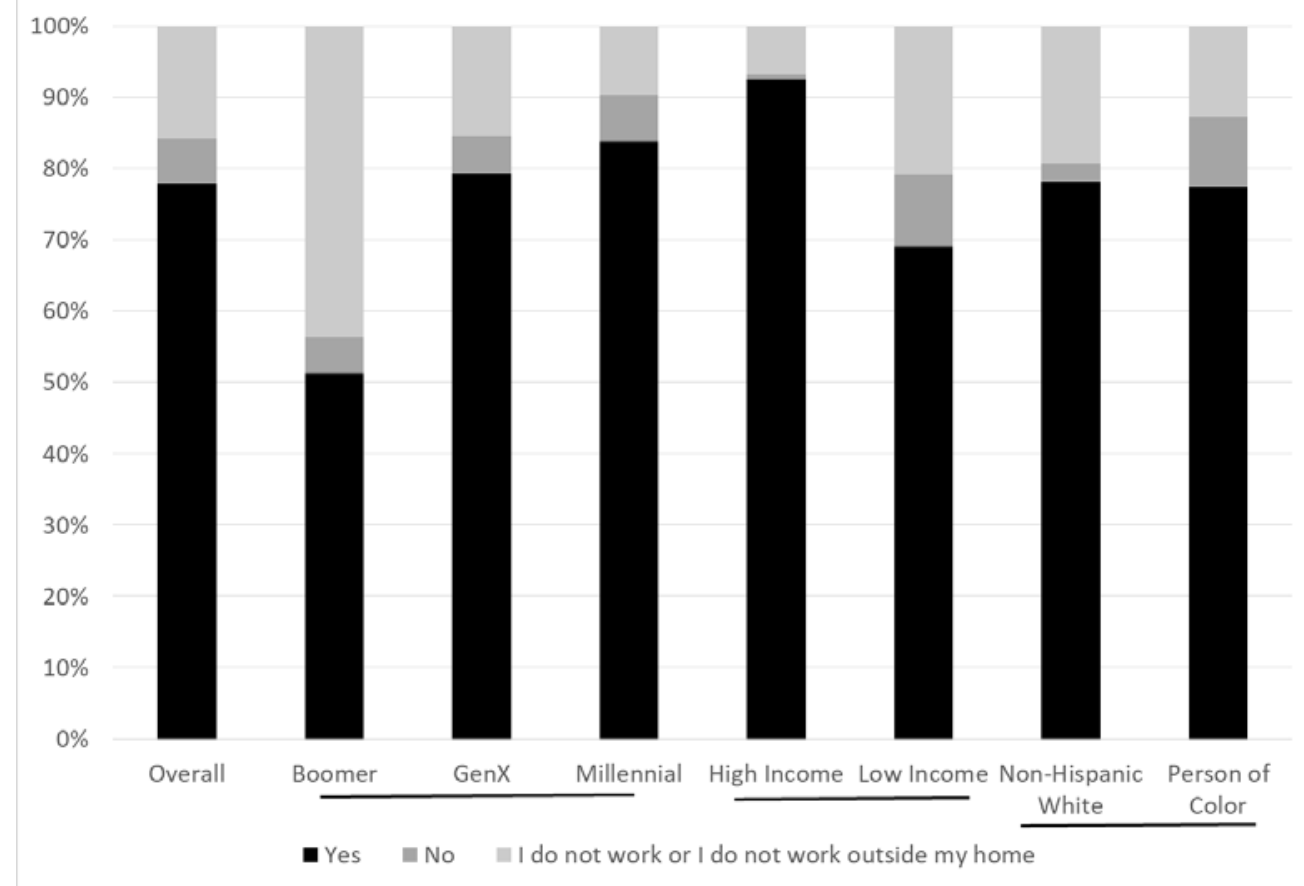

Table B30. If you have a cell phone, how frequently do you use public Wi-Fi in order to reduce your data use?

If you have a cell phone, how frequently do you use public wifi in order to reduce your data use?

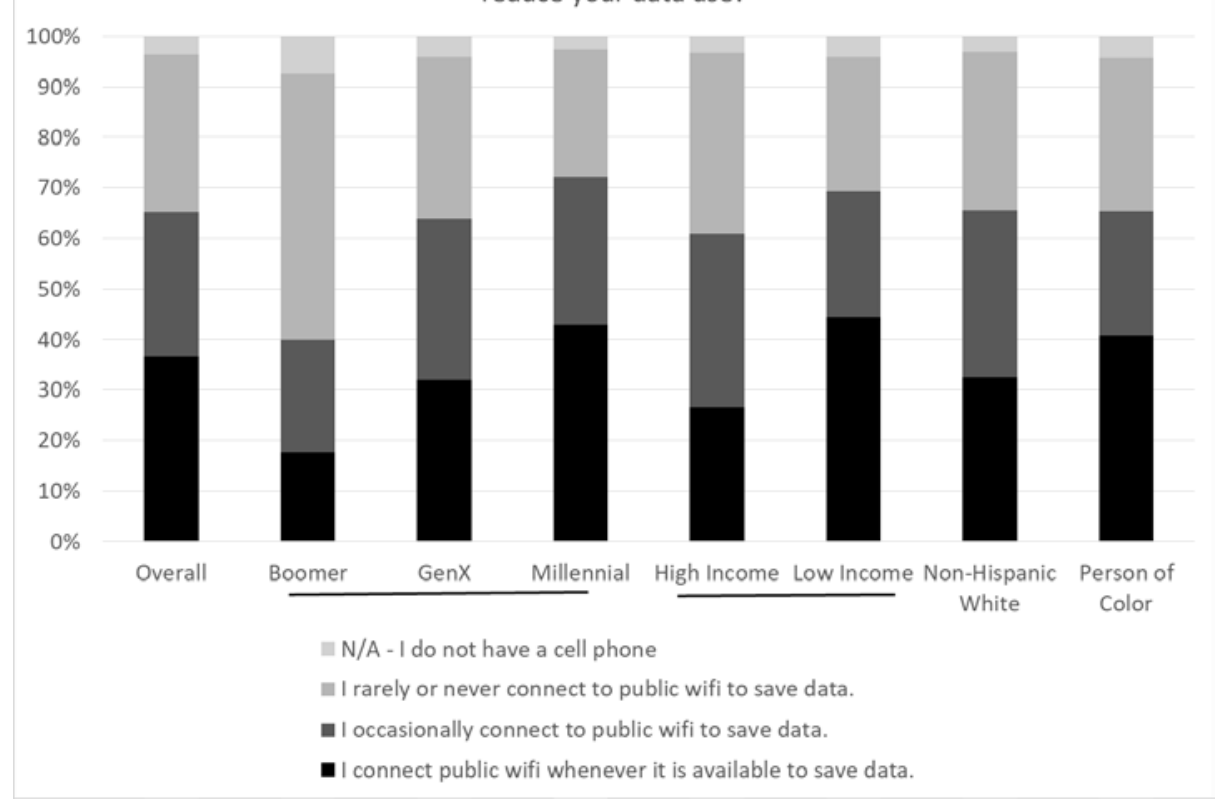


Table B31. Is your cell phone a smartphone?

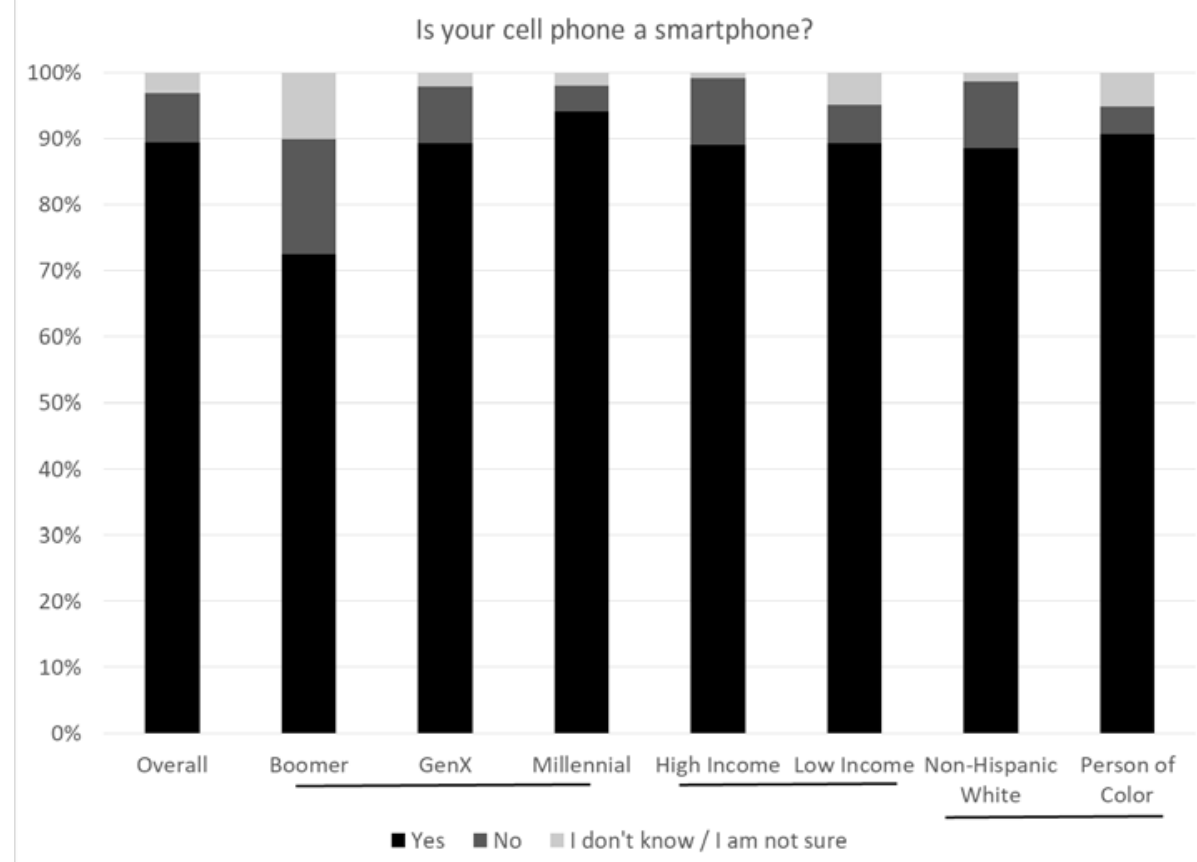

Table B32. Have you ever had to cancel your cell phone service for a period of time because of cost?

Have you ever had to cancel your cell phone service for a period of time because of cost?

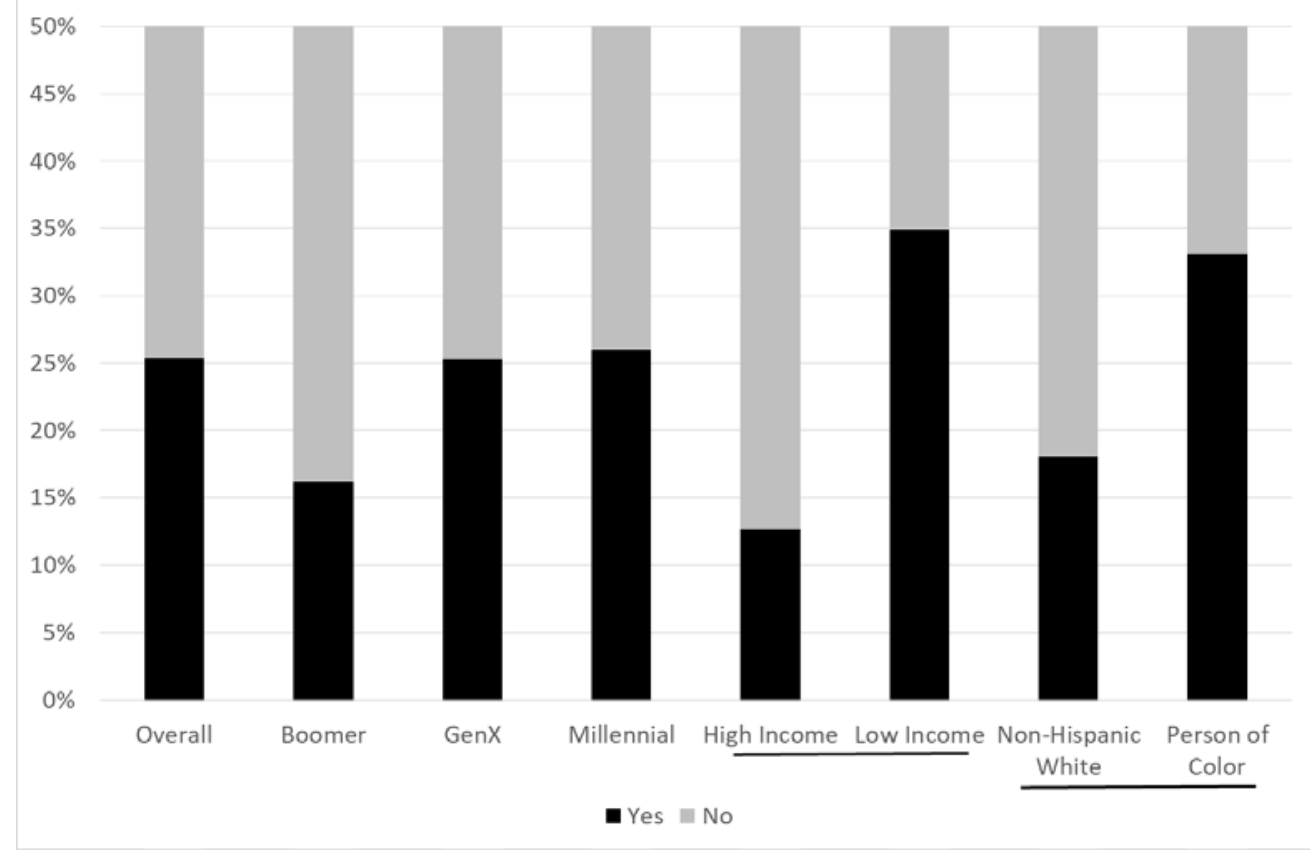


Banking and credit

Table B33. Do you have a credit card or prepaid card account?

Do you have a credit card or prepaid card account?

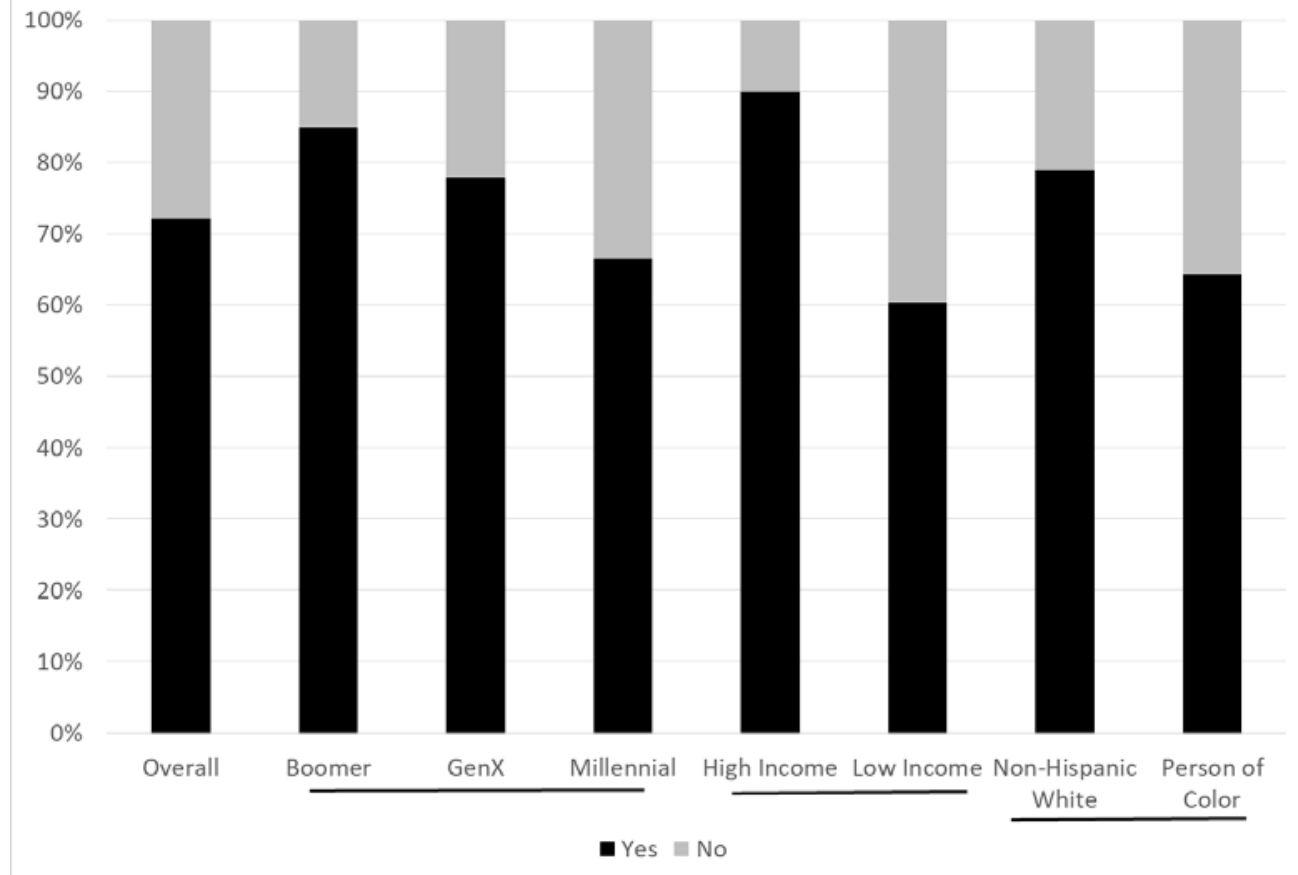

Table B34. Do you have a checking or savings account?

Do you have a checking or savings account?

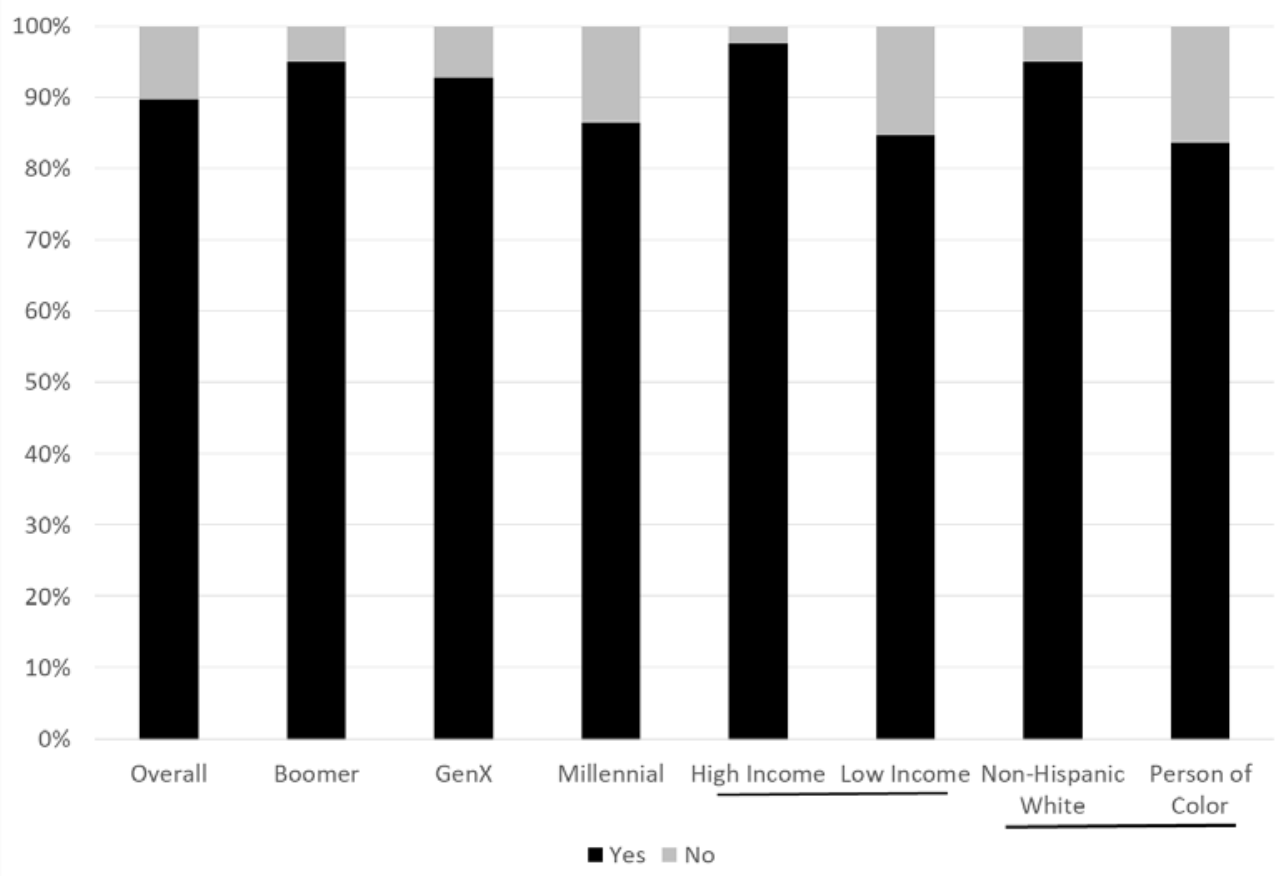


Table B35. How comfortable are you in linking your bank account or credit card to transportation apps on your phone?

How comfortable are you in linking your bank account or credit card to transportation apps on your phone?

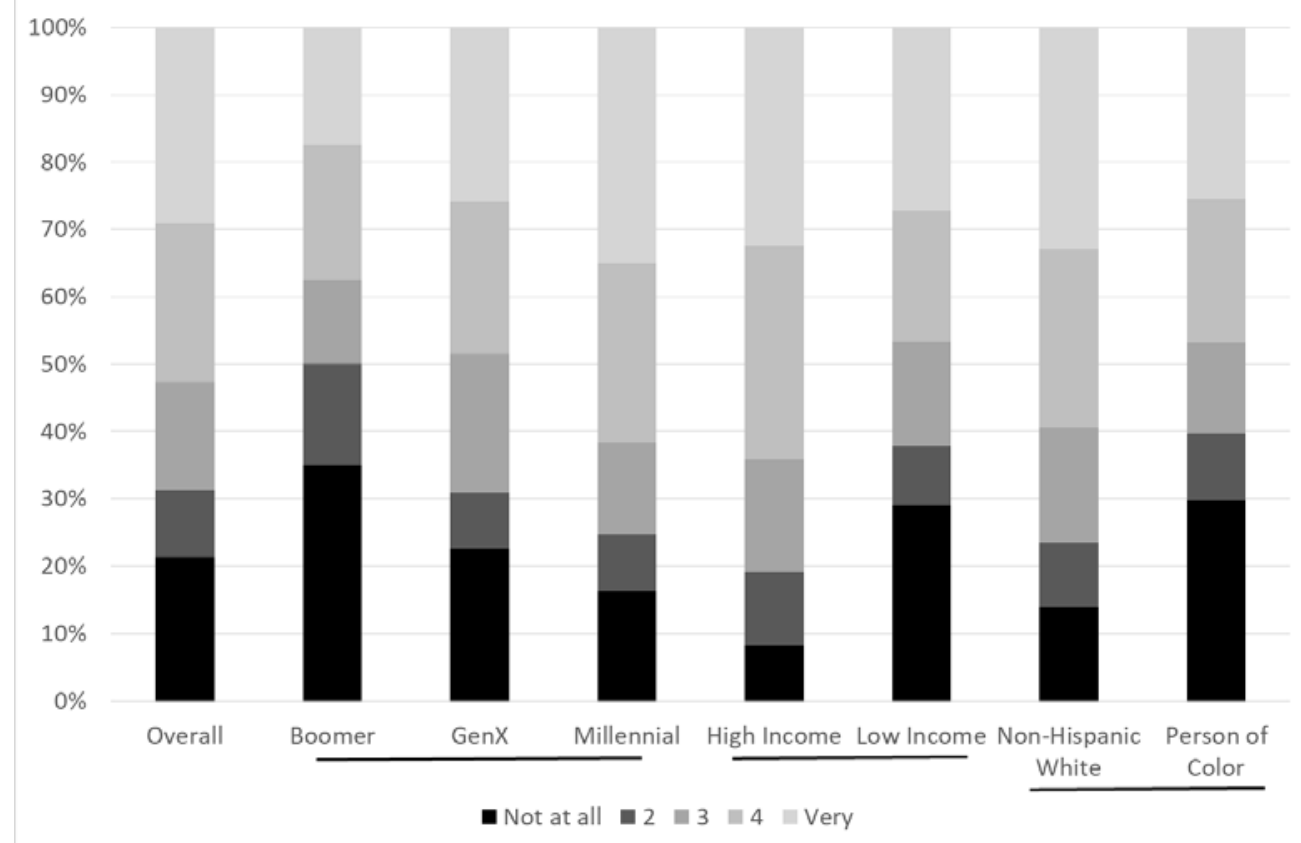


Smart mobility applications

Table B36. If you have a smartphone, how often do you use your phone to get public transportation information?

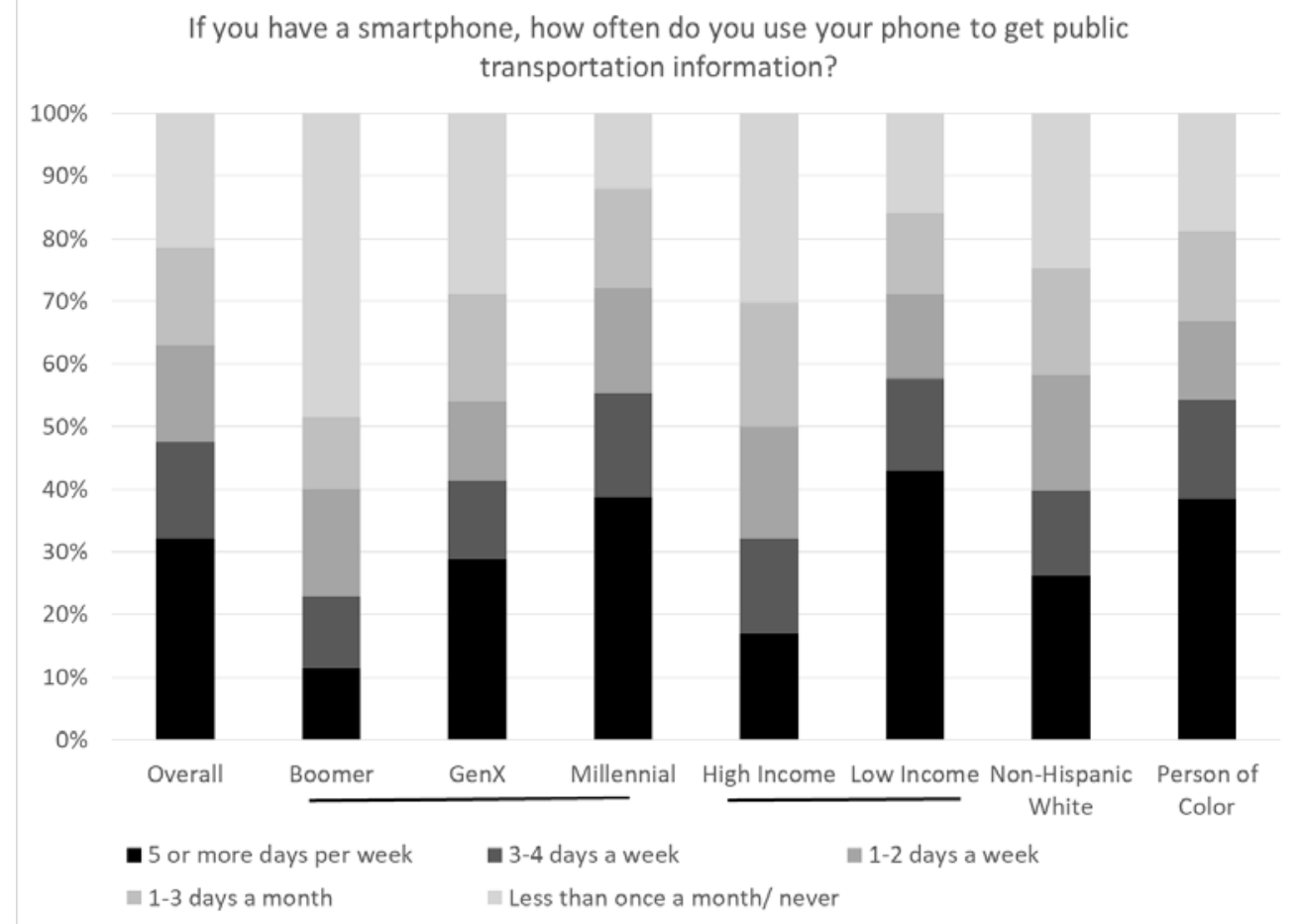

Table B37. If you have a smartphone, how often do you use your phone for navigation?

If you have a smartphone, how often do you use your phone for navigation?

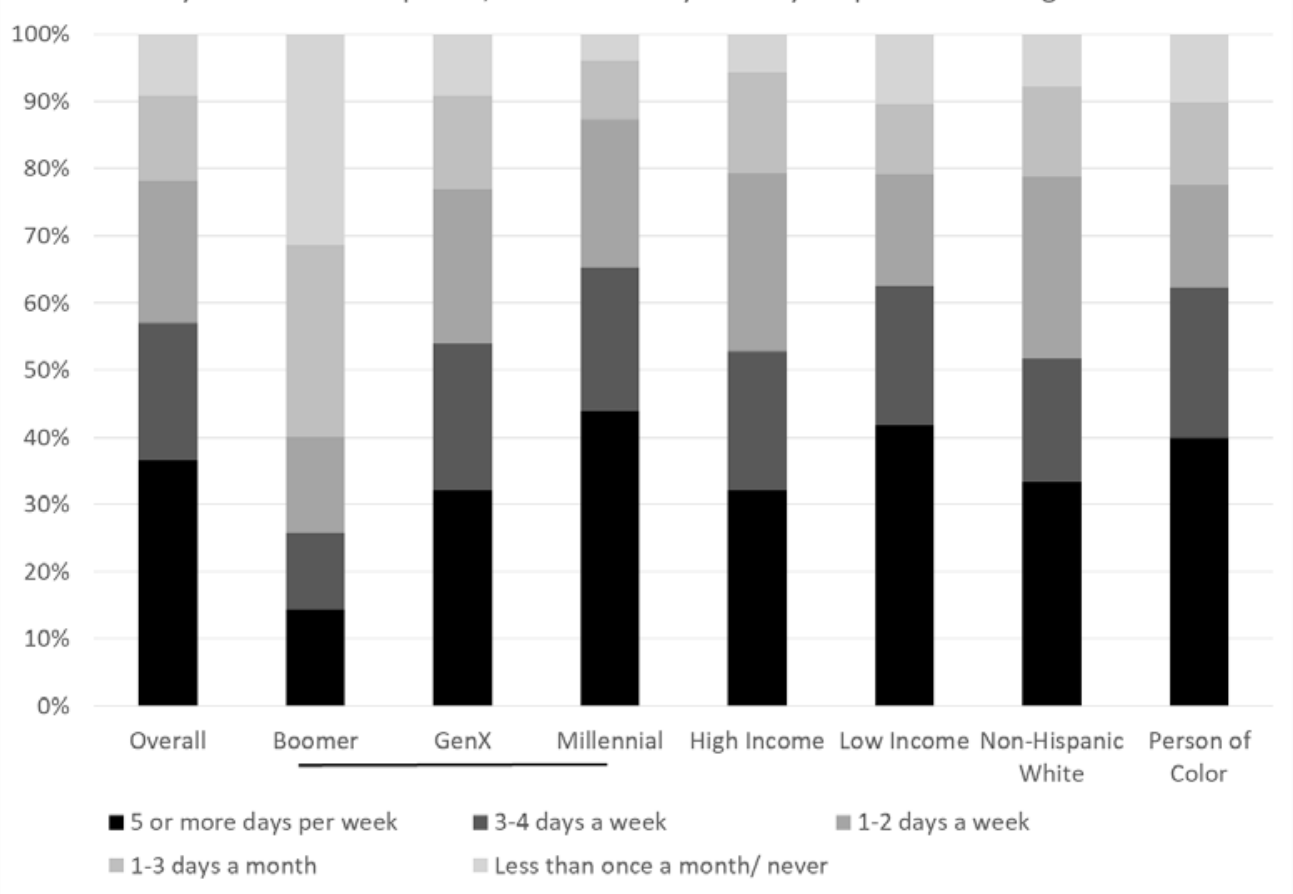


Table B38. If you have a smartphone, how often do you use your phone to reserve a ridesourcing or carsharing service?

If you have a smartphone, how often do you use your phone to reserve a ridesourcing or carsharing service?

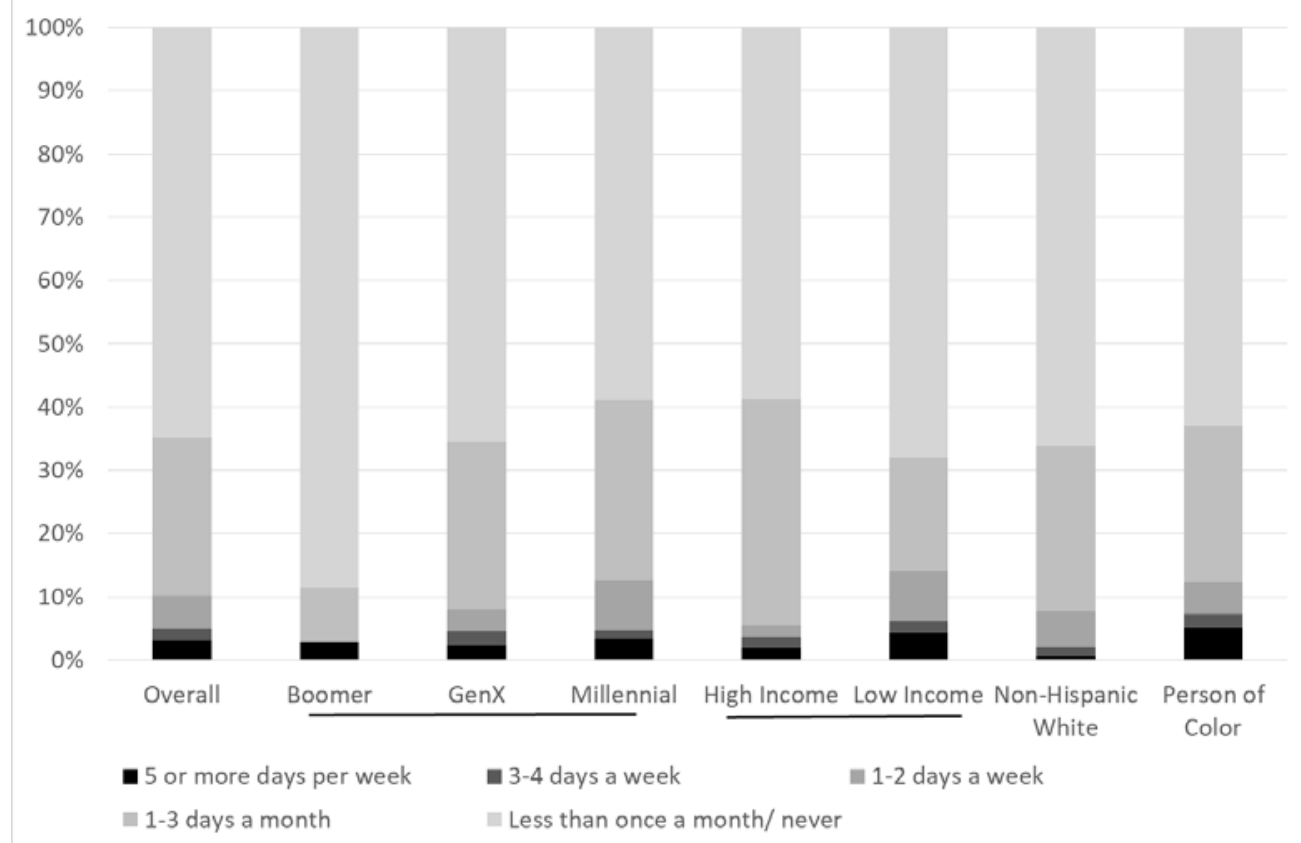

Table B39. If you have a smartphone, how often do you use your phone to use bikesharing?

If you have a smartphone, how often do you use your phone to use bikesharing?

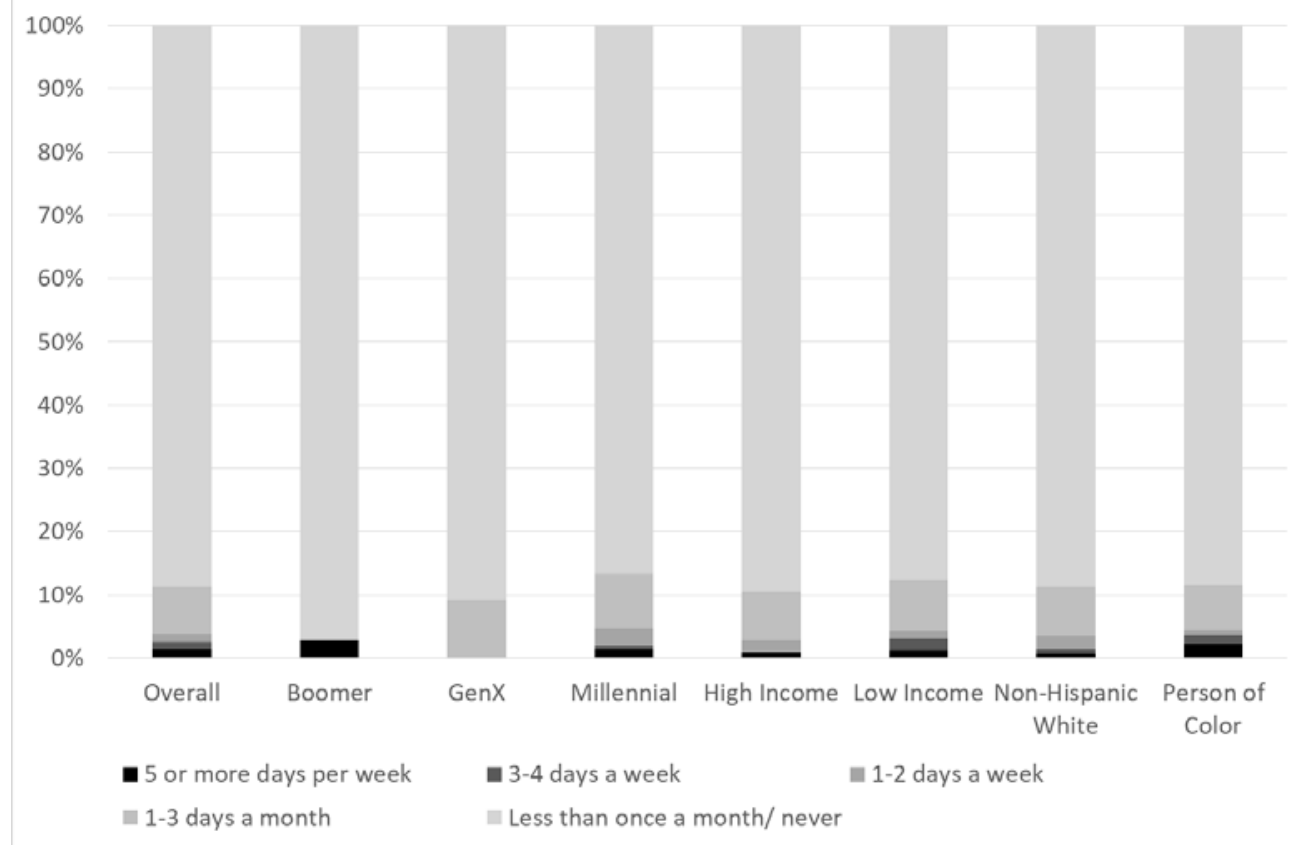


Housing and access to charging electric vehicles

Table B40. What kind of housing structure do you live in?

What kind of housing structure do you live in?

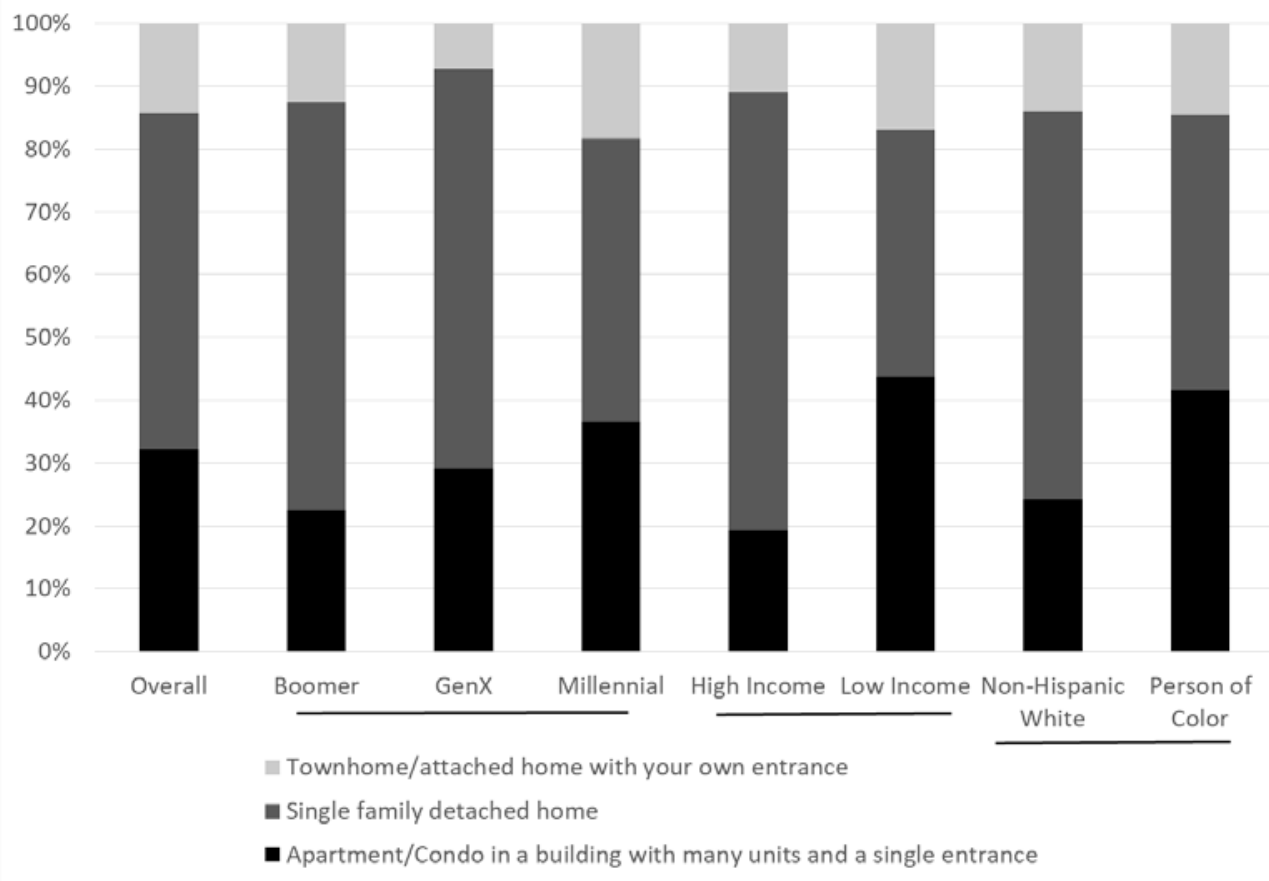

Table B41. At your home, would you be able to easily charge an electric vehicle (car or bicycle)? At your home, would you be able to easily charge an electric vehicle (car or bicycle)?

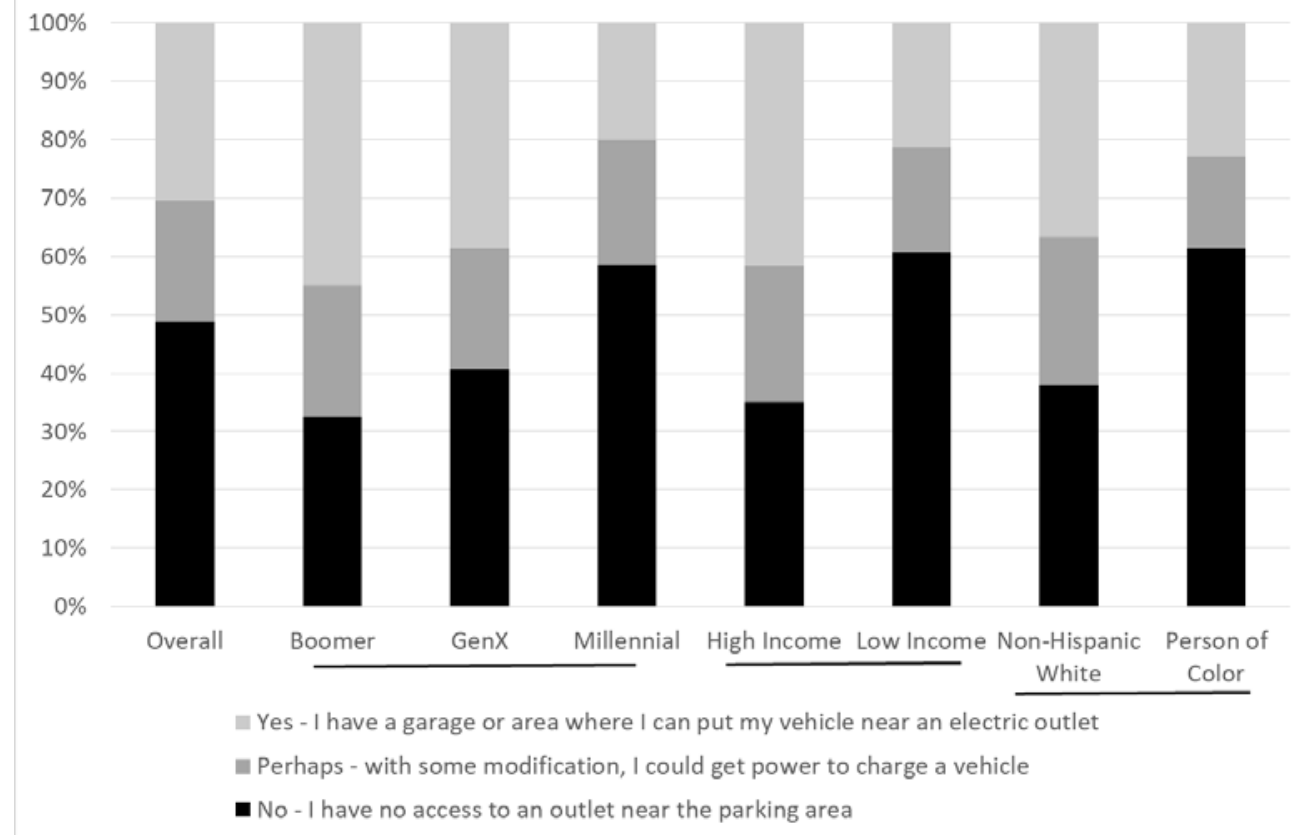




\section{RECOMMENDATIONS}

Table B42. Choose three policies (3) from the list below that you would like to see implemented:

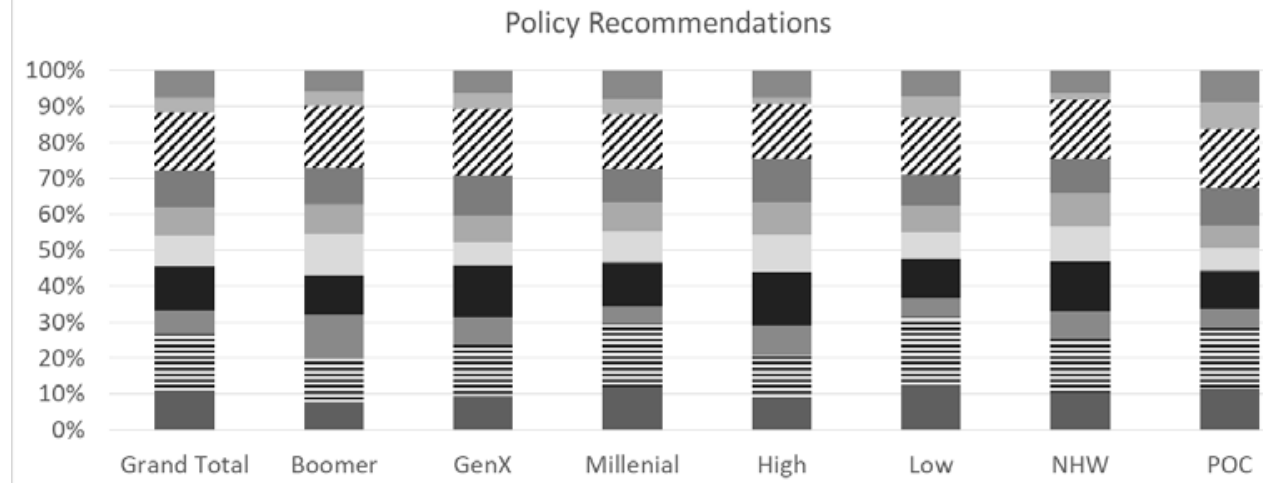

- More public outreach and education about different mobility options like car sharing, Biketown, etc.

More public outreach and education around smartphone applications for transportation services

\% Real time communication between buses and riders about crowding, arrival time, etc.

- Self-driving neighborhood shuttles to bring people to transit stops

Expansion of car sharing services that allow short-term vehicle rentals to more neighborhoods

In Expansion of the Biketown bike share program outside of central neighborhoods

- Rebates or financing to help buy clean electric vehicles

nore electric vehicle charging stations

三 Public wifi and charging stations for smartphone/mobile technology

- Smartphone applications for transportation services translated to languages other than English

Table B43. Which of the following types of neighborhood institutions or places would you most trust to gain access to information about transportation services? (Select all that apply)

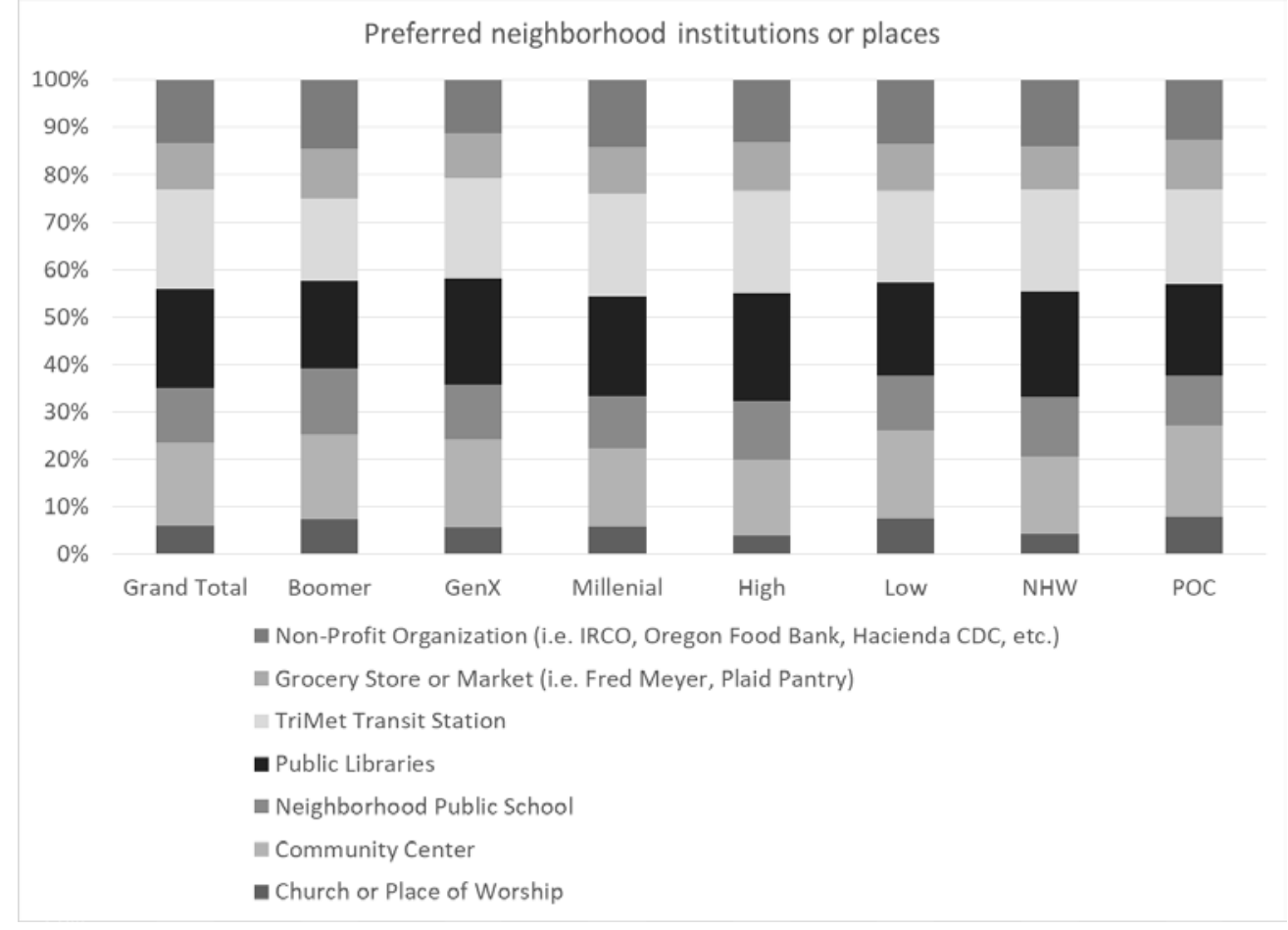


Table B44. Which of the following types of media for receiving training would you prefer? Preferred educational media

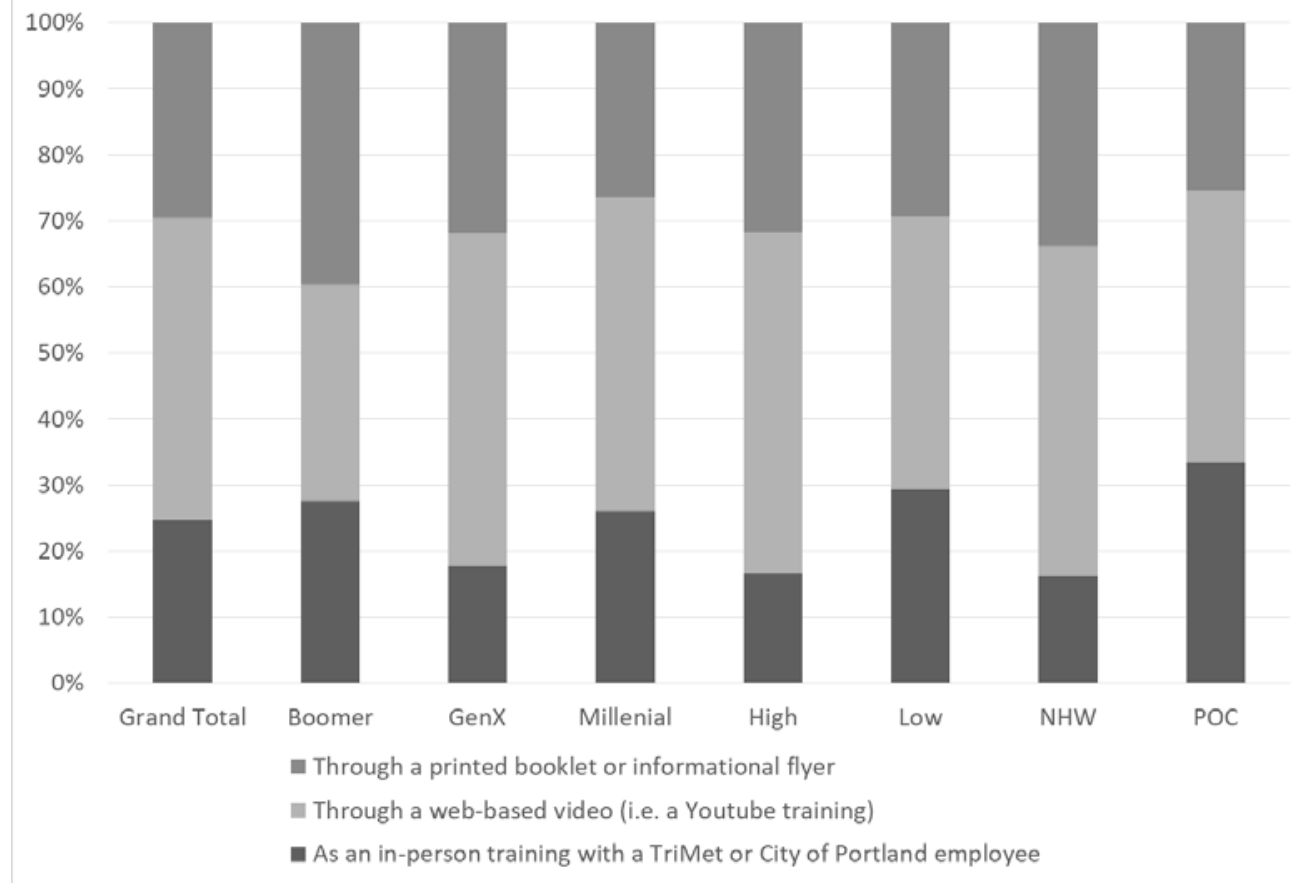




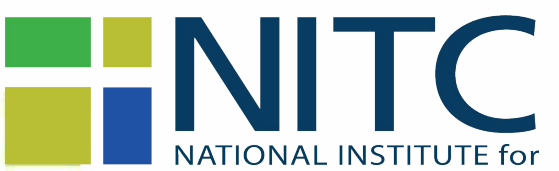

TRANSPORTATION and COMMUNITIES

Transportation Research and Education Center

Portland State University

1900 S.W. Fourth Ave., Suite 175

Portland, OR 97201 